
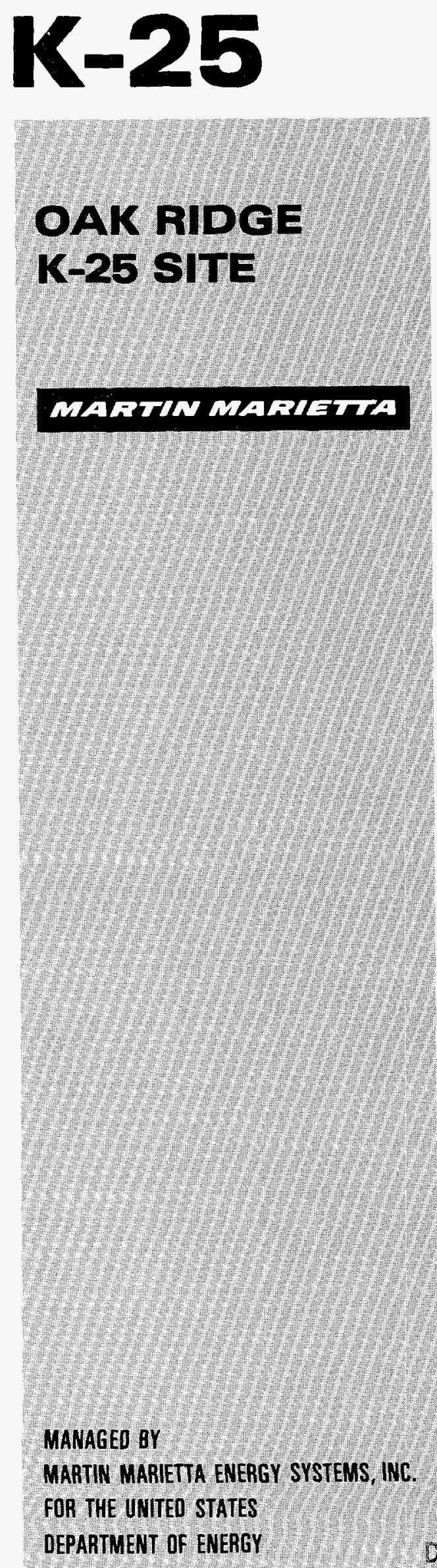


\section{DISCLAIMER}

This report was prepared as an account of work sponsored by an agency of the United States Government. Neither the United States Government nor any agency thereof, not any of their employees, makes any warranty, express or implied, or assumes any legal liability or responsibility for the accuracy, completeness, or usefulness of any information, apparatus, product, or process disclosed, or represents that its use would not infringe privately owned rights. Reference herein to any specific commercial product, process, or service by trade name, trademark, manufacturer, or otherwise, does not necessarily constiture or imply its endorsement, recommendation, or favoring by the United States Government or any agency thereof. The views and opinions of authors expressed herein do not necessarily state or reflect those of the United States Government or any agency thereof. 


\section{DISCLAMMER}

Portions of this document may be illegible in electronic image products. Images are produced from the best available original document. 
Health and Safety Upgrades Program

Oak Ridge K-25 Site

\title{
LIFE CYCLE COST ANALYSIS \\ FOR REPLACEMENT OF FLUORESCENT LIGHT FIXTURES CONTAINING POLYCHLORINATED BIPHENYLS
}

\author{
Prepared by \\ Science Applications International Corporation \\ 800 Oak Ridge Turnpike, Suite 1000 \\ Oak Ridge, Tennessee 37830 \\ Under Subcontract 95B-99928, Letter Release K30
}

Date Issued-April 29, 1992

\author{
Prepared for \\ Health and Safety Upgrades Program \\ Engineering Division \\ at the \\ Oak Ridge K-25 Site \\ Oak Ridge, Tennessee 37831-7101 \\ managed by \\ MARTIN MARIETTA ENERGY SYSTEMS, INC. \\ for the \\ U.S. DEPARTMENT OF ENERGY \\ under contract DE-AC05-84OR21400




\section{LIFE CYCLE COST ANALYSIS \\ FOR REPLACEMENT OF FLUORESCENT LIGHT FIXTURES \\ CONTAINING PCBS AT THE K-25 SITE \\ TABLE OF CONTENTS}

Page

EXECUTIVE SUMMARY $\ldots \ldots \ldots \ldots \ldots \ldots \ldots \ldots$ iv

PRINCIPAL DEFINITIONS $\ldots \ldots \ldots \ldots \ldots \ldots \ldots \ldots$ vii

ACRONYMS $\ldots \ldots \ldots \ldots \ldots \ldots \ldots \ldots \ldots \ldots \ldots \ldots \ldots \ldots \ldots \ldots$

1.0 STUDY DEFINITION AND REFERENCES $\ldots \ldots \ldots \ldots \ldots \ldots \ldots$

$1.1 \quad$ Background $\ldots \ldots \ldots \ldots \ldots \ldots \ldots \ldots \ldots \ldots \ldots$

1.2 Applicable Regulations and References . . . . . . . . . . . . 1

2.0 TOTAL LIFE-CYCLE COST (TLCC) ESTIMATING APPROACH $\ldots \ldots \ldots \ldots$

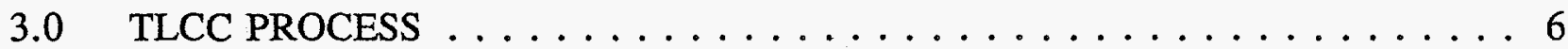

3.1 Definition of Assumptions and Guidelines . . . . . . . . . 6

3.1.1 Constant Dollars . . . . . . . . . . . . . . . 6

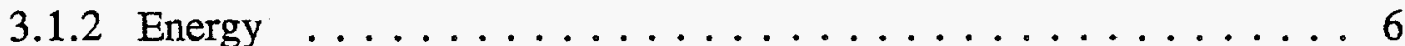

3.1 .3 Investment Costs $\ldots \ldots \ldots \ldots \ldots \ldots \ldots$

3.1.4 Annually Recurring Operating and Maintenance Costs . . . . . . 7

3.1.5 Non-Annually Recurring Repairs and Replacement

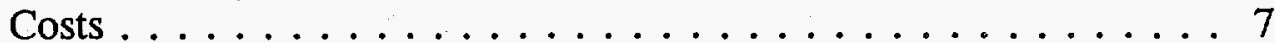

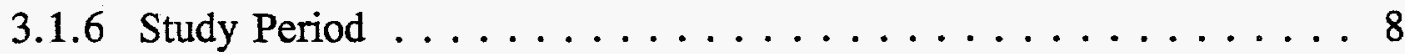

3.1.7 Determination of Project Cost Effectiveness . . . . . . . . 8

3.2 Data Criteria and Analysis $\ldots \ldots \ldots \ldots \ldots \ldots \ldots \ldots$

3.3 TLCC Modes of Analysis . . . . . . . . . . . . . 12

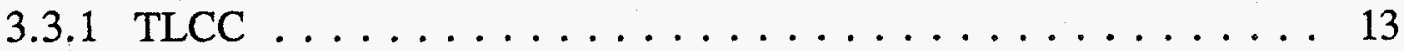

3.3 .2 Net Savings (NS) $\ldots \ldots \ldots \ldots \ldots \ldots \ldots \ldots \ldots$

3.3.3 Saving-To-Investment Ratio (SIR) $\ldots \ldots \ldots \ldots \ldots \ldots \ldots 14$

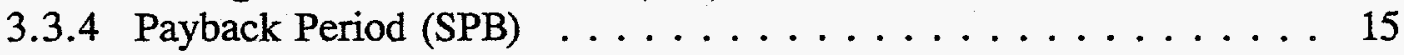


TABLE OF CONTENTS (Continued)

$\underline{\text { Page }}$

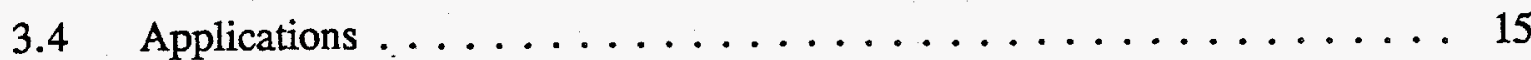

3.4.1 Determining Cost Effectiveness . . . . . . . . . . 15

3.4 .2 Time Value of Monies . . . . . . . . . . . . 16

4.0 DEFINITIONS OF BASELINE AND ALTERNATIVE CASES $\ldots \ldots \ldots \ldots \ldots$

$4.1 \quad$ Baseline Case . . . . . . . . . . . . . . . 18

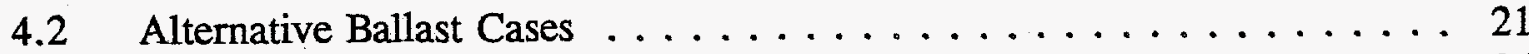

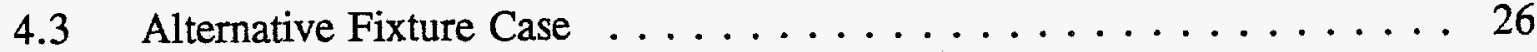

$5.0 \quad$ TLCC ANALYSIS RESULTS $\ldots \ldots \ldots \ldots \ldots \ldots \ldots \ldots \ldots \ldots$

5.1 Comparison of Alternative Systems . . . . . . . . . . . . . 28

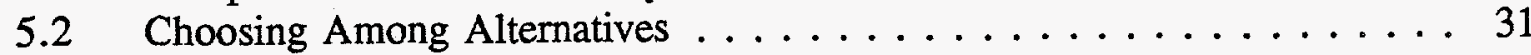

5.3 Recommendations . . . . . . . . . . . . . . 35

APPENDIX A - COSTING OF BULB ONLY CHANGE-OUT

APPENDIX B - ALTERNATIVE BALLAST COST DATA

APPENDIX C - COST OF TOTAL FIXTURE CHANGE-OUT 


\section{EXECUTIVE SUMMARY}

A Life-Cycle Cost Analysis was performed on fluorescent light ballasts to be used as replacements for ballasts containing PCBs at the Martin Marietta Energy Systems K-25 Site. A broad sample (12) of commercially available fluorescent ballasts was selected for the analysis. Only ballasts that were found to be in compliance with applicable performance regulations, mandated by Federal government were studied. The sampling included electromagnetic, electromagnetic/electronic (hybrid) and electronic type ballasts. In lieu of only changing out ballasts, an alternative case of changing out the total fixtures was also considered. Since the best performing ballast was identified in previous case studies, the fixture scenario used fixtures equipped with the best performing ballast. The National Bureau of Standards Building Life Cycle Cost (BLCC) computer program was used to compare the performance of the 12 ballasts and fixtures to the existing lighting systems. Investment costs of material and labor, operating and maintenance costs, replacement costs including clean up of leaky ballasts, and lighting energy costs were considered for study periods of 5, 10, 15, 20, and 25 years; and lighting duty cycles of $3,000,4,000$, and 6,000 hours per year using both standard and energy efficient bulbs were used. The life cycle program costs were entered in constant dollars with the federally mandated discount rate of $4.6 \%$ and DOE escalation rate for future energy costs. Thus, resulting life cycle costs are in Present Value dollars to permit a normalized basis for comparison.

The alternative Total Life Cycle Cost runs produced the following results:

1. There was a ballast that consistently proved to be the most cost effective under all study variables. This was an electromagnetic/electronic hybrid ballast with low initial cost and high energy savings. The unit is Magnetek model Universal Plus.

2. The lowest life cycle cost for each ballast was obtained using energy efficient bulbs. 
3. The Life Cycle Cost Analysis shows that when using the ballast with the lowest life cycle cost in the proposed Remediation Plan for replacing ballasts containing PCBs at the K-25 site, a break-even period from seven to eight years is obtained. Not only will compliance with the EPA requirements for removing the PCB-laden ballasts be obtained, but the energy savings from using this ballast and avoided cleanup costs will provide a payback within seven to eight years plus additional savings over its 25 year life.

4. If the Magnetek ballast model "Universal Plus" is used in the ballast change-out, the following net savings will be realized over the existing conditions:

\begin{tabular}{||c|c|c|c|c|c|c||}
\hline \multicolumn{7}{|c|}{$\begin{array}{c}\text { NET SAVINGS (\$1000) } \\
\text { Ballast Change-out }\end{array}$} \\
\hline \hline \multirow{2}{*}{$\begin{array}{l}\text { Duty Cycle } \\
\text { Hours/Year }\end{array}$} & \multicolumn{6}{|c||}{ Time (Years) } \\
\cline { 2 - 8 } & 5 & 7 & 10 & 15 & 20 & 25 \\
\hline \hline 3000 & $-\$ 3635$ & $-\$ 125$ & $\$ 2748$ & $\$ 4894$ & $\$ 4996$ & $\$ 5054$ \\
\hline 4000 & $-\$ 3425$ & $-\$ 124$ & $\$ 2988$ & $\$ 5502$ & $\$ 5627$ & $\$ 5758$ \\
\hline 6000 & $-\$ 3303$ & $\$ 1359$ & $\$ 4200$ & $\$ 6133$ & $\$ 4404$ & $\$ 4674$ \\
\hline
\end{tabular}

5. If fixtures containing Magnetek ballast model Universal Plus and energy efficiency bulbs were used to reflect a total fixture change-out as a defined plan, the total life cycle costs are greater than the ballast change-out as defined plan. Basically material costs of fixtures are greater than ballasts. The net savings of the defined fixture change-out plan are shown in the following chart. The payback period shifts from approximately seven years for a defined ballast change-out plan to slightly less than 10 years for the defined fixtures change-out plan. 


\begin{tabular}{||c|c|c|c|c|c|c|}
\hline \multicolumn{7}{|c|}{$\begin{array}{c}\text { NET SAVINGS (\$1000) } \\
\text { Fixture Change-out }\end{array}$} \\
\hline $\begin{array}{l}\text { Duty Cycle } \\
\text { Hours/Year }\end{array}$ & 5 & 7 & 10 & 15 & 20 & 25 \\
\hline 4000 & $-\$ 5401$ & $-\$ 2275$ & $\$ 763$ & $\$ 2966$ & $\$ 2849$ & $\$ 2768$ \\
\hline
\end{tabular}




\section{PRINCIPAL DEFINITIONS ${ }^{1}$}

Annually Recurring Costs. Those costs which are incurred each year in an equal, constant dollar amount throughout the Study Period.

Annual Value (Annual Worth). Project costs or benefits amortized over the Study Period; that is, expressed as an annually recurring uniform amount, taking into account the Time Value of Money.

Ballast Efficacy Factor. The relative light output divided by the power input of a fluorescent lamp ballast as measured under test conditions of ANSI Standard C 82.2-1984. BEF equals relative light output divided by power input.

Ballast Factor. The relative light output of a ballast divided by the light output of an ANSI standard reference ballast expressed as percent.

Base Case. The situation against which an Alternative Building System is compared.

Base Year. The first year of the study period, generally the year in which the life-cycle cost analysis is conducted.

Base-Year Energy Costs. The quantity of energy delivered to the boundary of a Federal Building in the Base Year, multiplied by the Base-Year Price of fuel.

Base-Year Energy Savings. For an Existing Federal Building, the positive difference between the existing building's Base-Year Energy Costs before the Retrofit and its estimated Base-Year Energy Costs after the Retrofit of a proposed Alternative Building System, taking into account

${ }^{1}$ Definitions are from Life-Cycle Cost Manual for Federal Energy Management Program unless otherwise noted. 
all types of energy affected. For a New Federal Building, the positive difference between the estimated Base-Year Energy Cost of a building design or Building System design which is not primarily oriented towards energy conservation and the estimated Base-Year Energy Cost of an alternative building design or Building System design, taking into account all types of energy affected.

Base-Year Price. The price of a good(s) or service(s) as of the beginning of the first year of the study period.

Building. Any structure with a roof and walls designed for storage or human use.

Building System. A portion of the structure of the Building or of any energy-using system in the Building.

Cash Flow. The stream of costs and benefits (expressed for the purpose of this requirement in Constant Dollars) resulting from a project investment.

Constant Dollars. Dollars of uniform purchasing power tied to a reference year (usually the Base Year) and exclusive of general price inflation or deflation.

Cost Effective. The condition whereby an Alternative Building System saves more than it costs over the Study Period, where all Cash Flows are assessed in Constant Dollars and discounted to reflect the Time Value of Money.

Current Dollars. Dollars of nonuniform purchasing power, including general price inflation or deflation, in which actual prices are stated. (With zero inflation or deflation, current dollars are identical to constant dollars.) 
Demand Charge. That portion of the charge for electric service based on the plant and equipment costs associated with supplying the electricity consumed.

Differential Cost. The difference in the costs of an Alternative Building System and the Base Case.

Differential Energy Price Escalation Rate. The difference between a projected general rate of inflation and the projected rate of price increase assumed for energy.

Discount Factors. Multiplicative numbers used to convert Cash Flows occurring at different times to correspond at a common time. Discount factors are obtained by solving Discount Formulas based upon one dollar of value and an assumed Discount Rate and Time.

Discount Rate. The rate of interest, reflecting the investor's Time Value of Money (or opportunity cost), that is used in Discount Formulas or to select Discount Factors which in turn are used to convert ("discount") Cash Flows to a common time. Real discount rates reflect time value apart from changes in the purchasing power of the dollar and are used to discount constant dollar cash flows; nominal discount rates include changes in the purchasing power of the dollar and are used to discount current dollar cash flows.

Discounted Payback Period. The time required for the cumulative savings from an investment to payback the Investment Costs and other accrued costs, taking into account the Time Value of Money.

Discounting. A technique for converting Cash Flows occurring over time to time-equivalent values, adjusting for the Time Value of Money. 
Energy Conservation Measure. An installation or modification of an installation in a building which is primarily intended to reduce energy consumption cost, or allow the use of a renewable energy source.

Existing Federal Building. A Federal Building, the construction of which was completed by November 9, 1978, or the design of which cannot feasibly be modified after the effective date of Subpart C of Part 436, 10 CFR.

Facility. Any group of closely located Buildings, none of which is individually metered for all energy sources and for which the actual rate of use of all energy sources can be determined.

Federal Building. Any Building, structure, or facility which is constructed, renovated, leased or purchased in whole or in part for use by the United States, and which includes a heating system, or cooling system, or both.

Inflation. A rise in the general price level, or a decline in the general purchasing power of the dollar.

Internal Rate of Return. The compound rate of interest which, when used to discount Cash Flows of an Alternative Building System, will result in zero Net Savings (Net Benefits).

Investment Costs. The initial costs of design, engineering, purchase and installation, exclusive of "Sunk Costs," all of which are assumed to occur as a lump sum at the beginning of the Base Year for purposes of making the life-cycle cost analysis.

Life-Cycle Costing (LCC). A method of economic evaluation that sums discounted dollar costs of initial investment (less Salvage Value), replacements, operations (including energy usage), and maintenance and repair of a Building or Building System over the Study Period (see Total LifeCycle Cost). Also, as used in this report, a general approach to economic evaluation 
encompassing several related economic evaluation techniques, or "Modes of Analysis," including Total Life-Cycle Cost Analysis, Net Benefits or Net Savings Analysis, Savings-to-Investment Ratio Analysis, and Internal Rate of Return Analysis, all of which take into account long-run dollar impacts of a project.

Modes of Analysis. The various ways in which project cash flows can be combined and presented to describe a measure of project cost effectiveness. The Modes of Analysis used to evaluate FEMP projects are Total Life-Cycle Costs (TLCC), Net Savings (NS), and Savings-toInvestment Ratio (SIR). Simple Payback (SPB), a Mode of Analysis not fully consistent with the LCC method, is used as a supplemental measure for solar energy projects because of a specific legislative requirement.

Net Savings (Net Benefits). Time-adjusted savings (or benefits) less time-adjusted differential costs taken over the Study Period, for an Alternative Building System relative to the base case.

Nonrecurring Costs. Costs that are not uniformly incurred annually over the Study Period.

Non-fuel Operation and Maintenance Costs. Labor and material costs required for routine upkeep, repair, and operation, exclusive of energy costs.

Present Value (Present Worth). The time-equivalent value of past, present, or future cash flows as of the beginning of the Base Year.

Present Value (Present Worth) Factor. A discount factor by which a future dollar amount may be multiplied to find its equivalent Present Value as of the beginning of the Base Year. Single Present Value factors are used to convert single future amounts to Present Values. Uniform Present Value factors are used to convert Annually Recurring amounts to Present Values. 
Replacement Costs. Future costs, included in the capital budget, to replace a Building System or a component during the Study Period.

Retrofit. The installation of an Alternative Building System in an Existing Federal Building.

Salvage Value. The residual value, net of any disposal costs, of any Building System removed or replaced during the Study Period, or remaining at the end of the Study Period, or recovered through resale or reuse at the end of the Study Period.

Savings-to-Investment Ratio (SIR). A ratio computed from a numerator of discounted energy savings, plus (less) savings (increases) in Non-fuel Operation and Maintenance Costs, and a denominator of increased Investment Costs plus (less) increased (decreased) Replacement Costs, net of Salvage Value, for an Alternative Building System as compared with a Base Case.

Sensitivity Analysis. Testing the outcome of an evaluation to changes in the values of one or more system parameters from the initially assumed values.

Simple Payback Period (SPB). A measure of the length of time required for the cumulative savings from a project to recover the Investment Cost and other accrued costs, without taking into account the Time Value of Money or the Differential Energy Price Escalation Rate.

Study Period. The length of the time period covered by the economic evaluation.

Time Value of Money. The time-dependent value of money. If project cash flows are stated in constant dollars, their adjustment to a common time basis is necessary to take into account the real earning potential of investments over time. If project cash flows are stated in current dollars, their adjustment to a common time basis is necessary to take into account not only the real earning potential over time, but also price inflation or depletion. 
Total Life-Cycle Cost (TLCC). The total discounted dollar cost of owning, operating and maintaining a Building or Building System over the Study Period. (See Life-Cycle Costing.)

Useful Life. The period of time over which a Building or Building System continues to generate benefits or savings. 


\section{ACRONYMS}

$\begin{array}{ll}\text { BF } & \text { Ballast Factor } \\ \text { BEF } & \text { Ballast Efficacy Factor } \\ \text { BLCC } & \text { Building Life Cycle Cost } \\ \text { CBM } & \text { Certified Ballast Manufacturer } \\ \text { CFR } & \text { Code of Federal Regulations } \\ \text { CFR } & \text { Cash Flow Report } \\ \text { CMP } & \text { Comparative Economic Analysis } \\ \text { DOE } & \text { Department of Energy } \\ \text { DPB } & \text { Discounted Payback } \\ \text { EPA } & \text { Environmental Protection Agency } \\ \text { ES } & \text { Martin Marietta Energy Systems } \\ \text { ETL } & \text { Engineering Test Laboratory } \\ \text { FBLCC } & \text { Federal Building Life Cycle Cost } \\ \text { FEMP } & \text { Federal Energy Management Programs } \\ \text { KwH } & \text { Kilowatt Hours } \\ \text { LCC } & \text { Life Cycle Costs } \\ \text { NBS } & \text { National Bureau of Standards } \\ \text { NECPA } & \text { National Energy Conservation Policy Act } \\ \text { NEMA } & \text { National Electrical Manufacturers Association } \\ \text { NIST } & \text { National Institute of Standards and Technology } \\ \text { NS } & \text { Net Saving } \\ \text { O\&M } & \text { Operation and Maintenance } \\ \text { OMB } & \text { Office of Management and Budget } \\ \text { OSHA } & \text { Occupational Safety and Health Administration } \\ \text { PB } & \text { Payback } \\ \text { PCBs } & \text { Polychlorinated Biphenyls } \\ & \end{array}$




\section{ACRONYMS}

(Continued)

SIR Savings-to-Investment Ratio

SPB

Simple Payback

TLCC

Total Life-Cycle Cost 


\subsection{STUDY DEFINITION AND REFERENCES}

\subsection{BACKGROUND}

Energy Systems has developed a remediation plan to correct a problem associated with fluorescent light fixture ballasts containing PCBs. In order to comply with the Department of Energy's mandate for Occupational Safety and Health Administration (OSHA) compliance at the $\mathrm{K}-25$ site, the fluorescent ballasts containing PCBs must be removed and properly disposed. Due to the significant cost of implementing the remediation plan and the wide array of replacement ballasts, a Life Cycle Cost Analysis (LCCA) was conducted to choose replacement ballasts while optimizing energy savings and minimizing installation costs.

Technological advances in the design and manufacturing of fluorescent ballasts since the 1978 ban on the use of PCBs in fluorescent ballasts have resulted in ballasts that produce equivalent output lighting levels at reduced input energy requirements. By using the Building Life Cycle Cost (BLCC) computer program provided by National Bureau of Standards to calculate and compare the Life-Cycle Costs (LCC), Net Savings (NS), and Savings-to-Investment Ratios (SIR) for each ballast selected for consideration, the most cost effective replacement ballast system can be identified. This information can be useful in evaluating the economics of implementing the Remediation Plan.

\subsection{APPLICABLE REGULATIONS AND REFERENCES}

The use of PCBs in fluorescent ballasts was banned in 1978 by the Environmental Protection Agency (EPA). The removal of fluorescent ballasts containing PCBs is mandated by 29 CFR 1910, Occupational Safety and Health Standards (OSHA). Replacement ballasts used in retrofit must comply with the following regulations and references: 
- $\quad$ Public Law 100-357.

- Federal Energy Management and Planning Program (FEMP) 10 CFR Part 436, Subpart A.

- $\quad$ Executive Order 12003-1977 amends section 10 of Executive Order 11912.

- $\quad$ Energy Policy and Conservation Act (EPCA) Section 381(a)(2) as amended.

- Title V of National Energy Conservation Policy Act (NECPA), 92 stat., 3275 as amended by Section 405 of the Energy Security Act, 94 stat. 611 .

- Life-Cycle Cost Manual for Federal Energy Management Program, National Bureau of Standards, Handbook 135 (revised 1987).

- Energy Prices and Discount Factors for Life-Cycle Cost Analysis, National Bureau of Standards, NBSIR 85-3273-2.

- $\quad$ A User's Guide to the Federal Building Life-Cycle Cost (FBLCC) Computer Program, National Bureau of Standards, NBS TN 1222.

Remediation Plan for Fluorescent Light Fixtures Containing PCBs, Science Applications International Corporation.

These regulations require the following actions:

- $\quad$ All fluorescent ballasts used after 1978 shall comply with performance standards of Public Law 100-357. 
- An energy reduction of 20 percent on retrofitted Federally leased buildings is required by Executive Order 12003. The Executive Order further directs Federal agencies to consider only those improvements which are energy cost effective based on a life-cycle cost approach. The methodology and procedures for lifecycle cost analysis is established by the Department of Energy (DOE) (in 10 CFR Part 436 Subpart A). Therefore, this life-cycle cost analysis will demonstrate which fluorescent ballasts/fixtures best meet these regulations. 


\subsection{TOTAL LIFE-CYCLE COST ESTIMATING APPROACH}

The Total Life-Cycle Cost approach is used to evaluate the economic performance of capital investment projects, and in this case, the retrofitting or replacing of existing fluorescent lighting ballasts with more energy efficient ballasts and bulbs. This method incorporates initial investment costs; construction costs; replacement costs; operation, maintenance and repair costs; salvage values and disposal costs, including cleanup of leaking ballasts; and other appropriate effects which can be expressed in dollars. The costs and cash flows are adjusted to a consistent time basis and used to calculate a measure of economic performance. Because the method takes into account cash flows over the useful equipment life of the project, not just the initial costs, the method is referred to as a "life-cycle" method.

Expenditures are made throughout the life-cycle study period. In order to have a consistent comparison, all initial investment, replacement and repair costs are stated in constant dollars, that is, dollars of uniform purchasing power tied to the base year and excluding general price inflation or deflation. DOE projected rates of change in energy prices are used for analyzing the life cycle energy cost for each alternative ballast. The DOE discount rate of $4.6 \%$ for 1992 , is used to adjust all dollar values to a Present Value in the year the analysis is made. Therefore, the comparison of alternative units is made in Present Value dollars. This method not only permits the difference in life-cycle costs between two or more alternative systems to be determined, but also permits the effects of investing in more efficient systems in the base year versus spending future dollars to be determined. It is more cost effective to purchase the ballasts at lower base year dollars and reap the lower operating costs during the study period, than to postpone system replacement which results in higher future replacement costs and the loss of energy savings early in the study period. 
Therefore, consistent and rational energy-related investment decisions can be made as mandated by 10 CFR Part 436, Subpart A for Federally owned or leased facilities. The Life-Cycle Cost method is described in greater detail in later sections. 


\subsection{TLCC PROCESS}

\subsection{DEFINITION OF ASSUMPTIONS AND GUIDELINES}

The following is a list of requirements for the LCC Rule for establishing economic data and assumptions: ${ }^{2}$

\subsubsection{Constant Dollars}

All monetary amounts shall be stated in constant dollars in terms of purchasing power of the dollar in the base year. For example, if the LCC evaluation were being made in 1991, a future cost expected to occur in 1994 should be stated as 1991 dollars without an estimate for the purely inflationary/deflationary trends that might cause the general level of prices in the economy to change between 1991 and 1994.

The DOE projected energy prices reflect only the differential price changes and thus are constant dollars.

\subsubsection{Energy}

For this study, the base case energy considered is electrical energy for the fluorescent lighting systems containing ballasts with PCBs. The same systems are studied with each alternative ballast. The amount of energy used varies according to the efficiency of each alternative ballast being studied.

${ }^{2}$ The LCC Rule as set forth in 10 CFR Part 436, Subpart A. 
The energy costs are determined by using actual rate for the base-year and DOE escalation rates for the type of energy and location which in this case is the K-25 Site.

The published discount rate of $4.6 \%$ is used to find present value equivalents of future constant dollar amounts as required by the Energy Security Act for renewable energy projects.

\subsubsection{Investment Costs}

Investment costs are treated as a lump-sum present value amount occurring at the beginning of the base year. This is a simplification which allows costs already in present value dollars to be used without discounting. It avoids the need to adjust for the corresponding delay in cash flows, which occurs with expenditures such as energy costs. Since the main purpose of the study is to find the most cost effective unit rather than to define an exact amount of savings, the simplification does not impact the desired result.

\subsubsection{Annually Recurring Operating and Maintenance Costs}

There are no costs that occur annually in equal and constant amounts.

\subsubsection{Non-Annually Recurring Repair and Replacement Costs}

These costs include labor, material, and disposal charges that occur at specific times in the study period but are not necessarily repetitive each year. These costs are applied as a lump sum at the end of the year in which they are estimated to occur. 


\subsubsection{Study Period}

The Energy Security Act of 1980 limited the study period from 30 years to 25 years because of the great uncertainties of energy prices in the distant future. This study considers all case studies for time periods of $10,15,20$, and 25 years. Once the lowest life-cycle cost system was obtained, that system was also evaluated for time periods of 5 and 7 years since the break even period occurred in that time frame. The wide study period permits management to determine the effect of system replacement at any point within the 5 to 25 year study period.

\subsubsection{Determination of Project Cost Effectiveness}

The TLCC for the baseline case and the alternative ballast case with the lowest TLCC was calculated for each duty cycle and study period. If the alternative ballast case TLCC is lower than the base case and meets the performance requirements, it is held to be cost effective. This guideline of choosing the case with the lowest TLCC complies with the requirement that all Federal buildings be life-cycle cost effective in their design and/or retrofit.

\subsection{DATA CRITERIA AND ANALYSIS}

After reviewing the list of manufacturers who have supplied ballasts for the existing systems and those who are currently manufacturing ballasts, twelve ballasts from four reputable manufacturers were selected for study. All comply with performance values of Public Law 100-357 as tabulated in Table 4 of Appendix A. The data for use in the life-cycle cost analysis was collected from the manufacturer's published information and confirmed by each manufacturer as being correct. The ballast factors (BF), input wattage, ballast efficacy factor (BEF), and projected operating life are tabulated in Table 1 . The percentage of saving as referenced to a standard ballast was calculated for each ballast using the input wattage values. The primary questions to be answered by this analysis are: 
- Should the existing ballasts be replaced with the economy electromagnetic type, the mid-range hybrid or the more expensive electronic models?

- Which is the best ballast of those studied and what is the ranking of TLCC?

- What is the impact of changing total fixtures versus ballasts only?

The data was put in a form compatible with the computerized TLCC program. There are two primary costs variables in the study: (a) material cost of ballasts, and (b) energy cost due to variation of efficiency with each ballast. Both of these factors are influenced by the length of the study period. That is, the economy units with low or mid-range energy savings would be expected to have better performance for short study periods, while the more expensive, but higher efficiency, units would be expected to have better performance for longer study periods.

The investment costs consisting of replacement ballasts/fixtures and bulbs, health and safety labor, installation labor, waste disposal, and program supervision were calculated for each system. The appropriate alternative cases from the "Remediation Plan for Fluorescent Light Fixtures Containing PCBs at K-25 Site" were used as a reference with appropriate substitution of material costs for each ballast system. While the base case system had no initial investment costs, it did require total ballast and bulb replacements within their 12 year expected life span. This is the same as the "Change-out as Ballasts Fail" alternative which is very expensive due to treating each failure as a potential PCB leaking ballast. The replacement costs for the base case were divided into four equal amounts occurring in years $3,6,9$, and 12. These costs were treated as Replacement costs in the calculation formula. 
Another cost in the study for all systems was the routine maintenance expense of replacing fluorescent lamps on a 20,000 hour life cycle. The time sequence for this expense varies with the lighting duty cycle:

\section{Duty Cycle (hrs/yr) \\ 3000 \\ 4000 \\ 6000}

Replacement

Interval (yrs)

$62 / 3$

5

$31 / 3$
Time Cost

Was Applied (yrs)

$7,14,21$

$6,11,16,21$

$3,7,10,13,16,20,23$

Since the program will only take whole numbers, the year of application was rounded to nearest whole number. If a system was receiving new ballasts and bulbs in a re-lamping year, the relamping expense was omitted for those units. These costs occur on an irregular pattern thus they are entered as Non-Annually Recurring Operating and Maintenance expenses in the calculation formula.

In addition to the base case replacement costs of system retrofit, there are replacement costs of the alternative systems which occur during the study period. Of the alternative ballasts considered, all except one have 25 year life expectancy at 50\% duty cycle (approximately 4000 hrs/yr). This ballast has an expected 15 year life. Thus, the life expectancy would be 33 and 20 years respectively for $3000 \mathrm{hrs} /$ year duty cycle. At $6000 \mathrm{hrs} / \mathrm{yr}$ duty, life cycles of 17 and 10 years respectively could be expected. Thus, system change-outs for alternative cases were included as Replacement costs as appropriate.

The second significant factor in the life cycle cost analysis is the energy consumed. As expected the base case has the highest level of energy consumption, with the alternative ballasts providing essentially equivalent lighting output with less energy input. In addition to the lower consumption of electricity by the more efficient ballasts, savings will be realized in lower 
electrical demand charges and electrical line losses. The calculations adjust automatically for lower electrical $\mathrm{Kw}$ demand charges. The energy input data was adjusted manually for line loss savings based on reduced energy demand. Calculations for energy consumed were made using both standard ( 40 watt) lamps and energy savings (34 watts) lamps for each ballast and duty cycle. The electrical rates currently being charged Martin Marietta Energy Systems by Tennessee Valley Authority and the DOE escalation rates for future price adjustments were used to calculate the energy costs. Both the amount of energy used and the electrical rates are listed in Table 2.

The data for each system was entered into the BLCC computer program published by National Bureau of Standards. This information provides a data base from which cash-flow reports, lifecycle costs, and comparative economic analysis can be obtained. The life-cycle costs for all alternative cases were compared to obtain the lowest LCC. It should be noted that only case runs within the same study period and duty cycle can be meaningfully compared. By comparing the lowest LCC of each case study with the lowest LCC of other study period times, the effect of time on LCC performance can be observed. Likewise by plotting the net savings for each of the lowest LCC cases versus study period times, a curve from which the break even point as well as approximate savings at interim study times can be obtained. This type of analysis permits one to evaluate the performance of the best alternate system at any time within the 25 year study period.

In addition to the general data description above, the ballasts/fixtures meet the following specific criteria:

- all monetary amounts are stated in constant dollars,

- all energy comparisons are over same boundaries using DOE projected rates of change in future prices, 
- a discount rate of 4.6 percent is used to discount future amounts to present value,

- $\quad$ study period does not exceed 25 years,

- performance of ballasts meet or exceed performance values of Public Law 100357 , and

a goal of $20 \%$ reduction in energy consumed by lighting systems per 10 CFR Part 436, Subpart $\mathrm{A}$ is met.

\subsection{TLCC MODES OF ANALYSIS}

The TLCC method incorporates initial investment costs, including design, engineering, and construction costs; replacement costs; operation, maintenance and repair costs; salvage values; and disposal costs which can be expressed in dollars. Cash flows are adjusted to a consistent time basis and used to calculate a measure of economic performance. To evaluate the economic performance of energy projects, several economic evaluation methods are available to determine which system is most cost effective.

The modes of analysis considered here are:

(a) Total Life-Cycle Costs (TLCC)

(b) Net Savings

(c) Saving-to-Investment Ratio (SIR)

(d) Simple Payback Period (SPB) 


\subsubsection{Total Life-Cycle Cost (TLCC)}

The total Life-Cycle Cost Analysis uses the following formula:

$$
\mathrm{TLCC}=\mathrm{I}-\mathrm{S}+\mathrm{M}+\mathrm{R}+\mathrm{E}
$$

All amounts are expressed as present value dollars. This formula is used to calculate the baseline case and each alternative case. The system with the lowest TLCC is the most cost effective.

\section{LEGEND FOR TLCC}

TLCC $=\quad$ Total Life-Cycle Cost

$I=\quad$ Investment Costs for this study, the Remediation Plan costs for material, labor, and waste disposal are used.

$S=\quad$ Salvage Value - The removed ballasts and bulbs are considered to have zero salvage value.

$\mathbf{M}=\quad$ Non-fuel Operating and Maintenance Costs $=\mathrm{Ma}+\mathrm{Mb}$

Ma Annually recurring operating and maintenance costs which are incurred each year as an equal, constant dollar amount throughout the study period.

$\mathrm{Mb}$ Non-annually recurring operating and maintenance costs that occur only in specific years.

$\mathrm{R}=\quad$ Replacement Costs. This includes labor and material to replace ballasts and bulbs whose operating life is shorter than study period.

$\mathrm{E}=\quad$ Energy Costs. Electricity consumed during study period consisting of usage rate and demand charge. DOE price escalation rates are used for future energy costs. 


\subsubsection{Net Savings (NS)}

Once the lowest life cycle cost alternative system is found, the net savings between the base case system and the alternative system can be found by using the following formula:

$$
\mathrm{NS}=\mathrm{TLCC}_{\mathrm{BC}}-\mathrm{TLCC}_{\mathrm{A}}
$$

LEGEND FOR NS

NS $=$ Net Savings

$\mathrm{TLCC}_{\mathrm{BC}}=\mathrm{TLCC}$ for the Base Case system

$\mathrm{TLCC}_{\mathrm{A}}=\mathrm{TLCC}$ for the alternate system

This yields the Net Savings in Present Value dollars after all costs are considered for both systems. A positive NS generally means an alternative system that is cost effective for the study period. It is used to determine the degree of effectiveness rather than best of many alternatives.

\subsubsection{Savings-To-Investment Ratio (SIR)}

The SIR is a mode of analysis which expresses savings as a ratio to costs. The numerator is the reduction in energy costs, plus any decrease or (minus any increase) in non-fuel operation maintenance and repair costs. The denominator is the increase in investment cost plus any increase or (minus any decrease) in replacement costs, and minus any increase (or plus any decrease) in salvage values. This method is primarily used to rank different alternatives rather than to select the best of many alternatives. 


\subsubsection{Simple Payback Period (SPB)}

The payback analysis finds how long it takes an alternative system to break even in the sense of recovering investment costs. Another mode of analysis will be used to determine the best alternative and this method will provide supplemental information. In the simplest form (no discounting taken into account) the formula for simple payback (SPB) is:

$$
\mathrm{SPB}=\mathrm{AI}-\mathrm{AS}
$$

where

$\mathrm{AI}=$ Differential Investment Cost

$\mathrm{AS}=$ Future yearly savings net of future yearly costs

An easier method of determining break even is to read the time when the net savings is zero (0) from a net savings versus time plot.

For purposes of this study the TLCC mode will be the primary mode of analysis to determine the most cost effective system. The other modes NS, SIR, and SPB will be used for supporting information.

\subsection{APPLICATIONS}

\subsubsection{Determining Cost Effectiveness}

There are two basic approaches to assessing relative cost effectiveness of alternative concepts. First, the assessment may be made on the basis of relative costs for equally effective systems. The second assessment is to evaluate the relative effectiveness of systems of equal cost. For the 
Life Cycle Cost Analysis of Replacement of Fluorescent Light Fixtures Containing PCBs at K25 , the first approach was selected. In making this selection, it was recognized that the acceptance of candidates with "equal" effectiveness would require that the definition of equal effectiveness be such as to permit a small range of effectiveness variance. In the case of the list of Fluorescent Light Fixture candidates, all candidates listed produced within six percent of rated light level. This means that all units could provide the required lighting levels. Therefore, the system with the lowest TLCC for a period of study is deemed to be most cost effective for that study.

\subsubsection{Time Value of Monies}

The concept of discounting is employed by the BLCC model and also is incorporated into the SAIC version of this model. Discounting or time value of monies is a method of reflecting the possibility that the capital being considered for investment might otherwise be employed so as to generate income at a fixed rate of return. Making this assumption, the relative value of monies at any future time would be less than those same monies at the present time. This is the result of investing these monies and receiving a gain based on the compounded return at a fixed rate of interest. The calculation of the present worth of future monies is calculated according to the formula:

$$
\mathrm{PV}=\mathrm{FV} /(1+\mathrm{i})^{\wedge} \mathrm{n}
$$

where $\mathrm{PV}$ is the present value of monies,

$\mathrm{FV}$ is the future value of monies,

$i$ is the discount rate,

$\mathrm{n}$ is the number of years between the present and the future times.

For a multiple year situation, the discounting routine views the cash flow stream of net result of income and expenses as a series of payments or debts. The Present Value of this cash flow 
stream is calculated by summing each individual time periods PV to FV. If the stream is constant the calculation can be simplified by using the following equation:

$$
\left.\left.\left.\mathrm{PV}=\mathrm{FV} /(1+\mathrm{i})^{\wedge} \mathrm{n}\right)-1\right) / \mathrm{i}\right)
$$

The BLCC computer program gives a method of evaluation which eliminates the need for manual calculations. 


\subsection{DEFINITIONS OF BASELINE AND ALTERNATIVE CASES}

\subsection{BASELINE CASE}

The existing lighting systems at $\mathrm{K}-25$ as described in the "Remediation Plan for Fluorescent Light Fixtures Containing PCBs" are used as the base case for determining the level of energy consumed. These will be compared to alternative replacement systems. The existing lighting systems consist primarily of fixtures with electromagnetic type ballasts and standard bulbs. Some units have been replaced with newer more energy efficient types. The performance level of the older ballasts will be lower because of age and accumulation of dirt on the bulbs so as to offset higher efficiencies of newer ballasts and bulbs. Therefore, the existing systems shall be treated as if all existing ballasts are old electromagnetic ballasts performing at rated values. The baseline case shall be used as the reference level of energy consumption to which alternate cases will be compared.

\section{Baseline Case Data}

Location: 91 Buildings at K-25 Site

Fluorescent Light Fixtures - Approximately $\quad 27,960$

Total Number of Ballasts $\quad 47,036$

Input wattages for fixtures equipped with standard F40T12/RS 40 Watt 4-ft long bulbs are:

One Ballast Two Bulbs (1B2B) 2 - F40T12/RS 120V 96 Watts/Input

Two Ballast Four Bulbs (2B4B) 4 - F40T12/RS 120V 192 Watts/Input 


\section{Fixture Distribution By Type and Location}

Type

Radiation Area

\section{Location $^{3}$}

1 Ballast 2 Bulbs

(1B2B)

2,843

6,041

2 Ballasts 4 Bulbs

(2B4B)

6,104

12,972

Lighting duty cycles to be considered:

3,000 hours/year-approximately 8 hours/day

4,000 hours/year-approximately 12 hours/day

6,000 hours/year-approximately 16 hours/day

Type of Energy: Electricity

Price Per Unit: $\quad \$ 0.03 / \mathrm{KWH}$ (ENERGY ONLY)

Annual Demand Charge: $\$ 9.27 / \mathrm{KW} / \mathrm{MON}$ x $12 \mathrm{MON} / \mathrm{YR}=\$ 111.24 \mathrm{KW} / \mathrm{YR}$

Remaining Building Life: Indefinite

Study Periods: $5,10,15,20,25$ years

The baseline case has no initial investment costs with the ballasts going to failure before being replaced. For studying the 12 alternative ballasts, this method of failure is equal to the Remediation Plan alternative 3 "Change-out Ballasts as They Fail," which has a projected cost

3 The fixtures are classified by the number of ballasts and bulbs in a fixture and whether they are is located in radiation or non-radiation area requiring protective equipment for servicing. 
of $\$ 18,431,450$. Since the old style ballasts have a maximum expected life of 12 years, the cost of replacement was divided into four equal amounts of $\$ 4,608,000$ in years $3,6,9$, and 12 .

For studying the fixtures and bulb change-out, the baseline case is obtained by substituting fixtures containing Magnetek Universal Plus ballasts for ballasts with appropriate adjustments to labor and disposal costs.

The baseline case values for the Life-Cycle Cost formula are as follows.

$\mathrm{TLCC}=\mathrm{I}-\mathrm{S}+\mathrm{M}+\mathrm{R}+\mathrm{E}=$

$I=$ Initial investment costs $(\$ 0)$

$S=$ Removed units must be properly disposed (\$0)

$\mathrm{Ma}+\mathrm{Mb}=$ Annually recurring non-fuel operating and maintenance costs.

$\mathrm{Mb}=$ Non-annually recurring operating and maintenance costs for replacing light bulbs on a life cycle of 20,000 hours. The replacement cycle varies with duty cycle of $3,000,4,000$, or 6,000 hours per year. (See Appendix A for costing of bulb only replacement.)

$\mathbf{R}=$ The replacement costs of labor, material, and waste disposal (Shown here with total cost "Change-out Ballasts as They Fail" of $\$ 18,431,490$ being applied in equal amounts of $\$ 4,608,000$ in years $3,6,9$, and 12 with all units to be changed out in expected life period of 12 years).

$\mathrm{E}=$ Energy consumed by all units for respective duty cycle.

Units x Watts/Unit x Hours/Year - 1000 Watts/KW

3,000 hours/year $\frac{47,036 \times 96^{4} \times 3,000}{1,000}=13,546,368 \mathrm{KWH} /$ year

4,000 hours/year $\frac{47,036 \times 96^{4} \times 4,000}{1,000}=18,061,824 \mathrm{KWH} /$ year 
6,000 hours/year $\frac{47,036 \times 96^{4} \times 6,000}{1,000}=27,092,736 \mathrm{KWH} /$ year

The computer program applies unit electric usage rate, demand charge, and DOE escalation rate to energy consumed to obtain costs.

\subsection{ALTERNATIVE BALLAST CASES}

Alternative cases will consider ballasts and bulbs that have a potential for providing lower lifecycle costs than the baseline case for study periods of $5,10,15,20$, and 25 years. From these case runs the lowest life-cycle cost can be found. The existing lighting systems have ballasts manufactured by several companies. The following list gives original manufacturer and present manufacturers considered in the study:

\section{$\underline{\text { Ballast Manufacturers }}$}

Existing Base

Case Systems

Advance

General Electric

Jefferson Electric

Universal

Westinghouse

\section{Current}

Ballast Manufacturers

Advance

Valmont Electric

Magnetek Inc.

Magnetek Inc.

Not Available

NewCo Inc. (NCI)

\section{$\underline{\text { Remarks }}$}

GE sold to Valmont

Jefferson \& Universal are part of Magnetek Inc.

Westinghouse no longer makes ballast

This gives four reputable manufacturers with ballasts that comply with new performance regulations to represent units available in the industry. Advance, Valmont, and Magnetek each

4 Full ballast wattage for two standard 40 watt bulbs 
manufacture both electromagnetic and electronic ballasts, while NewCo manufacturers only the electronic ballast. The current electromagnetic ballasts capacitors do not contain PCBs as did pre-1978 models and they represent a low cost unit with improved ballast efficacy factors (BEF). The electronic ballasts are usually more expensive than the electromagnetic ballasts but have higher BEFs. Thus, there is the potential for the electronic ballasts to outperform the electromagnetic ballasts when considered for a longer period of time. In addition to the electromagnetic and the electronic, some manufacturers also offer a hybrid which uses both electromagnetic and electronic circuits to start the fluorescent lamps; and once lit, electronically cuts power to lamp cathodes. Therefore, the hybrid ballast provides a moderately priced unit with $\mathrm{BEF}$ values that compare with the electronic models.

The life-cycle cost analysis considers each manufacturer's ballast with two standard 40 watt lamps and with two energy efficient 34 watt lamps. This permits comparison of performance for:

Electromagnetic ballast/standard bulbs

Electromagnetic ballast/energy saving bulbs

Electronic ballast/standard bulbs

Electronic ballast/energy saving bulbs

Hybrid ballast/standard bulb

Hybrid ballast/energy savings bulb. 
Since each manufacturer has one or more models, the following code system is used to identify the case studies:

\section{LEGEND:}
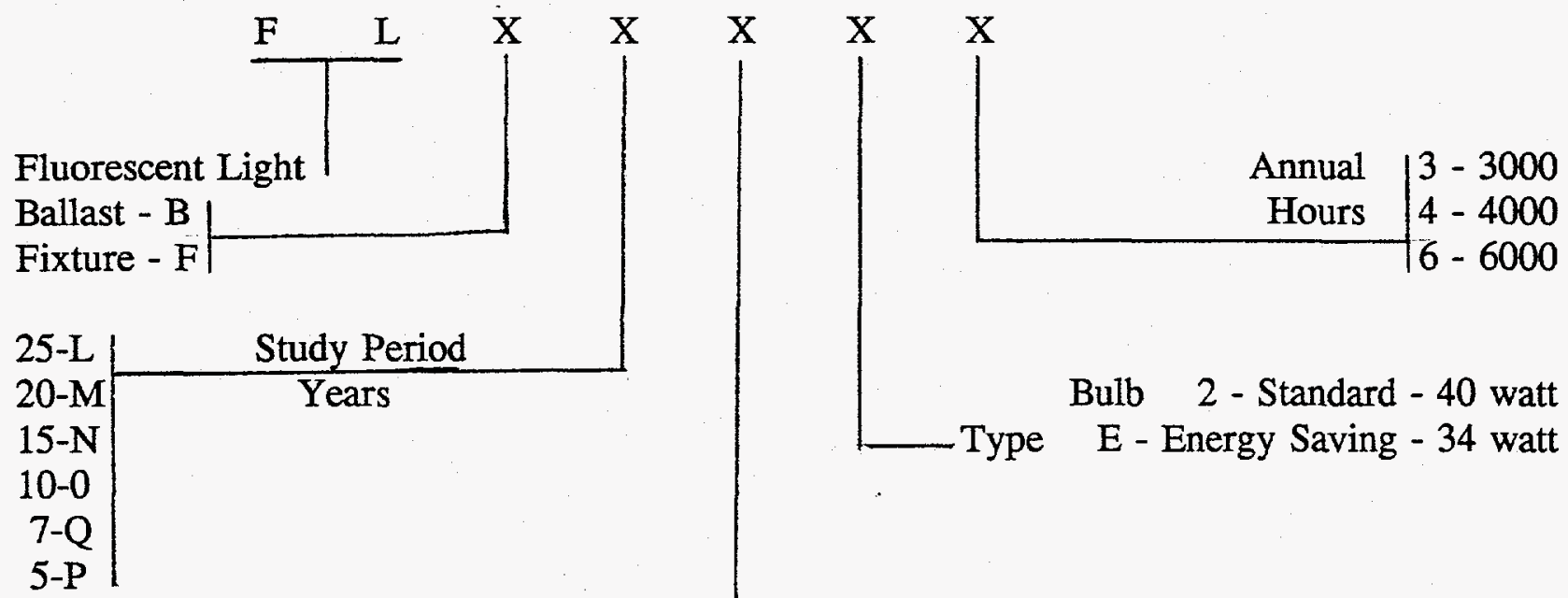

\begin{tabular}{|l}
$\begin{array}{l}\text { Ballast } \\
\text { Identification }\end{array}$ \\
\hline $0-$ Existing Unit
\end{tabular}

Bulb 2 - Standard - 40 watt Type E - Energy Saving - 34 watt

0 - Existing Units (M)*

1 - Advance - Mark III (M)

2 - Advance - Powerkut (M/E)***

3 - Advance - Powerkut Mark IV (M/E)

4 - Advance - Discrete $(\mathrm{E})^{* *}$

5 - NewCo (E)

6 - Magnetek - Watt Reducer (M)

7 - Magnetek - Universal Plus (M/E)

8 - Magnetek - Triad (E)

9 - Valmont - Val Miser (M)

10 - Valmont - Val Maxi Miser (M)

11 - Valmont - Opti Miser (M)

12 - Valmont - Ultra Miser (E)

\footnotetext{
* $\mathrm{M}=$ Electromagnetic

$* * \mathrm{E}=$ Electronic

*** $\mathrm{M} / \mathrm{E}=$ Hybrid
} 
This coding permits the case studies to be identified as file numbers by adding the appropriate file suffixes:

\author{
.DAT - Entry Data \\ .LCC - Life-Cycle Cost Data \\ .DTS - Input Data Report \\ .CFR - Cash Flow Report \\ .LOW - Lowest LCC \\ .CMP - Comparative Economic Analysis
}

\author{
LCCA CASE STUDY MATRIX \\ BALLAST AND BULB Change-out
}

$\begin{array}{llllll}\text { FLBLXS3 } & \text { FLBMXS3 } & \text { FLBNXS3 } & \text { FLBOXS3 } & & \\ \text { FLBLXS4 } & \text { FLBMXS4 } & \text { FLBNXS4 } & \text { FLBOXS4 } & & \\ \text { FLBLXS6 } & \text { FLBMXS6 } & \text { FLBNXS6 } & \text { FLBOXS6 } & & \\ \text { FLBLXE3 } & \text { FLBMXE3 } & \text { FLBNXE3 } & \text { FLBOXE3 } & \text { FLBPXE3 } & \text { FLBQXE3 } \\ \text { FLBLXE4 } & \text { FLBMXE4 } & \text { FLBNXE4 } & \text { FLBOXE4 } & \text { FLBPXE4 } & \text { FLBQXE4 } \\ \text { FLBLXE6 } & \text { FLBMXE6 } & \text { FLBNXE6 } & \text { FLBOXE6 } & \text { FLBPXE6 } & \text { FLBQXE6 }\end{array}$

This matrix covers case study periods of $10,15,20$, and 25 years for ballasts used with standard bulbs and study periods of $5,7,10,15,20$, and 25 years for ballasts used with energy efficient bulbs. Lighting duty cycles of 3,000, 4,000, and 6,000 hours per year are considered for each study period. 


\section{LCCA CASE STUDY MATRIX}

FOR TOTAL FIXTURE AND BULB CHANGE-OUT

\section{FLFLXE4 FLFMXE4 FLFNXE4 FLFOXE4 FLFPXE4 FLFQXE4}

This matrix covers the case study periods of $5,7,10,15,20$, and 25 years at a 4000 -hour duty cycle for fixture and bulb change-out on all lighting systems in the 91 buildings listed.

Files for the above are in directories: IBLCC; and IBLCC \BLCCE or can be run from BLCC menu on the discs provided. The discs contain Federal Building Life Cycle Cost (FBLCC) computer program by the National Bureau of Standards.

Table 1 of Appendix B shows survey data for the ballasts being considered. This data includes ballast type, ballast factor (BF), input watts required for rated output of light, ballast efficacy factor (BEF), compliance with Pubic Law 100-357, sound rating, amount of energy saved with 40 and 34 watt bulbs, respectively, and unit costs. Information from Table 1 was used to develop tabulation of input data listed in Table 2. Both tables are shown in Appendix B. Data from Table 2 was loaded into the NBS computer program (FLBCC) for calculating the LifeCycle Cost (LCC), Cash Flow Report (CFR), Comparative Economic Analysis (CMP), and lowest LCC. The variables for the alternative cases included:

$I=\quad$ Initial Investment costs (The Remediation Plan cost of $\$ 8,547,928$ is used as reference cost). Material costs vary with ballast or fixture considered, while labor and waste disposal costs remain unchanged. Table 3 in Appendix B gives investment costs for each alternative ballast or fixture considered.

$S=$ Scrap requires hazardous waste disposal. (\$0) 
$\mathbf{M}_{\mathbf{a}}=$ There are no annually recurring costs. (\$0)

$\mathbf{M}_{\mathrm{b}}=$ Non-annually recurring operating and maintenance costs for replacing light bulbs on a life cycle of 20,000 hours. The replacement cycle varies with duty cycle of $3,000,4,000$, or 6,000 hours per year. See Appendix A for costing of bulb only replacements.

$\mathbf{R}=$ The replacement costs of labor, material, and waste disposal (shown for ballasts and bulbs that have life expectancies less than the length of the study period). Published life expectancies are for $50 \%$ duty cycles or approximately 4,000 hours per year.

$E=$ Energy consumed varies with input power requirements for each ballast and the duty cycle being studied. See Table 2 for energy requirements for each ballast. The computer program applies the unit electric usage rate, demand charge, and DOE escalation rate to energy consumed to obtain costs.

\subsection{ALTERNATIVE FIXTURE CASE}

Once the best performing ballast was determined, another case study was conducted for a total change-out of the fixtures instead of just replacing the ballasts. The fixtures considered were ones equipped with the Magnetek Universal Plus ballast. The base case was considered as "Change-out Fixtures as They Fail" with all fixtures to be changed out within a 12-year period. Replacement fixtures for the base case were also equipped with Magnetek Universal Plus ballasts. The cost calculations for the fixture change-out base case are shown in Appendix C. 
The alternative defined "Fixture Change-out" was conducted for study periods of 5, 7, 10, 15 , 20 , and 25 years and for the duty cycle of 4000 hours. The investment costs for the alternative fixture change-out are shown in Appendix C. The BLCC computer program was used to calculate the LCC costs and net savings relative to the base case at each of the study periods of $5,7,10,15,20$, and 25 years. The Life Cycle Costs and Net Savings for this case study are shown in Figure 5-1 page 2 of 2 and Figure B-1 of Appendix B. 


\subsection{TLCC ANALYSIS RESULTS}

\subsection{COMPARISON OF ALTERNATIVE SYSTEMS}

The ballast Life Cycle Cost and Net Savings relative to existing lighting systems for the full range of ballast candidates evaluated are shown in Figures B-1 and B-32 through B-49 of Appendix B. The ballast LCC rankings are shown in Figures B-2 through B-31. The Life Cycle Cost and Net Savings for the fixture change-out are shown in Figures B-1 and Figures B-50 through B-61. The fixture LCC rankings are shown in Figures B-56 through B-61. A subset of the lowest life cycle costs for both ballast and fixture cases are shown in Figure 5-1 for the lowest cost candidate for different years of plant operations at the three different duty cycles of annual operations. From Figure 5-1 it can be seen that the fixtures which employ the energy saving fluorescent bulbs are the most cost effective over the full range of years of plant operations and hours of annual operations. Further, the FLBX7EX consistently has the lowest life cycle cost of all alternatives. In those fixtures which use the standard bulbs, the lowest life cycle candidate varies with the years of plant operations and hours of annual operations. The shift from the FLBX7SX to the FLBX5SX as the lowest cost is the result of the latter being a more efficient unit but having a higher investment cost. This high investment cost is offset as the total hours of operation increase. The fixture change-out case depicts the higher investment costs of fixtures over ballasts but does follow some LCC pattern, although greater, as the ballast case FLBX7E4 at a duty cycle of 4000 hours.

In evaluating the types of ballasts available, the electromagnet/electronic hybrid (FLBX76EX) proved to be the most cost effective with the greatest savings realized when energy efficient bulbs are used. The most cost effective ballast is a low cost unit (\$11.28) with a (40\%) energy savings over that of base case units. 


\begin{tabular}{|c|c|c|c|c|c|c|c|}
\hline $\begin{array}{c}\text { Years of } \\
\text { Operations } \\
\end{array}$ & Annual Hours & Alternative & Investment* & $\begin{array}{l}\text { LIFE CYCLE } \\
\text { COST } \\
\text { Standard Bulb } \\
\end{array}$ & Alternative & Investment* & $\begin{array}{c}\text { LIFE CYCLE } \\
\quad \text { COST } \\
\text { Energy } \\
\text { Saving Bulb } \\
\end{array}$ \\
\hline \multirow[t]{3}{*}{5} & 3000 & & & & FLBP7E3 & $\$ 8111$ & $\#_{5792}$ \\
\hline & 4000 & & & & FLBP7E4 & 8111 & 6310 \\
\hline & 6000 & & & & FLBP7E6 & 8111 & 8248 \\
\hline \multirow[t]{3}{*}{7} & 3000 & & & & FLBQ7E3 & 8111 & 9750 \\
\hline & 6000 & & & & FLBQ7E4 & 8111 & 11,362 \\
\hline & & & & & FLBQ7E6 & 8111 & 12,224 \\
\hline \multirow[t]{3}{*}{10} & 3000 & FLB07S3 & 8111 & 11,980 & FLBO7E3 & 8111 & 11,601 \\
\hline & 4000 & FLBO5S4 & 8111 & 12,717 & FLBO7E4 & 8111 & 12,211 \\
\hline & 6000 & FLBO5S6 & 8862 & 15,188 & FLBO7E6 & 8111 & 14,495 \\
\hline \multirow[t]{3}{*}{15} & 3000 & FLBN7S3 & 8111 & 13,973 & FLBN7E3 & 8111 & 13,431 \\
\hline & 4000 & FLBN5S4 & 8862 & 15,051 & FLBN7E4 & 8111 & 14,355 \\
\hline & 6000 & FLN05S6 & 8862 & 18,593 & FLBN7E6 & 8111 & 17,925 \\
\hline \multirow[t]{3}{*}{20} & 3000 & FLBM7S3 & 8111 & 14,998 & FLBM7E3 & 8111 & 14,321 \\
\hline & 4000 & FLBM5S4 & 8862 & 16,798 & FLBM7E4 & 8111 & 16,116 \\
\hline & 6000 & FLBM5S6 & 8862 & 24,194 & FLBM7E6 & 8111 & 23,197 \\
\hline \multirow[t]{3}{*}{25} & 3000 & FLBL5S3 & 8862 & 16,297 & FLBL7E3 & 8111 & 15,606 \\
\hline & 4000 & FL_BL5S4 & 8862 & 18,212 & FLBL7EA & 8111 & 17,529 \\
\hline & 6000 & FLBL5S6 & 8862 & 26,445 & FLBL7E6 & 8111 & 25,465 \\
\hline
\end{tabular}

All Costs (Thousands)

VARIATION OF LIFE CYCLE COST FOR LOWEST CANDIDATE (BALLAST CHANGE-OUT) FOR STUDY PERIOD OF Y-25 YEARS AND DUTY CYCLES OF 3000, 4000, AND 6000 HOURS 


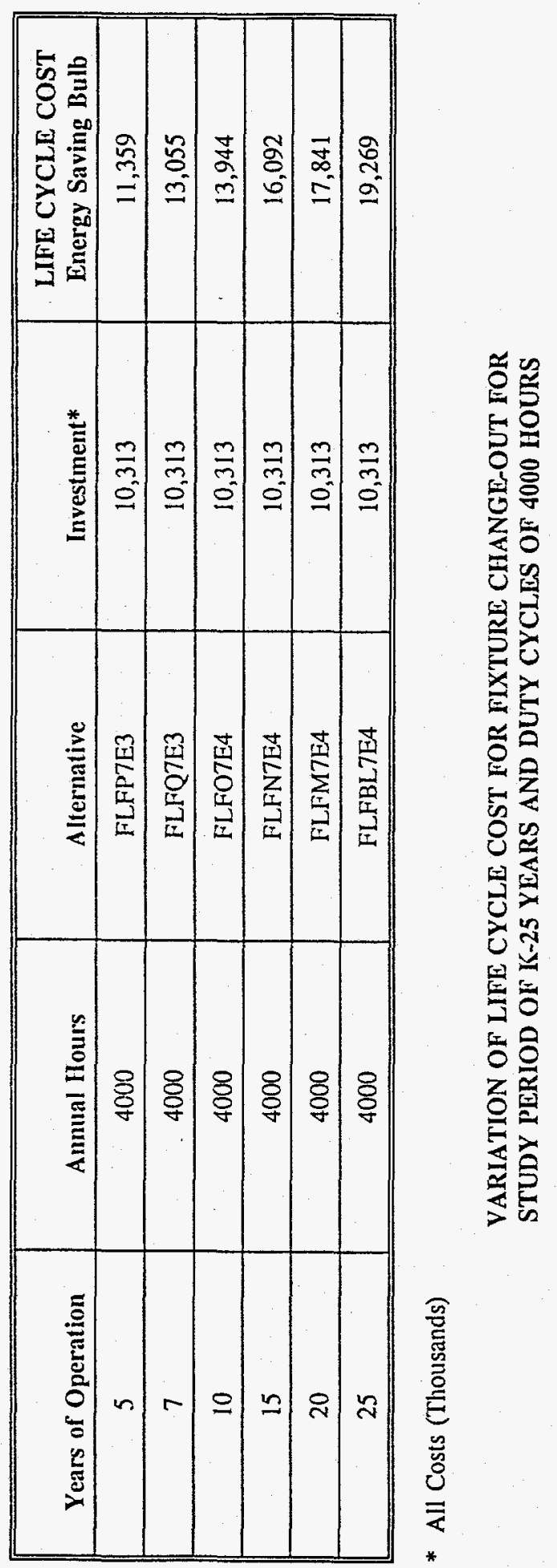

FIGURE 5-1

Page 2 of 2 
The number two unit was electronic model FLBX5EX which was higher in cost $(\$ 28.00)$ with a (44\%) energy savings over base case units. This unit becomes more cost effective with longer study periods with the initial investment costs being overcome by greater energy savings.

Other sensitivities were investigated using the SAIC model. In general, the variations in labor and material costs were reflected directly into the investment cost and subsequently reduced the life cycle saving. These impacts are linear and effect only the annual savings and the total savings. The payback period shifts to the right or left as the cumulative effects of the variances add or subtract to the nominal investment costs. These variations do not change the relative ranking of the alternative life cycle costs.

\subsection{CHOOSING AMONG ALTERNATIVES}

The choice of which alternative represented the best solution to the requirement for Fluorescent ballast or fixture replacement can be made based on any of the four modes of analysis discussed in Section 3.3. The choice will differ depending upon the expected operational life expectancy and annual hours of operation of the K-25 complex, and upon specific goals such as a desire to achieve maximum energy efficiency, minimum initial investment and/or quickest investment recover. For the purposes of this study, the total life cycle cost was chosen as the best indicator for candidate selection. The total life cycle in this case can be defined as operations over any number of years up to the maximum of 25 years. By looking at a life cycle cost for various operational lifetimes $5,10,15$, and 25 years, the sensitivity of plant operational life can be addressed. Similarly, by assessing the point of breakeven or payback within the context of life cycle costs, the time sensitivity of payback to plant operational life can be assessed using the life cycle cost technique. Net Savings and Savings-to-Investment Ratios can be used to augment the life cycle cost assessment as required. These latter two criteria are more important if there is less sensitivity to initial investment costs. Greater relative savings may result from higher initial 
investments over a full 25 year operating life but these higher initial investments are very sensitive to variances in plant operating life.

The Department of Commerce, National Bureau of Standards Building Life Cycle Cost (BLCC) computer program was used along with a Science Application International Corporation (SAIC) version of this model to conduct the life cycle cost comparison. To provide sensitivity assessments along with the evaluation of the absolute life cycle cost assessment, it was decided that the costs of the various alternatives would be calculated and viewed in parametric form. This approach allowed the integrated assessment of the effects of plant operational life, initial investment, fixture efficiency and time value of monies. The BLCC model was run for all of the ballast candidates for operational lifetimes of 5, 10,15, 20 and 25 years and for annual hours of operations at 3000,4000 and 6000 hours. The initial selection of the best ballast alternatives was made based on the lowest life cycle costs for 25 years with an annual operational level of 4000 hours. This candidate was then subjected to additional assessments. Figure 5-2 shows the Life-Cycle Costs for years 10 through 20 years with standard bulbs for each of duty cycles $3,000,4,000$, and 6,000 hours per year. The same ballast candidate with energy efficient bulbs and duty cycles of 3000,4000 , and 6000 hours per year was analyzed for years 5 through 25 years also. The fixture case LCC cost data is also shown in Figure 5-2 for study periods of 5, $7,10,15,20$, and 25 years. Figure $5-3$ shows the net savings of the ballast candidate and the fixture case at study times from 5 to 25 years. The break even point is in the seven to eight year range for the ballast candidate using energy efficient bulbs with the higher duty cycle resulting in the earliest break even point. The breakeven point for the fixture case is approximately 10 years. Thus, the ballast change-out is a more cost-efficient installation than changing out all the fixtures. This is due to the fixtures having higher material and labor costs. In particular these candidates were analyzed for their relative payback periods and for sensitivity points in terms of annual hours of operations and years of plant operations. All of the selected candidates exhibited a sensitivity to annual hours of operations in excess of 4000 hours. At 6000 hours annual hours of operations, a replacement in ballasts was required at approximately the seventeenth year. The life cycle costs reflect a significant reduction in the overall life cycle cost savings after the point of reinvestment. 


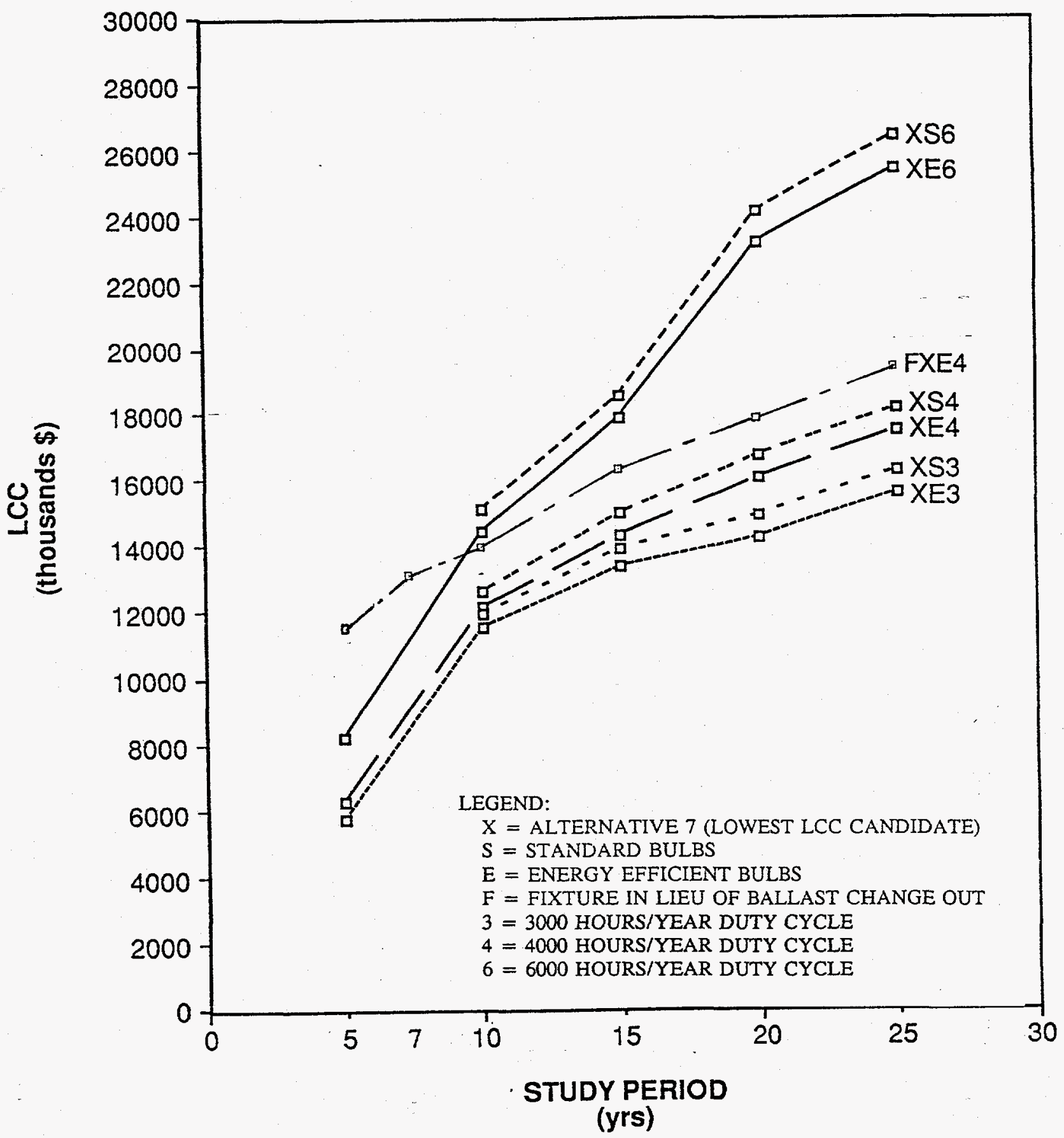

FIGURE 5-2. LOWEST LIFE CYCLE COST VERSUS STUDY PERIOD 


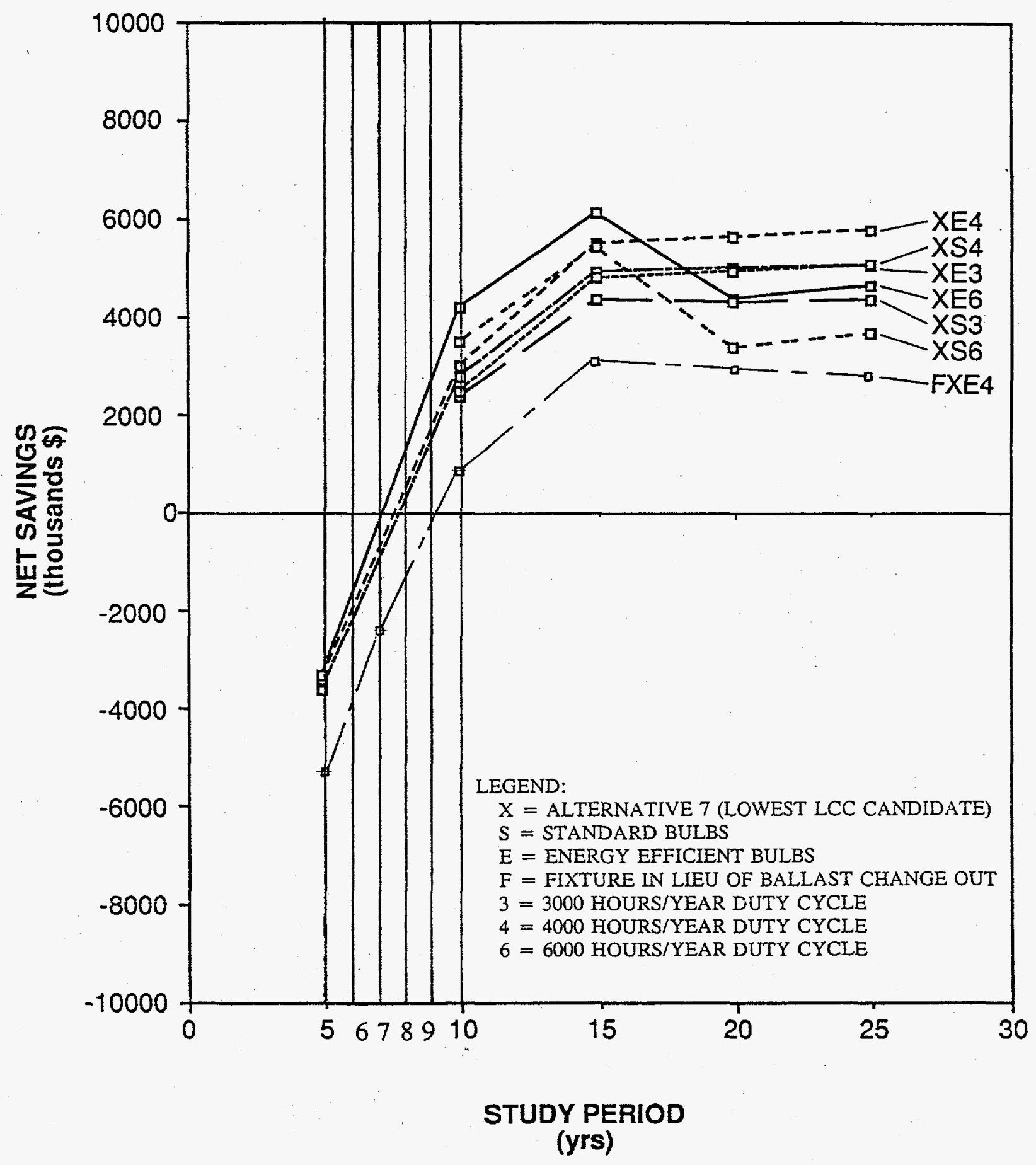

FIGURE 5-3. NET SAVINGS VERSUS STUDY PERIOD 
Figure 5-4 is the Energy Conservation Survey Summary. Data from the computer program for Total Equipment Cost (TEC), Savings to Investment Ratio (SIR), Simple Payback (SPB), Average Annual Energy Saved, Total Study Period Savings and Average Annual Savings are tabulated for easy comparison. This compilation indicates the favorable energy savings that results from changing out the ballasts and/or fixtures containing PCBs in addition to solving the PCB environmental issue.

\subsection{RECOMMENDATIONS}

Based on the use of the lowest life cycle cost criteria, the recommended ballast candidate is the Magnetek Universal Plus (FLBX7EX) with the energy saving bulbs. This candidate will accomplish a payback of the investment in approximately 7 to 8 years. Even with extreme, adverse variations in labor and materials, this candidate would accomplish payback in less than 10 years. Increased hours of operations reduces the time to achieve payback. Therefore with reasonable risk, the recommended candidate would hold with a reasonable likelihood that the plant will operate 7 to 10 years after the refurbishment.

The recommendations may be summarized as follows:

1. Use only energy efficient bulbs.

2. Use of low cost ballasts with high energy saving performance (such as electromagnetic/electronic hybrid) will yield most cost effective installation.

3. Electronic ballasts are a close second choice for life cycles of 15 to 25 years. More competitive pricing of electronic ballasts would make them the most cost effective choice.

4. Total fixture change is a cost-effective solution that ranks as third choice as the result of higher investment costs. 
1. Survey Location - K-25 Site

3. Survey Start - 1991

5. Building or Systems Surveyed (Brief Discussion)
2. Fiscal Year Funding - TBD

4. Survey Complete - March 13, 1992

A. Performed life cycle cost analysis for possible replacement of fuorescent light fixtures containing PCBs with new energy efficient fixtures and bulbs. Approximately 28,000 fixtures located in 91 buildings.

\begin{tabular}{|c|c|c|c|c|c|c|c|}
\hline ECO Title \& Case Study & TEC $(\$ \mathrm{~K})$ & $\operatorname{SIR}^{\prime}$ & $\begin{array}{l}\text { Simple }^{2} \\
\text { Payback } \\
\text { (Years) }\end{array}$ & $\begin{array}{c}\text { Avg }^{3} \text { Annual } \\
\text { Energy Saved } \\
(\$ \mathrm{~K})\end{array}$ & $\begin{array}{c}\text { Total }^{3} \text { Study } \\
\text { Period Savings } \\
(\$ K)\end{array}$ & $\begin{array}{l}\text { Avg Annual } \\
\text { Dollars Saved } \\
(\$ \mathrm{~K})\end{array}$ & $\begin{array}{c}\text { Scheduled } 44 \\
(\mathrm{Y} / \mathrm{N})\end{array}$ \\
\hline \multicolumn{8}{|c|}{ Fluorescent Fixtures Replacement } \\
\hline $\begin{array}{l}\text { 1. Case Study: FLFP7E4 } \\
5 \mathrm{yrs}-4000 \mathrm{hrs} / \mathrm{yr}\end{array}$ & 10,313 & 0.12 & 00 & 13.9 & -5401 & -1080 & $\mathbf{N}$ \\
\hline $\begin{array}{l}\text { 2. Case Study: FLFQ7E4 } \\
7 \mathrm{yrs}-4000 \mathrm{hrs} / \mathrm{yr}\end{array}$ & 10,313 & 0.21 & 00 & 140.1 & -2275 & -325 & $N$ \\
\hline $\begin{array}{l}\text { 3. Case Study: FLFO7E4 } \\
10 \mathrm{yrs}-4000 \mathrm{hrs} / \mathrm{yrs}\end{array}$ & 10,313 & 16.52 & 9.3 & 117.9 & 763 & 76.3 & $\mathrm{~N}$ \\
\hline $\begin{array}{l}\text { 4. Case Study: FLFN7E4 } \\
15 \text { yrs - } 4000 \mathrm{hrs} / \mathrm{yrs}\end{array}$ & 10,313 & -0.22 & 9.3 & 79.6 & 2966 & 197.7 & N \\
\hline $\begin{array}{l}\text { 5. Case Study: FLFM7E4 } \\
20 \text { yrs }-4000 \mathrm{hrs} / \mathrm{yrs}\end{array}$ & 10,313 & -0.17 & 9.3 & 55.6 & 2849 & 142.4 & $\mathrm{~N}$ \\
\hline $\begin{array}{l}\text { 6. Case Study: FLFC7E4 } \\
25 \mathrm{yrs}-4000 \mathrm{hrs} / \mathrm{yr}\end{array}$ & 10,313 & -0.14 & 9.3 & 41.2 & 2768 & 110.72 & $\mathrm{~N}$ \\
\hline
\end{tabular}

1. Savings to investment ratio are not meaningful in this study since the capital investment costs for not replacing fluorescent fixtures in planned manner exceeds capital investment costs for energy efficient fixture replacement.

2. Savings from energy and O\&M costs vary irregularly during study periods. Thus, there are no accurate annual savings with which to calculate simple payback. The payback period was obtained graphically in Figure 5-3 at the point net savings is zero.

3. Data are from NIST BLCC Computer Program comparative economic analysis sheets as shown in Appendix B.

Data for fixture and bulb change-out are from Figures B-50 through B-55.

Data for ballast and bulb change-out are from Figures B-32 through B-49. 
B. Performed Life Cycle Cost Analysis for possible replacement of existing fluorescent ballasts containing PCBs with new energy efficient ballasts and bulbs. There are approximately 47,036 ballasts in 28,000 fixtures located in 91 buildings.

\begin{tabular}{|c|c|c|c|c|c|c|c|}
\hline ECO Title \& Case Study & TEC $(\$ K)$ & $\mathrm{SIR}^{\prime}$ & $\begin{array}{c}\text { Simple } \\
\text { Payback } \\
\text { (Years) } \\
\end{array}$ & $\begin{array}{c}\text { Avg }^{3} \text { Annual } \\
\text { Energy Saved } \\
(\$ \mathrm{~K})\end{array}$ & $\begin{array}{c}\text { Total }^{3} \text { Study } \\
\text { Period Savings } \\
(\$ \mathrm{~K}) \\
\end{array}$ & $\begin{array}{c}\text { Avg Annual } \\
\text { Dollars Saved } \\
(\$ K)\end{array}$ & $\begin{array}{c}\text { Scheduled } 44 \\
(\mathrm{Y} / \mathrm{N})\end{array}$ \\
\hline \multicolumn{8}{|c|}{ Fluorescent Ballasts and Bulb Replacement } \\
\hline $\begin{array}{l}\text { 1. Case Study: FLBP7E3 } \\
5 \mathrm{yrs}-3000 \mathrm{hrs} / \mathrm{yr}\end{array}$ & 8548 & 0.15 & 00 & 125.3 & -3635 & -727 & $\mathrm{~N}$ \\
\hline $\begin{array}{l}\text { 2. Case Study: FLBQ7E3 } \\
7 \mathrm{yrs}-3000 \mathrm{hrs} / \mathrm{yr}\end{array}$ & 8548 & 0.86 & $\infty$ & 110.3 & -126 & -18 & $N$ \\
\hline $\begin{array}{l}\text { 3. Case Study: FLBO7E3 } \\
10 \mathrm{yrs}-3000 \mathrm{hrs} / \mathrm{yr}\end{array}$ & 8548 & -0.35 & 7.75 & 199.5 & 2748 & 275 & $\mathrm{~N}$ \\
\hline $\begin{array}{l}\text { 4. Case Study: FLBN7E3 } \\
15 \mathrm{yrs}-3000 \mathrm{hrs} / \mathrm{yr}\end{array}$ & 8548 & -0.06 & 7.75 & 75.5 & 4894 & 326 & $\mathbf{N}$ \\
\hline $\begin{array}{l}\text { 5. Case Study: FLBM7E3 } \\
20 \mathrm{yrs}-3000 \mathrm{hrs} / \mathrm{yr}\end{array}$ & 8548 & -0.08 & 7.75 & 61.8 & 4996 & 250 & $N$ \\
\hline $\begin{array}{l}\text { 6. Case Study: FLBL7E3 } \\
25 \mathrm{yrs}-3000 \mathrm{hrs} / \mathrm{yr}\end{array}$ & 8548 & -0.10 & 7.75 & 52.7 & 5054 & 202 & $\mathrm{~N}$ \\
\hline $\begin{array}{l}\text { 7. Case Study: FLBP7E4 } \\
5 \mathrm{yrs}-4000 \mathrm{hrs} / \mathrm{yr}\end{array}$ & 8548 & 0.20 & 00 & 167.4 & -3425 & -685 & $\mathrm{~N}$ \\
\hline $\begin{array}{l}\text { 8. Case Study: FLBQ7E4 } \\
7 \mathrm{yrs}-4000 \mathrm{hrs} / \mathrm{yr}\end{array}$ & 8548 & 0.86 & $\infty$ & 163 & -124 & -18 & $\mathrm{~N}$ \\
\hline $\begin{array}{l}\text { 9. Case Study: FLBO7E4 } \\
10 \mathrm{yrs}-4000 \mathrm{hrs} / \mathrm{yr}\end{array}$ & 8548 & -0.46 & 7.5 & 131.4 & 2987 & 230 & $\mathrm{~N}$ \\
\hline $\begin{array}{l}\text { 10. Case Study: FLBN7E4 } \\
15 \mathrm{yrs}-4000 \mathrm{hrs} / \mathrm{yr}\end{array}$ & 8548 & -0.19 & 7.5 & 103.5 & 5502 & 367 & $\mathbf{N}$ \\
\hline $\begin{array}{l}\text { 11. Case Study: FLBM7E4 } \\
20 \mathrm{yrs}-4000 \mathrm{hrs} / \mathrm{yr}\end{array}$ & 8548 & -0.22 & 7.5 & 85.6 & 5628 & 281 & $\mathbf{N}$ \\
\hline $\begin{array}{l}\text { 12. Case Study: FLBL7E4 } \\
25 \mathrm{yrs}-4000 \mathrm{hrs} / \mathrm{yr}\end{array}$ & 8548 & 1.71 & 7.5 & 73.7 & 5758 & 230 & $N$ \\
\hline
\end{tabular}




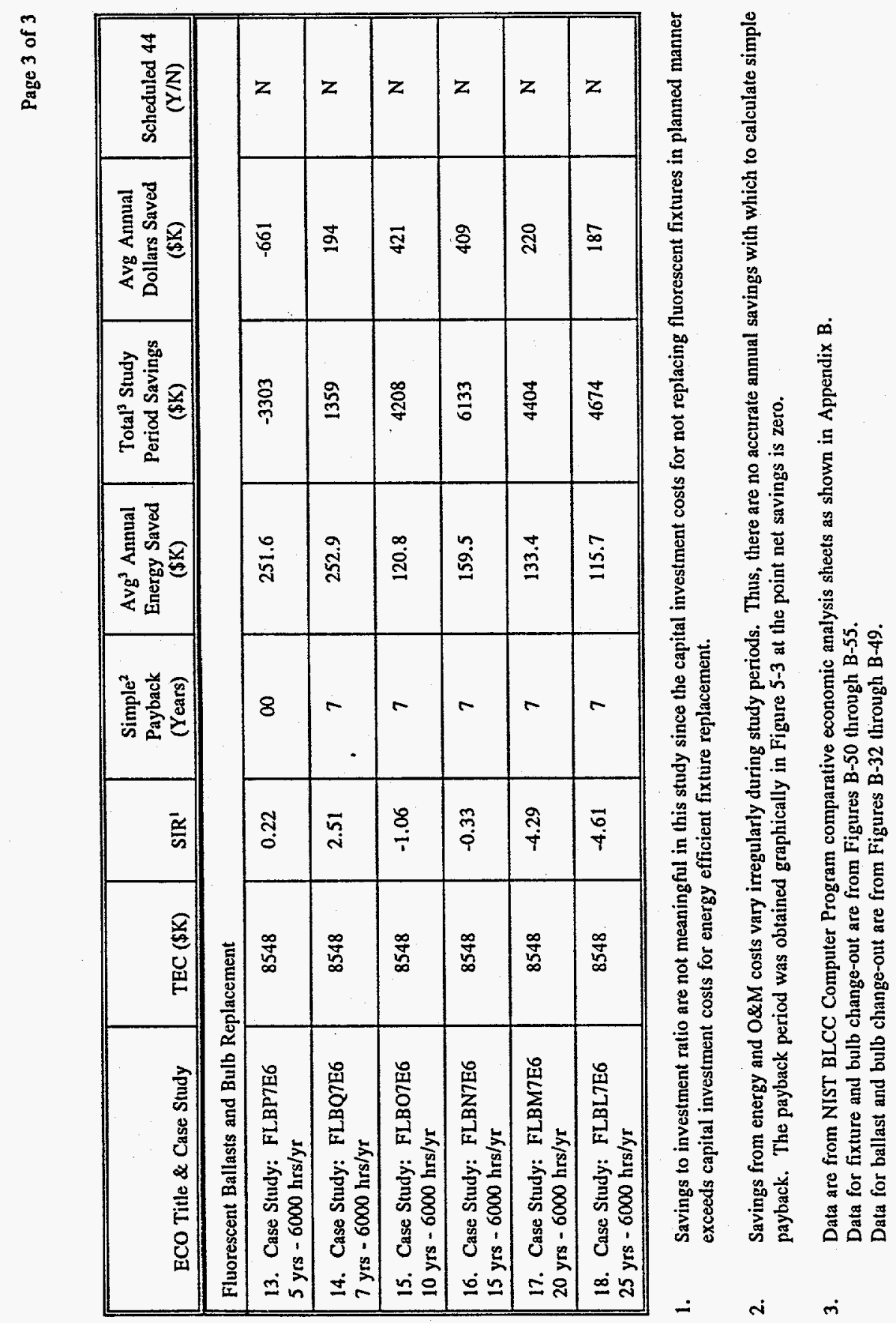




\section{APPENDIX A \\ COSTING OF BULB ONLY CHANGE-OUT}

In changing out fluorescent bulbs on a routine basis, the costs incurred are materials for bulbs (energy efficient), Electrical Maintenance Division personnel, Health Physics personnel in radiation areas, protective equipment for radiation areas and limited supervision. The fixture distribution by type and quantity are:

TYPE

Fixture with 1 Ballast

2 Bulbs (1B2B)

Fixture with 2 Ballasts

4 Bulbs (2B4B)

Total Fixtures

COST ESTIMATE FOR:

Radiation Area

$$
\begin{aligned}
& \text { Material - } 2 \text { bulbs } \\
& \text { Prof. Equip (2) }
\end{aligned}
$$

LOCATION

RADIATION AREA

$$
2,843
$$

6,104

27,960
NON-RADIATION AREA

$$
6,041
$$

12,972
1B2B

$\$ 3.84$

30.00

Labor 1 EMD (0.25mhrs) $\quad 15.00$

$1 \mathrm{HPD}(0.25 \mathrm{mhrs}) \quad \underline{16.00}$

$$
\$ 64.84 \simeq \$ 65.00
$$

2B4B
Material - 4 bulbs

Prof. Equip (2)

Labor 1 EMD $(0.5 \mathrm{mhrs})$

$1 \mathrm{HPD}$ (0.5mhrs)
$\$ 7.68$

30.00

30.00

$\underline{32.00}$

$$
\$ 99.68 \simeq \$ 100.00
$$


Non-Radiation Area

$\begin{array}{lll}\text { 1B2B } & \text { Material }-2 \text { bulbs } & \$ 3.84 \\ & \text { Labor } 1 \mathrm{EMD}(0.25 \mathrm{mhrs}) & \underline{15.00} \\ & & \$ 18.84 \simeq \$ 19.00 \\ \text { 2B4B } & \begin{array}{l}\text { Material }-4 \text { bulbs } \\ \text { Labor } 1 \text { EMD }(0.5 \mathrm{mhrs})\end{array} & \underline{\$ 0.00} \\ & & \$ 37.68 \simeq \$ 38.00\end{array}$

\section{SUMMARY}

Radiation Area:

1B2B 2,843 Fixtures $x \$ 65.00 /$ Fixture $=\$ 184,795$

2B4B 6,104 Fixtures $x \$ 100.00 /$ Fixture $=610,400$

Non-Radiation Area:

1B2B 6,041 Fixtures $x \$ 19.00 /$ Fixture $=\$ 114,779$

2B4B 12,972 Fixtures $\mathrm{x} \$ 38.00$ /Fixture $=492,936$

General Supervisor 2 hours/day x 5 days/wk

$$
\text { x } 50 \text { wks }
$$

500 hours @ \$67.22 \$ $\$ 33.614$

Estimated Total Cost

To Change-out Bulbs Only \$1,436,524 
Values for $\left(\mathrm{M}_{(\mathfrak{b})}\right)$ shown in Table 2 are the summation of the lamping cycles of:

7 year intervals for 3,000 hour duty cycles

5 year intervals for 4,000 hour duty cycles

3 to 4 year intervals for 6,000 hours duty cycles

and the prorated value from bulbs that were included with ballast change-out requirements.

Full System Change-out

1/4 System Change-out

$1 / 2$ System Change-out

$2 / 5(359,000)$ Partial of Base Change

$1 / 5(359,000)$ Partial of Base Change
$\$ 1,437,000$

359,000

719,000

144,000

72,00 


\section{APPENDIX B}

ALTERNATIVE COST DATA 
TABLE 1. BALLAST SURVEY DATA

\begin{tabular}{|c|c|c|c|c|c|c|c|c|c|c|c|c|c|}
\hline 8 & $\dot{\dot{x}}$ & 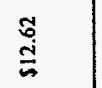 & $\underset{f}{f}$ & 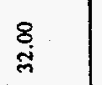 & $\underset{8}{8}$ & $\begin{array}{l}8 \\
\text { i } \\
\text { in }\end{array}$ & ติ & $\stackrel{\text { I̊ }}{=}$ & $\stackrel{8}{8}$ & $\stackrel{\mathbb{0}}{\underline{\Xi}}$ & $\stackrel{9}{\dot{m}}$ & $\stackrel{\text { a }}{ \pm}$ & 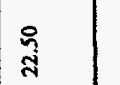 \\
\hline 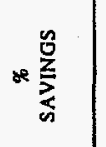 & $\stackrel{\circ}{\xi}$ & $=\approx$ & $\begin{array}{ll}\stackrel{2}{0} & \\
\frac{5}{5} & 8 \\
& \\
\wedge & \end{array}$ & $=\vec{m}$ & $\begin{array}{ll}0 & 0\end{array} \mid$ & $F \quad 7$ & $\therefore=$ & $\begin{array}{ll}2 & 8\end{array}$ & 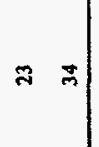 & $\stackrel{ \pm}{\Xi} \mathrm{N}$ & $\approx \pi$ & $\therefore$ & $\because=$ \\
\hline 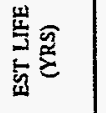 & $\simeq$ & $\bar{A}$ & 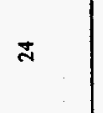 & $\approx$ & 品 & 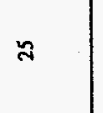 & $\cong$ & $\approx$ & 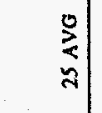 & $\approx$ & $\approx$ & $\stackrel{\check{\nu}}{\grave{z}}$ & 亲 \\
\hline 号是 & & $<<$ & & $\ll$ & 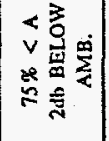 & $<$ & $<$ & $<$ & $<$ & $<$ & $<$ & $<$ & $<$ \\
\hline (6) & $z \quad z$ & $>$ & $=$ & $>$ & $>$ & $>$ & $>$ & $>$ & $>$ & $>>$ & $\Rightarrow>$ & $>x$ & $x>E_{E}^{c}$ \\
\hline 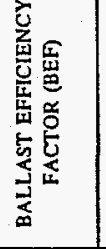 & $\begin{array}{cc}a & 0 \\
-1\end{array}$ & 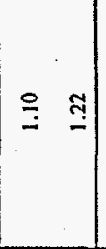 & $\stackrel{\infty}{=} \stackrel{0}{=}$ & $\stackrel{0}{=}$ & $\stackrel{\vartheta}{\beth}$ & 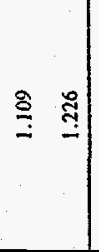 & 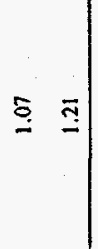 & $\cong \stackrel{\infty}{=}$ & $\stackrel{\infty}{=}$ & $\stackrel{9}{9}$ & $\stackrel{\circ}{\Xi}$ & 急 & $\stackrel{\text { I্ }}{-} \stackrel{9}{-}$ \\
\hline 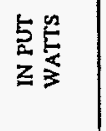 & : $\tilde{\infty}$ & $\infty \approx$ & $=\infty$ & $\triangle 8$ & $=i$ & $n=\dot{n}$ & $\begin{array}{ll}\infty & \bar{\infty}\end{array}$ & $=\infty$ & $=5$ & $\begin{array}{lll}\infty & \&\end{array}$ & $\stackrel{2}{2}$ & $=\infty$ & 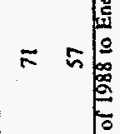 \\
\hline 点 & $\therefore \quad \infty$ & $\approx \infty_{\varphi}^{\infty}$ & $\begin{array}{ll}\vec{a} & \overline{9}\end{array}$ & 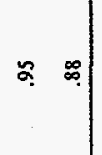 & \begin{tabular}{cc}
$\infty$ & $\infty$ \\
\hdashline & $\infty$
\end{tabular} & 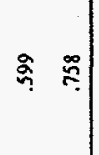 & 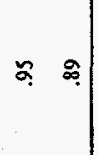 & $\begin{array}{ll}\infty & 0 \\
0 & 0\end{array}$ & $\begin{array}{ll}\overline{1} & \bar{\infty}\end{array}$ & 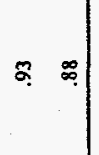 & $\stackrel{0}{0}$ & $\approx \quad \bar{\square}$ & œ \\
\hline 蒙 & 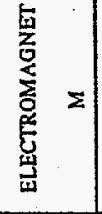 & $z=$ & $\frac{\omega}{\Sigma} \frac{\mu}{\Sigma}$ & $\frac{\omega}{2} \frac{\omega}{2}$ & 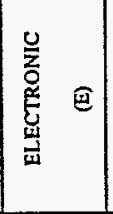 & $\Leftrightarrow$ & $\Sigma \Sigma$ & $\frac{\mu}{\Sigma} \frac{\omega}{\Sigma}$ & $\omega$ & $\Sigma \Sigma$ & $\Sigma \Sigma$ & $\frac{\omega}{\Sigma} \frac{\omega}{\Sigma}$ & wa \\
\hline 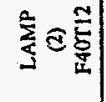 & $\mid \begin{array}{ll}\mathrm{R} & \dot{\mathrm{s}} \\
\mathrm{i}\end{array}$ & 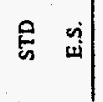 & 量 & 它 & $\Leftrightarrow \begin{array}{cc}0 \\
\dot{n}\end{array}$ & 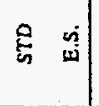 & $\begin{array}{cc}\dot{E} & \dot{v} \\
\dot{H}\end{array}$ & 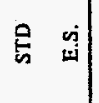 & 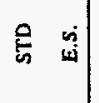 & $\begin{array}{cc}\hat{\xi} & \dot{0} \\
\dot{\omega}\end{array}$ & 点 & 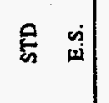 & 量 \\
\hline 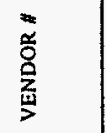 & 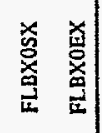 & 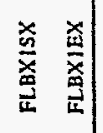 & 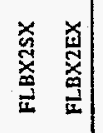 & 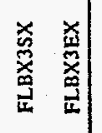 & 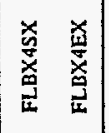 & 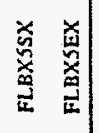 & 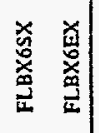 & 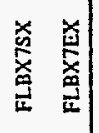 & 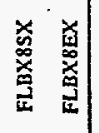 & 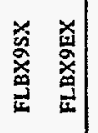 & 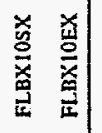 & 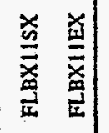 & 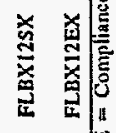 \\
\hline
\end{tabular}

April 29, 1992

Page B-1 


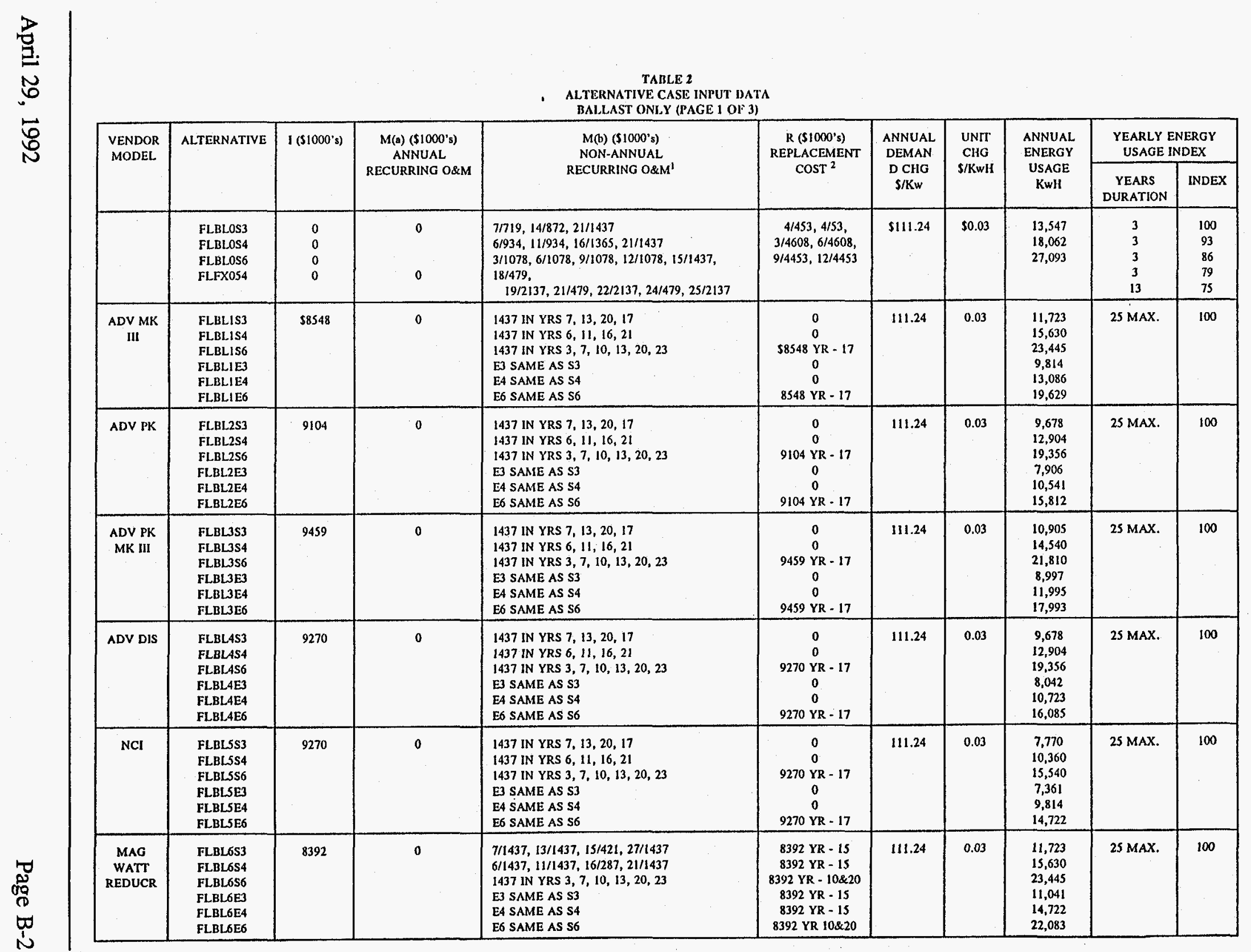




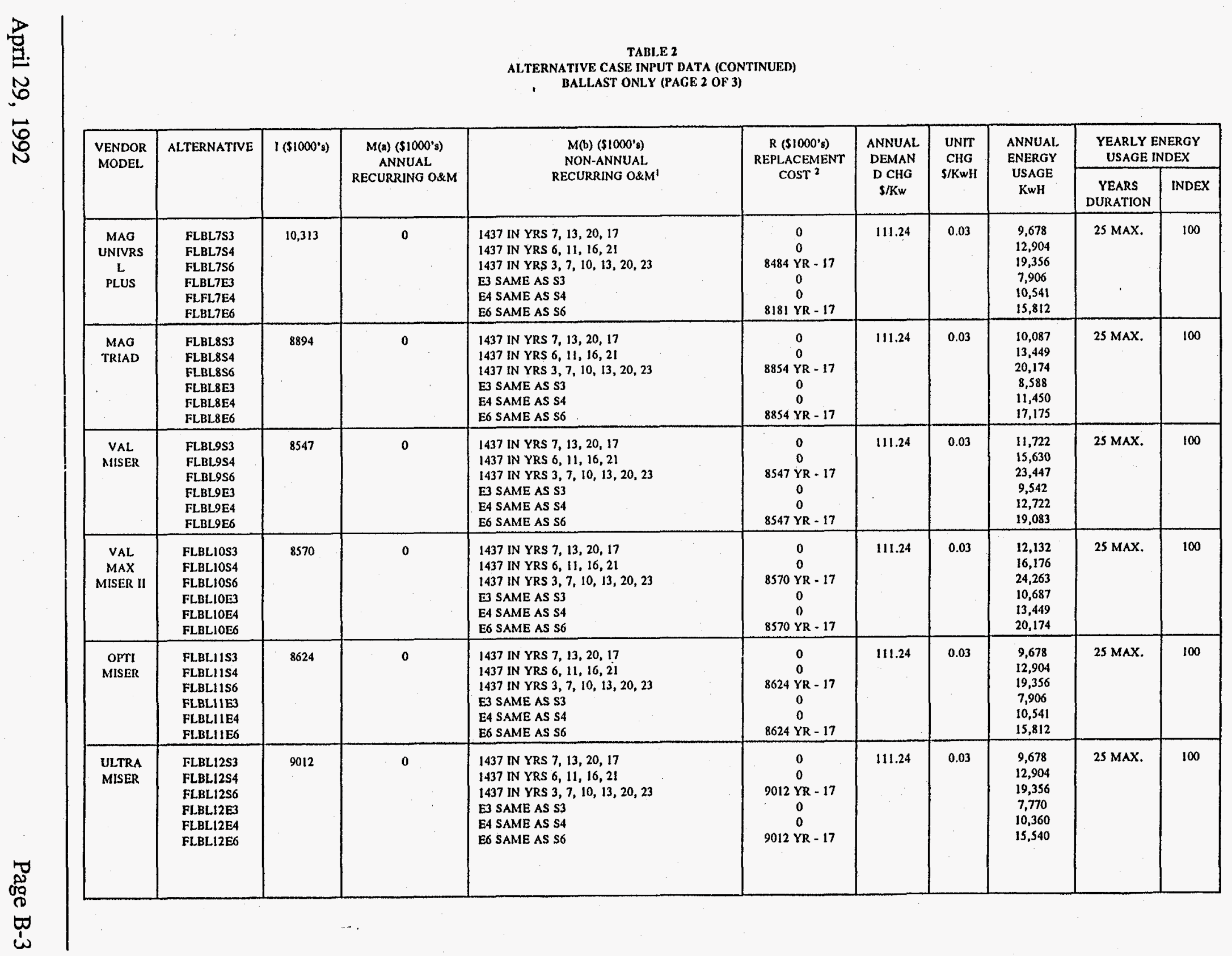


TABLE 2. ALTERNATIVE CASE INPUT DATA (CONTINUED)

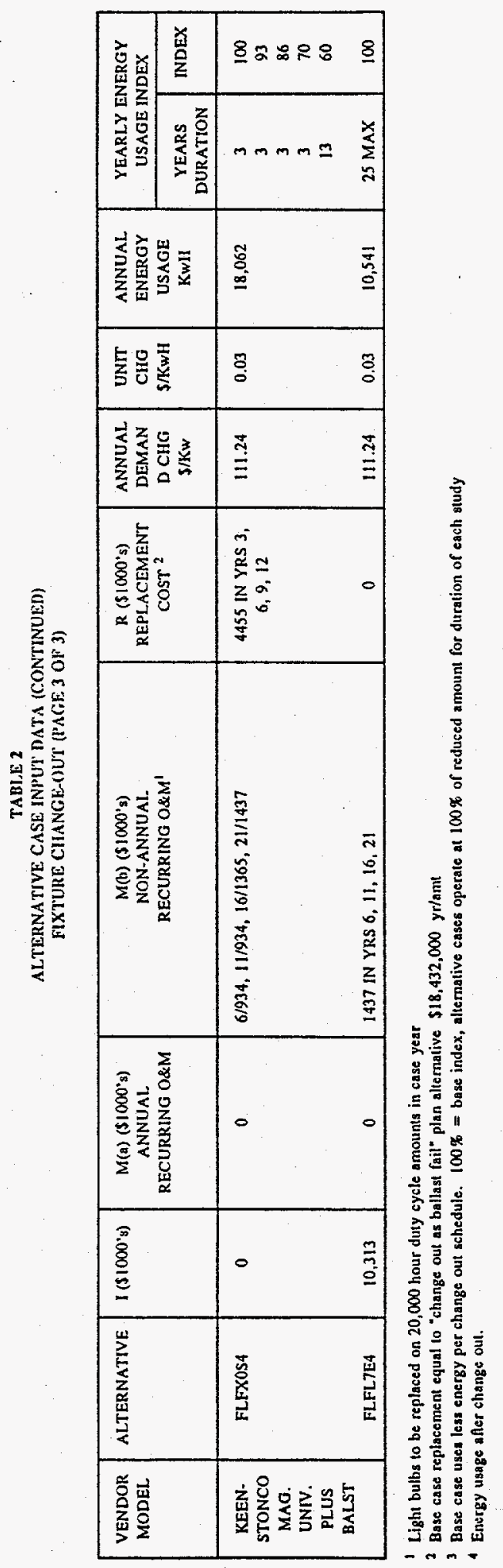

April 29, 1992 
TABLE 3. ALTERNATE BALLAST/FIXTURE INVESTMENT COSTS (1000s)

Alternate

Ballast

FLBX1XX

FLBX2XX

FLBX3XX

FLBX4XX

FLBX5XX

FLBX6XX

FLBX7XX

FLBX8XX

FLBX9XX

FLBX10XX

FLBX11XX

FLBX12XX

FLFX7E4 (1B2B**)

$$
\left(2 \mathrm{~B} 4 \mathrm{~B}^{* *}\right)
$$

Unit

Cost

$\$ 12.62$

24.47

32.00

28.00

28.00

9.33

11.28

20.00

12.62

13.10

14.25

22.50

36.74

50.58
Change* Net Investment

In Base

Cost

$\$ 8547$

$\$+557$

9104

$+912$

9459

$+723$

9270

$+723$

9270

$-155$

8392

$-63$

8484

$+347$

8894

0

8547

$+23$

8570

$+77$

8624

$+465$

9012

$+1766$

10,313

*Base alternate case is Remediation Plan for material, labor, and waste disposal of $\$ 8,542,000$. Alternate ballasts change material costs only as follows:

Change in Base Cost $=47,036$ ballasts $\left(B_{A}-B_{B}\right)$

$\mathrm{B}_{\mathrm{A}}=$ Alternate ballast

$\mathrm{B}_{\mathrm{B}}=\$ 12.62$ for ballast priced in Remediation Plan

$* *=$ ENERGY EFFICIENT BALLAST 
TABLE 4. EFFICACY FACTORS

FOR FLUORESCENT LAMP BALLASTS

As required by Public Law 100-357 - June 28, 1988

For Operation of:

(1) F40T12/RS Lamp

(2) F40T12/RS Lamps

(2) F96T12 Slimline Lamps

(2) F96T12/HO High Output Rapid Start Lamps
Ballast Input Voltage $60 \mathrm{~Hz}$

120

277

120

277

120

277

120

277

\section{Total Nominal Lamp Watts}

40

40

80

80

150

150

220

220

\section{Minimum Ballast} Efficacy Factor

1.805

1.805

1.060

1.050

0.570

0.570

0.390

0.390

Power Factor $(\mathrm{PF})=0.90$ Minimum

Specifically exempt are:

- ballasts designed for dimming.

- ballasts designed for use in ambient temperatures of $0^{\circ} \mathrm{F}$ or less.

- ballasts which have a power factor of less than $90 \%$ and are used in residential building of 3 stories or less.

Effective dates:

January 1, 1990 - only complying ballasts can be manufactured.

April 1, 1990 - only complying ballasts can be sold by ballast manufacturers.

April 1, 1990 - only complying ballasts can be incorporated into fixtures by the luminaire manufacturer. 
FIGURE B-1. TABULATION OF LOWEST LIFE CYCLE COSTS

AND NET SAVINGS PER CASE STUDY

(Thousands \$)

LBL5S3

$16,297^{*}$

$4,363^{* *}$

LBL5S4

18,212

5,087

LBL5S6

26,445

3,694

LBL7E3

15,606

5,054

LBL7E4

17,529

5,758

LBL7E6

25,465

4,674

LFL7EA

19,269

$-2769$
FLBM7S3

$\$ 14,988$

$\$ 4,318$

FLBM5S4

$\$ 16,798$

$\$ 4,945$

FLBM5S6

$\$ 24,194$

$\$ 3,407$

FLBM7E3

$\$ 14,321$

$\$ 4,996$

FLBM7E4

$\$ 16,116$

$\$ 5,627$

FLBM7E6

$\$ 23,197$

$\$ 4,404$

FLFLM7E4

$\$ 17,891$

$+2849$
FLBN7S3

$\$ 13,973$

$\$ 4,352$

FLBN5S4

$\$ 15,051$

$\$ 4,816$

FLBN5S6

$\$ 18,593$

$\$ 5,465$

FLBN7E3

$\$ 13,431$

$\$ 4,894$

FLBN7E4

$\$ 14,355$

$\$ 5,502$

FLBN7E6

$\$ 17,925$

$\$ 6,133$

FLFN7E4

$\$ 16,092$

$+2966$

EGEND:

ALLAST

LBXXXX.LOW - Lowest LCC Per Study Period LBXXXX.CMP - Comparative Economic Study

Study Period: $\mathrm{L}=25$ years

$M=20$ years

$\mathrm{N}=15$ years

$\mathrm{O}=10$ years

$\mathrm{P}=5$ years

$\mathrm{Q}=7$ years

*LCC Per Figures B-2 through B-31, \& B-56 through B-61

**NS Per Figures B-32 through B-55

FIXTURE

FLFXXXX.LOW - Lowest LCC Per Study Period FKFXXXX.CMP - Comparative Economic Study

Type Bulb: $\quad \mathbf{S}=$ Standard

$\mathrm{E}=$ Energy Efficient

Duty Cycle: $3=3,000$ hours/year

$4=4,000$ hours $/$ year

$6=6,000$ hours/year 
FIGURE B-2.

LIFE-CYCLE COST COMPARISON: FLBL5S3.LOW

COMPARATIVE PRESENT-VALUE COSTS OF ALTERNATIVE PROJECTS (Shown in ascending order of initial cost, * = lowest LCC)

\begin{tabular}{l}
\multicolumn{1}{c}{$\begin{array}{c}\text { PROJECT } \\
\text { NAME }\end{array}$} \\
\hline-1 FLBLOS3 \\
FLBL6S3 \\
FLBL7S3 \\
FLBL9S3 \\
FLBL1S3 \\
FLBL10S3 \\
FLBL11S3 \\
FLBL8S3 \\
FLBL12S3 \\
FLBL2S3 \\
FLBL4S3 \\
FLBL5S3 \\
FLBL3S3
\end{tabular}

ICC

FILENAME

-

FLBLOS 3

FLBL6S3

FLBL7S3

FLBL9S3

FLBL1S3

FLBL10S3

FLBLIIS 3

FLBL8S3

FLBL12S3

FLBL2S3

FLBL 4S 3

FLBL5S3

FLBL 353

\begin{tabular}{r} 
INITIAL \\
COST (PV) \\
\hline$\$ 8,023$ \\
$\$ 8,111$ \\
$\$ 8,171$ \\
$\$ 8,172$ \\
$\$ 8,193$ \\
$\$ 8,245$ \\
$\$ 8,503$ \\
$\$ 8,616$ \\
$\$ 8,704$ \\
$\$ 8,862$ \\
$\$ 8,862$ \\
$\$ 9,043$
\end{tabular}

IIFE CYCLE

$\operatorname{cosT}$ (PV)

$\$ 20,660$

$\$ 21,508$

$\$ 16,395$

$\$ 17,364$

$\$ 17,366$

$\$ 17,569$

$\$ 16,528$

$\$ 16,968$

$\$ 16,899$

$\$ 16,987$

$\$ 17,121$

$\$ 16,297$ *

$\$ 17,873$ 
FIGURE B-3.

IIFE-CYCLE COST COMPARISON: FLBM7S3.LOW

COMPARATIVE PRESENT-VALUE COSTS OF ALTERNATIVE PROJECTS (Shown in ascending order of initial cost, * = lowest ICC)

\begin{tabular}{l} 
PROJEC \\
NAME \\
\hline FLBMOS3 \\
FLBM6S3 \\
FLBM7S3 \\
FLBL9S3 \\
FLBM1S3 \\
FLBM1053 \\
FLBM1153 \\
FLBM8S3 \\
FLBM12S3 \\
FLBM2S3 \\
FLBM4S3 \\
FLBM5S3 \\
FLBM 353
\end{tabular}

\begin{tabular}{l}
$\quad$ LCC \\
FILENAME \\
\hline$--1--$ \\
FLBMOS3 \\
FLBM6S3 \\
FLBM7S3 \\
FLBM9S3 \\
FLBM1S3 \\
FLBM1OS3 \\
FLBM1153 \\
FLBM8S3 \\
FLBM 1253 \\
FLBM2S3 \\
FLBM4S3 \\
FLBM5S3 \\
FLBM 353
\end{tabular}

\begin{tabular}{rr}
\multicolumn{1}{c}{ INITIAI } \\
COST (PV) \\
\hdashline$\$ 0$ \\
$\$ 8,023$ \\
$\$ 8,111$ \\
$\$ 8,171$ \\
$\$ 8,172$ \\
$\$ 8,193$ \\
$\$ 8,245$ \\
$\$ 8,503$ \\
$\$ 8,616$ \\
$\$ 8,704$ \\
$\$ 8,862$ \\
$\$ 8,862$ \\
$\$ 9,043$
\end{tabular}

LIFE CYCLE $\operatorname{cosT}$ (PV)

$\$ 19,317$

$\$ 19,984$

$\$ 14,998 *$

$\$ 15,840$

$\$ 15,842$

$\$ 16,019$

$\$ 15,132$

$\$ 15,547$

$\$ 15,503$

$\$ 15,591$

$\$ 15,750$

$\$ 15,020$

$\$ 16,400$ 
FIGURE B-4.

LIFE-CYCLE COST COMPARISON: FLBN7S3.LOW

COMPARATIVE PRESENT-VALUE COSTS OF ALTERNATIVE PROJECTS

(Shown in ascending order of initial cost, * = lowest LCC)

$\quad \begin{aligned} & \text { PROJECT } \\ & \text { NAME }\end{aligned}$
FLBNOS3
FLBN6S3
FLBN7S3
FLBN9S3
FLBN1S3
FLBN1053
FLBN11S3
FLBN8S3
FLBN12S3
FLBN2S3
FLBN5S3
FLBN5S3
FLBN3S3

\begin{tabular}{l}
$\quad$ LCC \\
FILENAME \\
\hline FLBNOS3 \\
FLBN6S3 \\
FLBN753 \\
FLBN953 \\
FLBN1S3 \\
FLBN10S3 \\
FLBN11S3 \\
FLBN8S3 \\
FLBN1253 \\
FLBN2S3 \\
FLBN4S3 \\
FLBN5S3 \\
FLBN3S3
\end{tabular}

\begin{tabular}{r}
\multicolumn{2}{c}{ INITIAI } \\
COST (PV) \\
\hdashline$\$ 0$ \\
$\$ 8,023$ \\
$\$ 8,111$ \\
$\$ 8,171$ \\
$\$ 8,172$ \\
$\$ 8,193$ \\
$\$ 8,245$ \\
$\$ 8,503$ \\
$\$ 8,616$ \\
$\$ 8,704$ \\
$\$ 8,862$ \\
$\$ 8,862$ \\
$\$ 9,043$
\end{tabular}

\begin{tabular}{c} 
LIFE CYCLE \\
COST (PV) \\
\hline$\$ 18,325$ \\
$\$ 14,510$ \\
$\$ 13,973 *$ \\
$\$ 14,658$ \\
$\$ 14,659$ \\
$\$ 14,805$ \\
$\$ 14,106$ \\
$\$ 14,520$ \\
$\$ 14,477$ \\
$\$ 14,565$ \\
$\$ 14,724$ \\
$\$ 14,141$ \\
$\$ 15,280$
\end{tabular}


FIGURE B-5.

LIFE-CYCLE COST COMPARISON: FLBO7S3.LOW

COMPARATIVE PRESENT-VALUE COSTS OF ALTERNATIVE PROJECTS (Shown in ascending order of initial cost, * = lowest ICC)

\begin{tabular}{l}
$\quad$ PROJECT \\
NAME \\
\hline FLBOOS3 \\
FLBO6S3 \\
FLBO7S3 \\
FLBO9S3 \\
FLBO1S3 \\
FLBO1053 \\
FLBO11S3 \\
FLBO8S3 \\
FLBO12S3 \\
FLBO2S3 \\
FLBO4S3 \\
FLBO5S3 \\
FLBO3S3
\end{tabular}

\begin{tabular}{l}
\multicolumn{1}{c}{ LCC } \\
FILENAME \\
\hline FLBOOS3 \\
FLBO6S3 \\
FLBO7S3 \\
FLBO9S3 \\
FLBO1S3 \\
FLBO10S3 \\
FLBO1153 \\
FLBO8S3 \\
FLBO12S3 \\
FLBO2S3 \\
FLBO4S3 \\
FLBO5S3 \\
FLBO3S3
\end{tabular}

\begin{tabular}{r}
\multicolumn{1}{c}{ INITIAL } \\
COST (PV) \\
\hdashline$\$ 0$ \\
$\$ 8,023$ \\
$\$ 8,111$ \\
$\$ 8,171$ \\
$\$ 8,172$ \\
$\$ 8,193$ \\
$\$ 8,245$ \\
$\$ 8,503$ \\
$\$ 8,616$ \\
$\$ 8,704$ \\
$\$ 8,862$ \\
$\$ 8,862$ \\
$\$ 9,043$
\end{tabular}

\begin{tabular}{c} 
LIFE CYCLE \\
COST (PV) \\
\hdashline$\$ 14,349$ \\
$\$ 12,330$ \\
$\$ 11,980 *$ \\
$\$ 12,478$ \\
$\$ 12,480$ \\
$\$ 12,588$ \\
$\$ 12,114$ \\
$\$ 12,481$ \\
$\$ 12,485$ \\
$\$ 12,573$ \\
$\$ 12,732$ \\
$\$ 12,323$ \\
$\$ 13,175$
\end{tabular}


FIGURE B-6.

IIFE-CYCLE COST COMPARISON: FLBL5S4.LOW

COMPARATIVE PRESENT-VALUE COSTS OF ALTERNATIVE PROJECTS (Shown in ascending order of initial cost, * = lowest ICC)

$\quad \begin{gathered}\text { PROJECT } \\ \text { NAME }\end{gathered}$
FLBLOS4
FLBL6S4
FLBL754
FLBL9S4
FLBL1S4
FLBL10S4
FLBL11S4
FLBL8S4
FLBL12S4
FLBL2S4
FLBL4S4
FLBL5S4
FLBL3S4

ICC

FILENAME

FLBLOS4

FLBL6S4

FLBL7S4

FLBL9S4

FLBL1S4

FLBLIOS 4

FLBL11S4

FLBL8S4

FIBL12S 4

FLBL2S 4

FLBL4S 4

FLBL5S4

FLBL 354

\begin{tabular}{r} 
INITIAI \\
COST (PV) \\
\hdashline$\$ 0$ \\
$\$ 8,023$ \\
$\$ 8,111$ \\
$\$ 8,171$ \\
$\$ 8,172$ \\
$\$ 8,193$ \\
$\$ 8,245$ \\
$\$ 8,503$ \\
$\$ 8,616$ \\
$\$ 8,704$ \\
$\$ 8,862$ \\
$\$ 8,862$ \\
$\$ 9,043$
\end{tabular}

LIFE CYCLE

$\operatorname{cosT}$ (PV)

$\$ 23,299$

$\$ 19,718$

$\$ 18,593$

$\$ 19,866$

$\$ 19,867$

$\$ 20,131$

$\$ 18,726$

$\$ 19,227$

$\$ 19,097$

$\$ 19,185$

$\$ 19,344$

$\$ 18,212$ *

$\$ 20,253$ 


\section{FIGURE B-7.}

IIFE-CYCLE COST COMPARISON: FLBM5S4.LOW

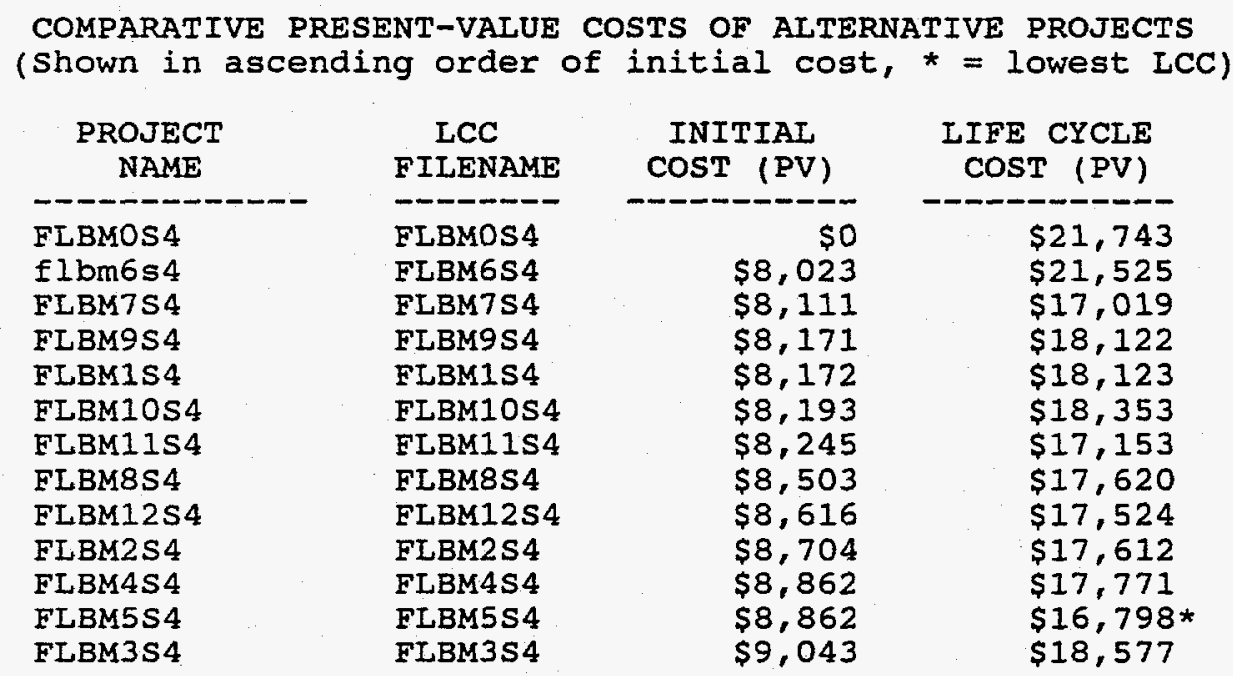


FIGURE B-8.

LIFE-CYCLE COST COMPARISON: FLBN5S4.LOW

COMPARATIVE PRESENT-VALUE COSTS OF ALTERNATIVE PROJECTS (Shown in ascending order of initial cost, * = lowest ICC)

\begin{tabular}{l}
$\begin{array}{c}\text { PROJECT } \\
\text { NAME }\end{array}$ \\
\hline FLBNOS4 \\
FLBN6S4 \\
FLBN7S4 \\
FLBN9S4 \\
FLBN1S4 \\
FLBN10S4 \\
FLBN11S4 \\
FLBN8S4 \\
FLBN12S4 \\
FLBN2S4 \\
FLBN4S4 \\
FLBN5S4 \\
FLBN3S4
\end{tabular}

LCC

FILENAME

DTONOS4

FLBN6S 4

FLBN7S4

FLBN9S4

FLBN1S4

FLBN10S4

FLBN11S4

FLBN8S4

FLBN 12S4

FLBN2S4

FLBN4S 4

FLBN5S4

FLBN3S 4

\begin{tabular}{r}
\multicolumn{1}{c}{ INITIAL } \\
COST (PV) \\
\hdashline$\$ 0$ \\
$\$ 8,023$ \\
$\$ 8,111$ \\
$\$ 8,171$ \\
$\$ 8,172$ \\
$\$ 8,193$ \\
$\$ 8,245$ \\
$\$ 8,503$ \\
$\$ 8,616$ \\
$\$ 8,704$ \\
$\$ 8,862$ \\
$\$ 8,862$ \\
$\$ 9,043$
\end{tabular}

\begin{tabular}{c} 
LIFE CYCLE \\
COST (PV) \\
\hline$\$ 19,857$ \\
$\$ 15,823$ \\
$\$ 15,077$ \\
$\$ 15,971$ \\
$\$ 15,972$ \\
$\$ 16,160$ \\
$\$ 15,211$ \\
$\$ 15,636$ \\
$\$ 15,582$ \\
$\$ 16,503$ \\
$\$ 15,829$ \\
$\$ 15,051 *$ \\
$\$ 16,510$
\end{tabular}


FIGURE B-9.

LIFE-CYCLE COST COMPARISON: FLBO5S4.LOW

COMPARATIVE PRESENT-VALUE COSTS OF ALTERNATIVE PROJECTS (Shown in ascending order of initial cost, * = lowest LCC)

\begin{tabular}{l}
$\quad \begin{array}{c}\text { PROJECT } \\
\text { NAME }\end{array}$ \\
\hline- \\
FLBOOS4 \\
FLBO6S4 \\
FLBO7S4 \\
FLBO1S4 \\
FLBO10S4 \\
FLBO9S4 \\
FLBO11S4 \\
FLBO8S4 \\
FLBO12 \\
FLBO2S4 \\
FLBO4S4 \\
FLBO5S4 \\
FLBO3S4
\end{tabular}

\begin{tabular}{l}
\multicolumn{1}{c}{ LCC } \\
FILENAME \\
\hline- \\
FLBO0S4 \\
FLBO6S4 \\
FLBO7S4 \\
FLBO1S4 \\
FLBO10S4 \\
FLBO9S4 \\
FLBO11S4 \\
FLBO8S4 \\
FLBO12S4 \\
FLBO2S4 \\
FLBO4S4 \\
FLBO5S4 \\
FLBO3S4
\end{tabular}

\begin{tabular}{r} 
INITIAL \\
COST (PV) \\
\hline$\$ \$ 0$ \\
$\$ 8,023$ \\
$\$ 8,111$ \\
$\$ 8,172$ \\
$\$ 8,193$ \\
$\$ 8,193$ \\
$\$ 8,245$ \\
$\$ 8,503$ \\
$\$ 8,616$ \\
$\$ 8,704$ \\
$\$ 8,862$ \\
$\$ 8,862$ \\
$\$ 9,043$
\end{tabular}

IIFE CYCLE $\operatorname{COST}(\mathrm{PV})$

$\$ 15,199$

$\$ 13,213$

$\$ 12,717 *$

$\$ 13,362$

$\$ 13,500$

$\$ 13,384$

$\$ 12,851$

$\$ 13,226$

$\$ 13,222$

$\$ 13,310$

$\$ 13,469$

$\$ 12,924$

$\$ 14,000$ 
FIGURE B-10.

IIFE-CYCLE COST COMPARISON: FLBL5S6.LOW

COMPARATIVE PRESENT-VALUE COSTS OF ALTERNATIVE PROJECTS (Shown in ascending order of initial cost, * = lowest LCC)

$\quad \begin{aligned} & \text { PROJECT } \\ & \text { NAME }\end{aligned}$
FLBLOS6
FLBL656
FLBL756
FLBL9S6
FLBL156
FLBL1056
FLBL1156
FLBL8S6
FLBL1256
FLBL256
FLBL4S6
FLBL5S6

\begin{tabular}{l}
\multicolumn{1}{c}{ ICC } \\
FILENAME \\
\hline$--1--$ \\
FLBLOS6 \\
FLBL6S6 \\
FLBL7S6 \\
FLBL9S6 \\
FLBL156 \\
FLBL1056 \\
FLBL1156 \\
FLBL856 \\
FLBL1256 \\
FLBL256 \\
FLBL456 \\
FLBL556
\end{tabular}

\begin{tabular}{r} 
INITIAL \\
COST (PV) \\
\hline$\$ 8,023$ \\
$\$ 8,111$ \\
$\$ 8,171$ \\
$\$ 8,172$ \\
$\$ 8,193$ \\
$\$ 8,245$ \\
$\$ 8,503$ \\
$\$ 8,616$ \\
$\$ 8,704$ \\
$\$ 8,862$ \\
$\$ 8,862$
\end{tabular}

LIFE CYCLE COST (PV)

$\$ 30,139$

$\$ 32,612$

$\$ 27,042$

$\$ 28,950$

$\$ 28,951$

$\$ 29,346$

$\$ 27,238$

$\$ 27,980$

$\$ 27,782$

$\$ 27,911$

$\$ 28,143$

$\$ 26,445 *$ 
FIGURE B-11.

IIFE-CYCLE COST COMPARISON: FLBM5S6.LOW

COMPARATIVE PRESENT-VALUE COSTS OF ALTERNATIVE PROJECTS (Shown in ascending order of initial cost, * = lowest ICC)

$\quad \begin{aligned} & \text { PROJECT } \\ & \text { NAME }\end{aligned}$
FLBMOS6
FLBM6S6
FLBM7S6
FLBM9S6
FLBM1S6
FLBM10S6
FLBM11S6
FLBM8S6
FLBM12S6
FLBM2S6
FLBM4S6
FLBM5S6
FLBM3S6

LCC

FILENAME

FLBMOS6

FIBM6S6

FLBM7S6

FLBM9S6

FLBM1S6

FLBM10S6

FLBM11S 6

FLBM8S6

FLBM 1256

FLBM2S6

FLBM 456

FLBM5S6

FLBM3S6

INITIAI
COST (PV)
$\$ \$ 0,023$
$\$ 8,111$
$\$ 8,171$
$\$ 8,172$
$\$ 8,193$
$\$ 8,245$
$\$ 8,503$
$\$ 8,616$
$\$ 8,704$
$\$ 8,862$
$\$ 8,862$
$\$ 9,043$

LIFE CYCLE $\operatorname{cosT}$ (PV)

$\$ 27,601$

$\$ 27,162$

$\$ 24,552$

$\$ 26,204$

$\$ 26,206$

$\$ 26,687$

$\$ 24,748$

$\$ 25,439$

$\$ 25,292$

$\$ 25,421$

$\$ 25,738$

$\$ 24,194$ *

$\$ 26,857$ 
FIGURE B-12.

LIFE-CYCLE COST COMPARISON: FIBN5S6.LOW

COMPARATIVE PRESENT-VALUE COSTS OF ALTERNATIVE PROJECTS (Shown in ascending order of initial cost, * = lowest ICC)

\begin{tabular}{l}
$\quad \begin{array}{c}\text { PROJECT } \\
\text { NAME }\end{array}$ \\
\hline FLBNOS6 \\
FLBN6S6 \\
FLBN7S6 \\
FLBN9S6 \\
FLBN1S6 \\
FLBN1056 \\
FLBN11S6 \\
FLBN8S6 \\
FLBN12S6 \\
FLBN2S6 \\
FLBN4S6 \\
FLBN5S6 \\
FLBN356
\end{tabular}

\begin{tabular}{l}
\multicolumn{1}{c}{ ICC } \\
FILENAME \\
\hline$---1-$ \\
FLBNOS6 \\
FLBN6S6 \\
FLBN7S6 \\
FLBN9S6 \\
FLBN1S6 \\
FLBN10S6 \\
FLBN11S6 \\
FLBN8S6 \\
FLBN12S6 \\
FLBN2S6 \\
FLBN4S6 \\
FLBN5S6 \\
FLBN3S6
\end{tabular}

\begin{tabular}{r} 
INITIAI \\
COST $(\mathrm{PV})$ \\
\hline$\$ 8,023$ \\
$\$ 8,111$ \\
$\$ 8,171$ \\
$\$ 8,172$ \\
$\$ 8,193$ \\
$\$ 8,245$ \\
$\$ 8,503$ \\
$\$ 8,616$ \\
$\$ 8,704$ \\
$\$ 8,862$ \\
$\$ 8,862$ \\
$\$ 9,043$
\end{tabular}

\begin{tabular}{c} 
LIFE CYCLE \\
COST (PV) \\
\hline$\$ 24,058$ \\
$\$ 24,412$ \\
$\$ 19,009$ \\
$\$ 20,319$ \\
$\$ 20,320$ \\
$\$ 20,591$ \\
$\$ 19,142$ \\
$\$ 19,651$ \\
$\$ 19,513$ \\
$\$ 19,601$ \\
$\$ 19,760$ \\
$\$ 18,593 *$ \\
$\$ 20,691$
\end{tabular}


FIGURE B-13.

LIFE-CYCLE COST COMPARISON: FLBO5S6.IOW

COMPARATIVE PRESENT-VALUE COSTS OF ALTERNATIVE PROJECTS (Shown in ascending order of initial cost, * = lowest ICC)

$\quad \begin{gathered}\text { PROJECT } \\ \text { NAME }\end{gathered}$
FLBO0S6
FLBO6S6
FLBO7S6
FLBO9S6
FLBO1S6
FLBO1056
FLBO11S6
FLBO8S6
FLBO1256
FLBO2S6
FLBO4S6
FLBO5S6
FLBO3S6

\begin{tabular}{l}
\multicolumn{1}{c}{ LCC } \\
FILENAME \\
----- \\
FLBO0S6 \\
FLBO6S6 \\
FLBO7S6 \\
FLBO9S6 \\
FLBO1S6 \\
FLBO1056 \\
FLBO11S6 \\
FLBO8S6 \\
FLBO1256 \\
FLBO2S6 \\
FLBO4S6 \\
FLBO5S6 \\
FLBO3S6
\end{tabular}

\begin{tabular}{c} 
LIFE CYCLE \\
COST (PV) \\
\hdashline$\$ 18,703$ \\
$\$ 15,978$ \\
$\$ 15,254$ \\
$\$ 16,189$ \\
$\$ 16,190$ \\
$\$ 16,387$ \\
$\$ 15,387$ \\
$\$ 15,821$ \\
$\$ 15,758$ \\
$\$ 15,846$ \\
$\$ 16,005$ \\
$\$ 15,188 *$ \\
$\$ 16,711$
\end{tabular}


FIGURE B-14.

LIFE-CYCLE COST COMPARISON: FLBL7E3.LOW

COMPARATIVE PRESENT-VALUE COSTS OF ALTERNATIVE PROJECTS

(Shown in ascending order of initial cost, * = lowest LCC)

$\quad \begin{aligned} & \text { PROJECT } \\ & \text { NAME }\end{aligned}$
FLBLOS3
FLBL6E3
FLBL 7E3
FLBL9E3
FLBL1E3
FLBL1OE3
FLBL11E3
FLBL8E3
FLBL12E3
FLBL2E3
FLBL4E3
FLBL5E3
FLBL 3E3

LCC

FILENAME

-

FLBLOS 3

FLBL 7E3

FLBL9E3

FLBL1E3

FLBL1OE3

FLBL11E3

FLBL8E3

FLBL12E3

FLBL2E 3

FLBI 4E 3

FLBL5E 3

FLBL $3 E 3$

INITIAI
COST (PV)
$\$ 8,023$
$\$ 8,111$
$\$ 8,171$
$\$ 8,172$
$\$ 8,193$
$\$ 8,245$
$\$ 8,503$
$\$ 8,616$
$\$ 8,704$
$\$ 8,862$
$\$ 8,862$
$\$ 9,043$

LIFE CYCLE

COST (PV)

$\$ 20,660$

$\$ 21,205$

$\$ 15,606 *$

$\$ 16,394$

$\$ 16,516$

$\$ 16,659$

$\$ 15,740$

$\$ 16,301$

$\$ 16,050$

$\$ 16,199$

$\$ 16,418$

$\$ 16,115$

$\$ 17,024$ 
FIGURE B-15.

LIFE-CYCLE COST COMPARISON: FLBM7E3.LOW

COMPARATIVE PRESENT-VALUE COSTS OF ALTERNATIVE PROJECTS (Shown in ascending order of initial cost, * = lowest LCC)

\section{PROJECT NAME}

FLBMOS 3

FLBM6E3

FLBM7E3

FLBM9E 3

FLBM1E3

FLBM $10 E 3$

FLBM11E3

FLBM8E3

FLBM12E3

FLBM2E 3

FLBM 4 E 3

FLBM5E3

FLBM $3 E 3$
LCC FILENAME

FLBMOS 3

FLBM6E 3

FLBM7E 3

FLBM9E3

FLBM1E3

FLBM1OE3

FLBM11E3

FLBM8E 3

FLBM12E3

FLBM2E 3

FLBM4E3

FLBM5E3

FLBM $3 E 3$

\begin{tabular}{r} 
INITIAL \\
COST. (PV) \\
\hdashline$\$ 0$ \\
$\$ 8,023$ \\
$\$ 8,111$ \\
$\$ 8,171$ \\
$\$ 8,172$ \\
$\$ 8,193$ \\
$\$ 8,245$ \\
$\$ 8,503$ \\
$\$ 8,616$ \\
$\$ 8,704$ \\
$\$ 8,862$ \\
$\$ 8,862$ \\
$\$ 9,043$
\end{tabular}

LIFE CYCLE COST (PV)

$\$ 19,317$

$\$ 19,723$

$\$ 14,321 *$

$\$ 15,007$

$\$ 15,112$

$\$ 15,237$

$\$ 14,455$

$\$ 14,974$

$\$ 14,774$

$\$ 14,914$

$\$ 15,124$

$\$ 14,864$

$\$ 15,670$ 
FIGURE B-16.

LIFE-CYCLE COST COMPARISON: FLBN7E3.LOW

COMPARATIVE PRESENT-VALUE COSTS OF ALTERNATIVE PROJECTS

(Shown in ascending order of initial cost, * = lowest LCC)

$\quad \begin{aligned} & \text { PROJECT } \\ & \text { NAME }\end{aligned}$
FLBNOS3
FLBN6E3
FLBN7E3
FLBN9E3
FLBN1E3
FLBN10E3
FLBN11E3
FLBN8E3
FLBN12E3
FLBL2E3
FLBN4E3
FLBN5E3
FLBN3E3

\begin{tabular}{l} 
LCC \\
FILENAME \\
\hline FLBNOS3 \\
FLBN6E3 \\
FLBN7E3 \\
FLBN9E3 \\
FLBN1E3 \\
FLBN10E3 \\
FLBN11E3 \\
FLBN8E3 \\
FLBN12E3 \\
FLBN2E3 \\
FLBN4E3 \\
FLBN5E3 \\
FLBN3E3
\end{tabular}

\begin{tabular}{r} 
INITIAL \\
COST (PV) \\
\hline$\$ 8,023$ \\
$\$ 8,111$ \\
$\$ 8,171$ \\
$\$ 8,172$ \\
$\$ 8,193$ \\
$\$ 8,245$ \\
$\$ 8,503$ \\
$\$ 8,616$ \\
$\$ 8,704$ \\
$\$ 8,862$ \\
$\$ 8,862$ \\
$\$ 9,043$
\end{tabular}

LIFE CYCLE $\operatorname{cosT}(P V)$

$\$ 18,325$

$\$ 14,301$

$\$ 13,431 *$

$\$ 13,991$

$\$ 14,075$

$\$ 14,180$

$\$ 13,565$

$\$ 14,031$

$\$ 13,894$

$\$ 14,023$

$\$ 14,224$

$\$ 14,015$

$\$ 14,696$ 
FIGURE B-17.

LIFE-CYCLE COST COMPARISON: FLBO7E3. LOW

COMPARATIVE PRESENT-VALUE COSTS OF ALTERNATIVE PROJECTS

(Shown in ascending order of initial cost, * = lowest ICC)

\begin{tabular}{l}
$\begin{array}{c}\text { PROJECT } \\
\text { NAME }\end{array}$ \\
\hline FLBOOS3 \\
FLBO6E3 \\
FLBO7E3 \\
FLBO9E3 \\
FLBO9E4 \\
FLBO1E3 \\
FLBO10E3 \\
FLBO11E3 \\
FLBO8E3 \\
FLBO12E3 \\
FLBO2E3 \\
FLBO4E3 \\
FLBO5E3 \\
FLBO3E3
\end{tabular}

\begin{tabular}{l}
\multicolumn{1}{c}{ LCC } \\
FILENAME \\
\hline FLBO0S3 \\
FLBO6E3 \\
FLBO7E3 \\
FLBO9E3 \\
FLBO9E4 \\
FLBO1E3 \\
FLBO10E3 \\
FLBO11E3 \\
FLBO8E3 \\
FLBO12E3 \\
FLBO2E3 \\
FLBO4E3 \\
FLBO5E3 \\
FLBO3E3
\end{tabular}

\begin{tabular}{r}
\multicolumn{1}{c}{ INITIAL } \\
COST $(\mathrm{PV})$ \\
$\$ \$ 0$ \\
$\$ 8,023$ \\
$\$ 8,111$ \\
$\$ 8,171$ \\
$\$ 8,171$ \\
$\$ 8,172$ \\
$\$ 8,193$ \\
$\$ 8,245$ \\
$\$ 8,503$ \\
$\$ 8,616$ \\
$\$ 8,704$ \\
$\$ 8,862$ \\
$\$ 8,862$ \\
$\$ 9,043$
\end{tabular}

IIFE CYCLE $\operatorname{cosT}(\mathrm{PV})$

$\$ 14,349$

$\$ 12,184$

$\$ 11,601 *$

$\$ 12,012$

$\$ 12,739$

$\$ 12,071$

$\$ 12,150$

$\$ 11,735$

$\$ 12,139$

$\$ 12,077$

$\$ 12,194$

$\$ 12,382$

$\$ 12,236$

$\$ 12,767$ 
FIGURE B-18.

LIFE-CYCLE COST COMPARISON: FLBP7E3.LOW

COMPARATIVE PRESENT-VALUE COSTS OF ALTERNATIVE PROJECTS

(Shown in ascending order of initial cost, * = lowest ICC)

PROJECT NAME

FLBPOS 3

FLBP7E3
LCC

FILENAME

FLBPOS 3

FLBP7E3

\author{
INITIAL \\ $\operatorname{cosT}$ (PV) \\ so \\ $\$ 8,111$
}

LIFE CYCLE $\operatorname{cosT}(P V)$

$\$ 5,792$ * $\$ 9,427$ 
FIGURE B-19.

LIFE-CYCLE COST COMPARISON: FLBQ7E3.LOW

COMPARATIVE PRESENT-VALUE COSTS OF ALTERNATIVE PROJECTS (Shown in ascending order of initial cost, * = lowest LCC)

\begin{tabular}{|c|c|}
\hline $\begin{array}{c}\text { PROJECT } \\
\text { NAME }\end{array}$ & $\begin{array}{c}\text { LCC } \\
\text { FILENAME }\end{array}$ \\
\hline $\begin{array}{l}\text { FLBQOS3 } \\
\text { FLBO7E3 }\end{array}$ & $\begin{array}{l}\text { FLBQOS3 } \\
\text { FLBO7E3 }\end{array}$ \\
\hline
\end{tabular}

INITIAI
$\operatorname{cosT}(\mathrm{PV})$
$\mathbf{\$ 8 , 1 1 1}$

LIFE CYCLE $\operatorname{cosT}(\mathrm{PV})$

FLBQ7E3

FLBQ7E3

$\$ 8,111$

$\$ 9,750 *$

$\$ 9,876$ 
FIGURE B-20.

IIFE-CYCLE COST COMPARISON: FLBL7E4.LOW

COMPARATIVE PRESENT-VALUE COSTS OF ALTERNATIVE PROJECTS (Shown in ascending order of initial cost, * = lowest LCC)

\begin{tabular}{|c|c|}
\hline $\begin{array}{l}\text { PROJECT } \\
\text { NAME }\end{array}$ & $\begin{array}{c}\text { LCC } \\
\text { FILENAME }\end{array}$ \\
\hline ーーーーーーーーー & 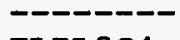 \\
\hline FLBLOS4 & FLBLOS 4 \\
\hline FLBL6E4 & FIBL6E4 \\
\hline FLBL 7E4 & FLBL 7E 4 \\
\hline FLBL1E4 & FLBL1E4 \\
\hline FLBL1OE4 & FLBL 10E4 \\
\hline FLBL1 1E4 & FLBL $11 E 4$ \\
\hline FLBL8E4 & FLBL8E4 \\
\hline FLBL $12 E 4$ & FLBL 12E 4 \\
\hline FLBL 2E4 & FLBL $2 E 4$ \\
\hline FLBL $4 E 4$ & FLBL $4 E 4$ \\
\hline FLBL 5E 4 & FLBL 5E4 \\
\hline FLBL $3 E 4$ & FLBL $3 E 4$ \\
\hline
\end{tabular}

INITIAI
COST (PV)
$-\$ 0$
$\$ 8,023$
$\$ 8,111$
$\$ 8,172$
$\$ 8,193$
$\$ 8,245$
$\$ 8,503$
$\$ 8,616$
$\$ 8,704$
$\$ 8,862$
$\$ 8,862$
$\$ 9,043$

\begin{tabular}{c} 
LIFE CYCLE \\
COST (PV) \\
\hline$\$ 23,099$ \\
$\$ 22,849$ \\
$\$ 17,529 *$ \\
$\$ 18,721$ \\
$\$ 18,903$ \\
$\$ 17,663$ \\
$\$ 18,325$ \\
$\$ 17,954$ \\
$\$ 18,122$ \\
$\$ 18,362$ \\
$\$ 17,958$ \\
$\$ 19,107$
\end{tabular}


FIGURE B-21

LIFE-CYCLE COST COMPARISON: FLBM7E4.LOW

COMPARATIVE PRESENT-VALUE COSTS OF ALTERNATIVE PROJECTS (Shown in ascending order of initial cost, * = lowest LCC)

$\quad \begin{array}{r}\text { PROJECT } \\ \text { NAME }\end{array}$
FLBMOS4
FLBM6E4
FIBM7E4
FLBM1E4
FLBM9E4
FLBM1OE4
FLBM11E4
FLBM8E4
FLBM12E4
FLBM2E4
FLBM4E4
FLBM5E4
FLBM3E4

$\quad$ LCC
FILENAME
FLBMOS4
FLBM6E4
FLBM7E4
FLBM1E4
FLBM9E4
FLBMIOE4
FLBM11E4
FLBM8E4
FLBM12E4
FLBM2E4
FLBM4E4
FLBM5E4
FLBM3E4

INITIAL
COST (PV)
$\$ \$ 8,023$
$\$ 8,111$
$\$ 8,169$
$\$ 8,171$
$\$ 8,193$
$\$ 8,245$
$\$ 8,503$
$\$ 8,616$
$\$ 8,704$
$\$ 8,862$
$\$ 8,862$
$\$ 9,043$

\begin{tabular}{c} 
LIFE CYCLE \\
COST (PV) \\
\hline$\$ 21,743$ \\
$\$ 21,178$ \\
$\$ 16,116 *$ \\
$\$ 17,147$ \\
$\$ 17,010$ \\
$\$ 17,310$ \\
$\$ 16,250$ \\
$\$ 16,855$ \\
$\$ 16,551$ \\
$\$ 16,708$ \\
$\$ 16,937$ \\
$\$ 16,589$ \\
$\$ 17,604$
\end{tabular}


FIGURE B-22.

LIFE-CYCLE COST COMPARISON: FLBN7E4.LOW

COMPARATIVE PRESENT-VALUE COSTS OF ALTERNATIVE PROJECTS (Shown in ascending order of initial cost, * = lowest LCC)

$\quad \begin{gathered}\text { PROJECT } \\ \text { NAME }\end{gathered}$
FLBNOS4
FLBN6E4
FLBN9E4
FLBN7E4
FLBN1E4
FLBN10E4
FLBN11E4
FLBN8E4
FLBN12E4
FLBN2E4
FLBN4E4
FLBN5E4
FLBN3E4

$\quad$ LCC
FILENAME
------
FLBNOS4
FLBN6E4
FLBN9E4
FLBN7E4
FLBN1E4
FLBN1OE4
FLBN11E4
FLBN8E4
FLBN12E4
FLBN2E4
FLBN4E4
FLBN5E4
FLBN3E4

INITIAL
COST (PV)
$-\$ 0$
$\$ 8,023$
$\$ 8,085$
$\$ 8,111$
$\$ 8,172$
$\$ 8,193$
$\$ 8,245$
$\$ 8,503$
$\$ 8,616$
$\$ 8,704$
$\$ 8,862$
$\$ 8,862$
$\$ 9,043$

\begin{tabular}{c}
$\begin{array}{c}\text { LIFE CYCLE } \\
\text { COST (PV) }\end{array}$ \\
\hdashline$\$ 19,857$ \\
$\$ 15,545$ \\
$\$ 14,996$ \\
$\$ 14,355$ \\
$\$ 15,194$ \\
$\$ 15,326$ \\
$\$ 14,488$ \\
$\$ 15,025$ \\
$\$ 14,804$ \\
$\$ 14,947$ \\
$\$ 15,162$ \\
$\$ 14,884$ \\
$\$ 15,731$
\end{tabular}


FIGURE B-23.

LIFE-CYCLE COST COMPARISON: FLBO7E4.LOW

COMPARATIVE PRESENT-VALUE COSTS OF ALTERNATIVE PROJECTS (Shown in ascending order of initial cost, * = lowest LCC)

$\quad \begin{aligned} & \text { PROJECT } \\ & \text { NAME }\end{aligned}$
FLBOOS4
FLBO6E4
FLBO7E4
FLBO9E4
FLBO1E4
FLBO1OE4
FLBO11E4
FLBO8E4
FLBO12E4
FLBO2E4
FLBO4E4
FLBO5E4
FLBO3E4

\begin{tabular}{l}
\multicolumn{1}{c}{ LCC } \\
FILENAME \\
\hline$--D L B O-$ \\
FLBOS4 \\
FLBO7E4 \\
FLBO9E4 \\
FLBO1E4 \\
FLBO10E4 \\
FLBO11E4 \\
FLBO8E4 \\
FLBO12E4 \\
FLBO2E4 \\
FLBO4E4 \\
FLBO5E4 \\
FLBO3E4
\end{tabular}

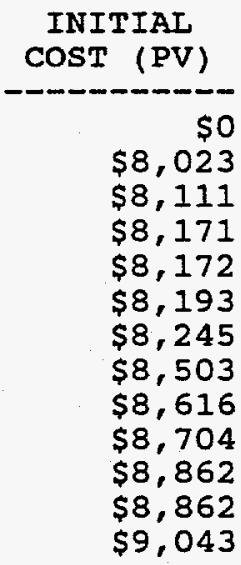

\begin{tabular}{c} 
LIFE CYCLE \\
COST (PV) \\
\hline$\$ 12,260$ \\
$\$ 13,019$ \\
$\$ 12,211 *$ \\
$\$ 12,739$ \\
$\$ 12,818$ \\
$\$ 12,916$ \\
$\$ 12,345$ \\
$\$ 12,798$ \\
$\$ 12,677$ \\
$\$ 12,804$ \\
$\$ 13,002$ \\
$\$ 12,807$ \\
$\$ 13,455$
\end{tabular}


FIGURE B-24.

LIFE-CYCLE COST COMPARISON: FLBP7E4. LOW

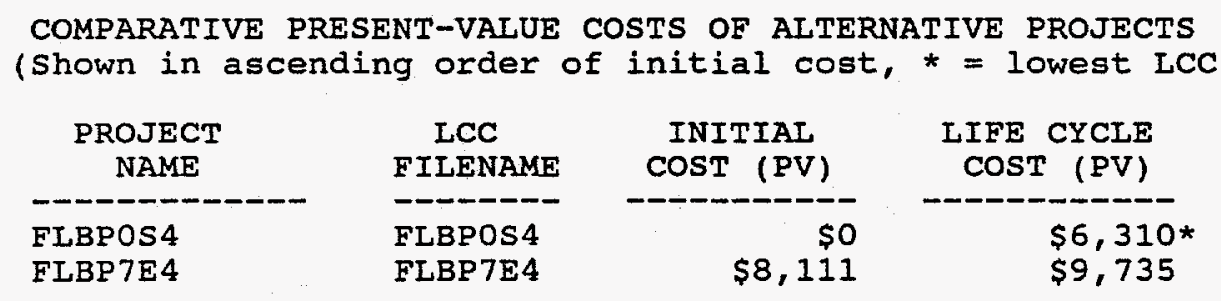


FIGURE B-25.

LIFE-CYCLE COST COMPARISON: FLBQ7E4.LOW

COMPARATIVE PRESENT-VALUE COSTS OF ALTERNATIVE PROJECTS

(Shown in ascending order of initial cost, * = lowest LCC)

\begin{tabular}{|c|c|c|c|}
\hline PROJECT & LCC & INITIAI & LIFE CYCLE \\
\hline NAME & FILENAME & $\operatorname{cosT}(\mathrm{PV})$ & $\operatorname{cosT}(\mathrm{PV})$ \\
\hline $\begin{array}{l}\text { FLBQOS } 4 \\
\text { FLBQ7E4 }\end{array}$ & $\begin{array}{l}\text { FLBQOS4 } \\
\text { FLBQ7E4 }\end{array}$ & $\begin{array}{r}\$ 0 \\
\$ 8,111\end{array}$ & $\begin{array}{l}\$ 11,362 * \\
\$ 11,486\end{array}$ \\
\hline
\end{tabular}


FIGURE B-26.

LIFE-CYCLE COST COMPARISON: FLBL7E6.LOW

COMPARATIVE PRESENT-VALUE COSTS OF ALTERNATIVE PROJECTS (Shown in ascending order of initial cost, * = lowest LCC)

$\begin{gathered}\text { PROJECT } \\ \text { NAME }\end{gathered}$
FLBMOS6
FLBM6E6
FLBM7E6
FLBM9E6
FLBM1E6
FLBM10E6
FLBM11E6
FLBM8E6
FLBM12E6
FLBM2E6
FLBM4E6
FLBM5E6
FLBM3E6

\begin{tabular}{l}
\multicolumn{1}{c}{ LCC } \\
FILENAME \\
\hline-----5 \\
FLBMOS6 \\
FLBM6E6 \\
FLBM7E6 \\
FLBM9E6 \\
FLBM1E6 \\
FLBM10E6 \\
FLBM11E6 \\
FLBM8E6 \\
FLBM12E6 \\
FLBM2E6 \\
FLBM4E6 \\
FLBM5E6 \\
FLBM3E6
\end{tabular}

\begin{tabular}{rr} 
INITIAL \\
COST (PV) \\
\hdashline$\$ 0$ \\
$\$ 8,023$ \\
$\$ 8,111$ \\
$\$ 8,171$ \\
$\$ 8,172$ \\
$\$ 8,193$ \\
$\$ 8,245$ \\
$\$ 8,503$ \\
$\$ 8,616$ \\
$\$ 8,704$ \\
$\$ 8,862$ \\
$\$ 8,862$ \\
$\$ 9,043$
\end{tabular}

\begin{tabular}{c} 
LIFE CYCLE \\
COST (PV) \\
\hline$\$ 27,601$ \\
$\$ 25,466$ \\
$\$ 23,197 *$ \\
$\$ 24,536$ \\
$\$ 24,746$ \\
$\$ 24,986$ \\
$\$ 23,393$ \\
$\$ 24,293$ \\
$\$ 23,833$ \\
$\$ 24,066$ \\
$\$ 24,403$ \\
$\$ 23,881$ \\
$\$ 25,397$
\end{tabular}


FIGURE B-27.

LIFE-CYCLE COST COMPARISON: FLBM7E6. LOW

COMPARATIVE PRESENT-VALUE COSTS OF ALTERNATIVE PROJECTS (Shown in ascending order of initial cost, * = lowest LCC)

\begin{tabular}{l}
\multicolumn{1}{c}{$\begin{array}{c}\text { PROJECT } \\
\text { NAME }\end{array}$} \\
\hline FLBMOS6 \\
FLBM6E6 \\
FLBM7E6 \\
FLBM9E6 \\
FLBM1E6 \\
FLBM10E6 \\
FLBM11E6 \\
FLBM8E6 \\
FLBM12E6 \\
FLBM2E6 \\
FLBM4E6 \\
FLBM5E6 \\
FLBM3E6
\end{tabular}

\begin{tabular}{l}
\multicolumn{1}{c}{ LCC } \\
FILENAME \\
\hline----- \\
FLBMOS6 \\
FLBM6E6 \\
FLBM7E6 \\
FLBM9E6 \\
FLBM1E6 \\
FLBM10E6 \\
FLBM11E6 \\
FLBM8E6 \\
FLBM12E6 \\
FLBM2E6 \\
FLBM4E6 \\
FLBM5E6 \\
FLBM3E6
\end{tabular}

\begin{tabular}{r} 
INITIAL \\
COST $(P V)$ \\
\hline$\$ 8,023$ \\
$\$ 8,111$ \\
$\$ 8,171$ \\
$\$ 8,172$ \\
$\$ 8,193$ \\
$\$ 8,245$ \\
$\$ 8,503$ \\
$\$ 8,616$ \\
$\$ 8,704$ \\
$\$ 8,862$ \\
$\$ 8,862$ \\
$\$ 9,043$
\end{tabular}

\begin{tabular}{c} 
LIFE CYCLE \\
COST (PV) \\
\hline$\$ 27,601$ \\
$\$ 25,466$ \\
$\$ 23,197 *$ \\
$\$ 24,536$ \\
$\$ 24,746$ \\
$\$ 24,986$ \\
$\$ 23,393$ \\
$\$ 24,293$ \\
$\$ 23,833$ \\
$\$ 24,066$ \\
$\$ 24,403$ \\
$\$ 23,881$ \\
$\$ 25,397$
\end{tabular}


FIGURE B-28.

LIFE-CYCLE COST COMPARISON: FLBN7E6.LOW

COMPARATIVE PRESENT-VALUE COSTS OF ALTERNATIVE PROJECTS (Shown in ascending order of initial cost, * = lowest LCC)

PROJECT

NAME

FLBNOS6

FLBN6E6

FLBN7E6

FLBN9E6

FLBN1E6

FLBN10E6

FLBN $11 E 6$

FLBN8E6

FLBN12E6

FLBN2E6

FLBN4E6

FLBN5E6

FLBN $3 E 6$
LCC

FILENAME

FLBNOS6

FLBN6E6

FLBN7E6

FLBN9E6

FLBN1E6

FLBN 10E6

FLBN11E6

FLBN8E6

FLBN 12E6

FLBN2E6

FLBN4E6

FLBN5E6

FLBN3E6

INITIAL
COST (PV)

$\$ 8,023$
$\$ 8,111$
$\$ 8,171$
$\$ 8,172$
$\$ 8,193$
$\$ 8,245$
$\$ 8,503$
$\$ 8,616$
$\$ 8,704$
$\$ 8,862$
$\$ 8,862$
$\$ 9,043$

IIFE CYCLE $\operatorname{cosT}$ (PV)

$\$ 24,058$

$\$ 19,754$

$\$ 17,925 *$

$\$ 18,985$

$\$ 19,153$

$\$ 19,341$

$\$ 18,059$

$\$ 18,734$

$\$ 18,346$

$\$ 18,518$

$\$ 18,760$

$\$ 18,343$

$\$ 19,524$ 
FIGURE B-29.

LIFE-CYCLE COST COMPARISON: FLBO7E6.LOW

COMPARATIVE PRESENT-VALUE COSTS OF ALTERNATIVE PROJECTS (Shown in ascending order of initial cost, * = lowest LCC)

\begin{tabular}{l} 
PROJECT \\
NAME \\
\hline FLBO056 \\
FLBO6E6 \\
FLBO7E6 \\
FLBO9E6 \\
FLBO1E6 \\
FLBO10E6 \\
FLBO11E6 \\
FLBO8E6 \\
FLBO12E6 \\
FLBO2E6 \\
FLBO4E6 \\
FLBO5E6 \\
FLBO3E6
\end{tabular}

$\quad$ LCC
FILENAME
F-----
FLBO0S6
FLBO6E6
FLBO7E6
FLBO9E6
FLBO1E6
FLBO1OE6
FLBO11E6
FLBO8E6
FLBO12E6
FLBO2E6
FLBO4E6
FLBO5E6
FLBO3E6

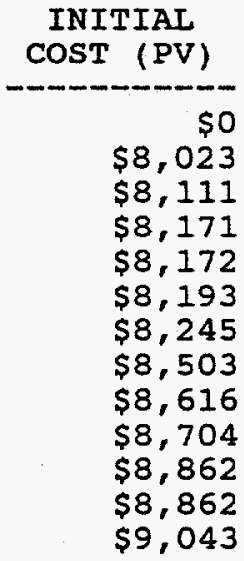

\begin{tabular}{c} 
LIFE CYCIE \\
COST (PV) \\
\hline$\$ 18,703$ \\
$\$ 15,750$ \\
$\$ 14,495 *$ \\
$\$ 15,255$ \\
$\$ 15,373$ \\
$\$ 15,511$ \\
$\$ 14,628$ \\
$\$ 15,178$ \\
$\$ 14,941$ \\
$\$ 15,087$ \\
$\$ 15,304$ \\
$\$ 15,013$ \\
$\$ 15,894$
\end{tabular}


FIGURE B-30.

LIFE-CYCLE COST COMPARISON: FLBP7E6.LOW

COMPARATIVE PRESENT-VALUE COSTS OF ALTERNATIVE PROJECTS
(ShOWn in ascending order of initial cost, * = lowest LCC)
\begin{tabular}{cccc} 
PROJECT & LCC & INITIAL & LIFE CYCLE \\
NAME & FILENAME & COST (PV) & COST (PV) \\
\hline FLBPOS6 & FLBPOS6 & SO & $\$ 8,248 *$ \\
FLBP7E6 & FLBP7E6 & $\$ 8,111$ & $\$ 11,551$
\end{tabular}


FIGURE B-31.

LIFE-CYCLE COST COMPARISON: FLBQ7E6.LOW

COMPARATIVE PRESENT-VALUE COSTS OF ALTERNATIVE PROJECTS

(Shown in ascending order of initial cost, * = lowest LCC)

\begin{tabular}{llrr}
$\begin{array}{c}\text { PROJECT } \\
\text { NAME }\end{array}$ & $\begin{array}{c}\text { LCC } \\
\text { FILENAME }\end{array}$ & $\begin{array}{r}\text { INITIAL } \\
\text { COST (PV) }\end{array}$ & \multicolumn{1}{c}{ LIFE CYCLT } \\
- COS
\end{tabular}


FIGURE B-32.

NIST BLCC: COMPARATIVE ECONOMIC ANALYSIS: FLBL7E3.CMP

BASE CASE: FLBLOS3

ALTERNATIVE: FLBL7E3

PRINCIPAL STUDY PARAMETERS:

ANALYSIS TYPE: Federal Analysis--Energy Conservation Projects STUDY PERIOD: 25 YEARS (1991 THROUGH 2015)

PLAN/CONSTR. PERIOD: 1 YEARS (1991 THROUGH 1991)

OCCUPANCY PERIOD: 24 YEARS (1992 THROUGH 2015)

DISCOUNT RATE: $4.6 \%$ Real (exclusive of general inflation)

BASE CASE LCC FILE: FLBLOS3. LCC

ALTERNATIVE LCC FILE: FLBL7E3. LCC

COMPARISON OF PRESENT-VALUE COSTS

INITIAL INVESTMENT ITEM(S):

CASH REQUIREMENTS AS OF OCCUPANCY

SUBTOTAL

FUTURE COST ITEMS:

ANNUAL AND NON-AN. RECURRING COSTS

ENERGY EXPENDITURES

REPLACEMENTS TO CAPITAL

SUBTOTAL

TOTAL P.V. LIFE-CYCLE COST

\section{BASE CASE:} FLBLOS3

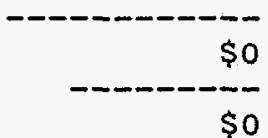

$\$ 0$

$\begin{array}{r}\$ 1,455 \\ \$ 6,486 \\ \$ 12,720 \\ \hline \$ 20,660 \\ \hline \$ 20,660\end{array}$

ALTERNATIVE: FLBL7E3

$-\cdots--\cdots---$

$\$ 8,111$

$\$ 8,111$

$\$ 2,327$

$\$ 5,168$

$\$ 0$

$\$ 7,495$

$\$ 15,606$
SAVINGS FROM AIT.

$-\$ 8,111$ $-$

$-\$ 8,111$

$-\$ 873$

$\$ 1,318$

$\$ 12,720$

$\$ 13,165$

$\$ 5,054$

SAVINGS-TO-INVESTMENT RATIO (SIR)

FOR PROJECT FLBL7E3 COMPARED TO PROJECT FLBLOS 3

$$
\mathrm{SIR}=\frac{\mathrm{P} . \mathrm{V} . \text { of non-investment savings }}{\text { Increased total investment }}=-0.10
$$


FIGURE B-33.

NIST BLCC: COMPARATIVE ECONOMIC ANALYSIS: FLBM7E3.CMP

BASE CASE: FLBMOS3

ALTERNATIVE: FLBM7E3

PRINCIPAL STUDY PARAMETERS:

ANALYSIS TYPE: Federal Analysis--Energy Conservation Projects STUDY PERIOD: 20 YEARS (1991 THROUGH 2010)

PLAN/CONSTR. PERIOD: 1 YEARS (1991 THROUGH 1991)

OCCUPANCY PERIOD: 19 YEARS (1992 THROUGH 2010)

DISCOUNT RATE: $4.6 \%$ Real (exclusive of general inflation)

BASE CASE LCC FILE: FLBMOS3.LCC

ALTERNATIVE LCC FIIE: FIBM7E3.LCC

COMPARISON OF PRESENT-VALUE COSTS

INITIAL INVESTMENT ITEM(S):

CASH REQUIREMENTS AS OF OCCUPANCY

SUBTOTAL

FUTURE COST ITEMS :

ANNUAL AND NON-AN. RECURRING COSTS

ENERGY EXPENDITURES

REPLACEMENTS TO CAPITAL

SUBTOTAL

TOTAL P.V. LIFE-CYCLE COST

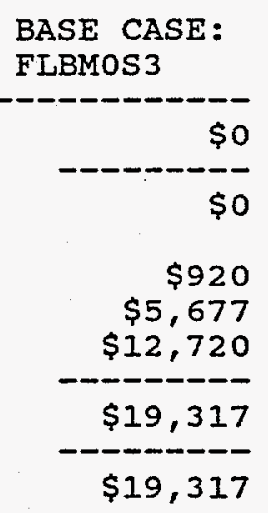

ALTERNATIVE: FLBM7E3

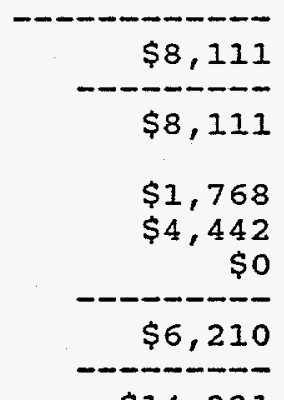

$\$ 14,321$
SAVINGS FROM ALT.

$-\$ 8,111$

$-\$ 8,111$

$-\$ 848$

$\$ 1,235$

$\$ 12,720$

$\$ 13,107$

$\$ 4,996$

NET SAVINGS FROM PROJECT FLBM7E3 COMPARED TO PROJECT FLBMOS3

Net Savings $=$ P.V. of non-investment savings

- Increased total investment $-\$ 4,609$

Net Savings:

$\$ 4,996$

SAVINGS-TO-INVESTMENT RATIO (SIR)

FOR PROJECT FLBM7E3 COMPARED TO PROJECT FLBMOS3

$$
\mathrm{SIR}=\frac{\mathrm{P} . \mathrm{V} . \text { of non-investment savings }}{\text { Increased total investment }}=-0.08
$$


FIGURE B-34.

NIST BLCC: COMPARATIVE ECONOMIC ANALYSIS: FLBN7E3.CMP

BASE CASE: FLBNOS3

ALTERNATIVE: FLBN7E3

PRINCIPAL, STUDY PARAMETERS:

ANALYSIS TYPE: Federal Analysis--Energy Conservation Projects STUDY PERIOD: 15 YEARS (1991 THROUGH 2005)

PLAN/CONSTR. PERTOD: 1 YEARS (1991 THROUGH 1991)

OCCUPANCY PERIOD: 14 YEARS (1992 THROUGH 2005)

DISCOUNT RATE: $4.6 \%$ Real (exclusive of general inflation)

BASE CASE LCC FIIE: FLBNOS3.LCC

ALTERNATIVE ICC FILE: FLBN7E3.LCC

COMPARISON OF PRESENT-VALUE COSTS

INITIAL INVESTMENT ITEM(S):

CASH REQUIREMENTS AS OF OCCUPANCY

SUBTOTAL

FUTURE COST ITEMS :

ANNUAI AND NON-AN. RECURRING COSTS

ENERGY EXPENDITURES

REPLACEMENTS TO CAPITAL

SUBTOTAI

TOTAL P.V. LIFE-CYCLE COST

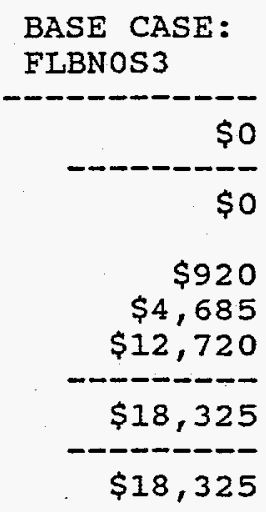

\section{ALTERNATIVE: FIBN7E3}

-

$\$ 8,111$

$\$ 8,111$

$\$ 1,768$

$\$ 3,551$

\$o

$\$ 5,320$

$\$ 13,431$
SAVINGS FROM ALT.

$-\$ 8,111$

$-\$ 8,111$

$-\$ 8,111$

$-\$ 848$

$\$ 1,133$

$\$ 12,720$

$\$ 13,005$

$\$ 4,894$

NET SAVINGS FROM PROJECT FLBN7E3 COMPARED TO PROJECT FLBNOS3

Net Savings $=$ P.V. of non-investment savings

- Increased total investment $-\$ 4,609$

Net Savings:

SAVINGS-TO-INVESTMENT RATIO (SIR)

FOR PROJECT FLBN7E3 COMPARED TO PROJECT FLBNOS3

$$
\mathrm{SIR}=\frac{\mathrm{P} \cdot \mathrm{V} \text {. of non-investment savings }}{\text { Increased total investment }}=-0.06
$$


FIGURE B-35.

NIST BLCC: COMPARATIVE ECONOMIC ANALYSIS: FLBO7E6.CMP

BASE CASE: FLBOOS6

ALTERNATIVE: FLBO7E6

PRINCIPAL STUDY PARAMETERS:

ANALYSIS TYPE: Federal Analysis--Energy conservation Projects STUDY PERIOD: 10 YEARS (1991 THROUGH 2000)

PLAN/CONSTR. PERIOD: 1 YEARS (1991 THROUGH 1991)

OCCUPANCY PERIOD: 9 YEARS ( 1992 THROUGH 2000)

DISCOUNT RATE: 4.6\% Real (exclusive of general inflation)

BASE CASE ICC FILE: FLBOOS6.LCC

ALTERNATIVE LCC FILE: FLBO7E6.LCC

COMPARISON OF PRESENT-VALUE COSTS

INITIAL INVESTMENT ITEM(S):

CASH REQUIREMENTS AS OF OCCUPANCY

SUBTOTAL

FUTURE COST ITEMS :

ANNUAL AND NON-AN. RECURRING COSTS

ENERGY EXPENDITURES

REPLACEMENTS TO CAPITAL

SUBTOTAL

TOTAL P.V. LIFE-CYCIE COST

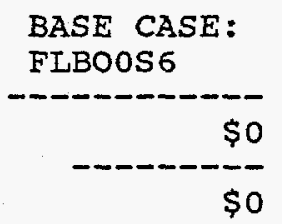

$\$ 2,375$

$\$ 6,176$

$\$ 10,152$

$\$ 18,703$

$\$ 18,703$
ALTERNATIVE : FLBO7E6

--ー-ー-ー-ー-ー

$\$ 8,111$

$\$ 8,111$

$\$ 2,203$

$\$ 4,180$

\$0

$\$ 6,384$

$\$ 14,495$
SAVINGS FROM ALT.

$-\$ 8,111$

$-\$ 8,111$

$\$ 172$

$\$ 1,995$

$\$ 10,152$

$\$ 12,319$

$\$ 4,208$

NET SAVINGS FROM PROJECT FLBO7E6 COMPARED TO PROJECT FLBOOS6

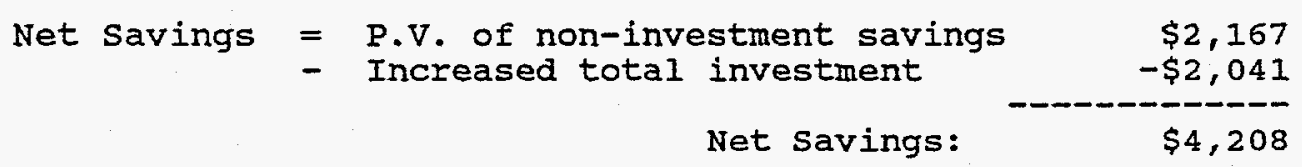

SAVINGS-TO-INVESTMENT RATIO (SIR)

FOR PROJECT FLBO7E6 COMPARED TO PROJECT FLBOOS6

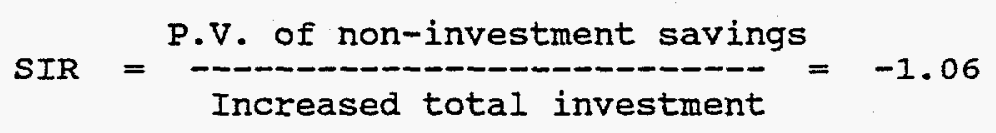


FIGURE B-36.

NIST BLCC: COMPARATIVE ECONOMIC ANALYSIS: FLBQ7E3.CMP

BASE CASE: FLBQOS3

ALTERNATIVE: FLBQ7E3

PRINCIPAL STUDY PARAMETERS:

ANALYSIS TYPE: Federal Analysis--Energy Conservation Projects STUDY PERIOD: 7 YEARS (1991 THROUGH 1997)

PIAN/CONSTR. PERIOD: 1 YEARS (1991 THROUGH 1991)

OCCUPANCY PERIOD: 6 YEARS (1992 THROUGH 1997)

DISCOUNT RATE: $4.6 \%$ Real (exclusive of general inflation)

BASE CASE LCC FILE: FLBQOS3. ICC

ALTERNATIVE LCC FILE: FLBQ7E3.LCC

COMPARISON OF PRESENT-VALUE COSTS

INITIAL INVESTMENT ITEM(S) :

CASH REQUIREMENTS AS OF OCCUPANCY

SUBTOTAL

FUTURE COST ITEMS:

ENERGY EXPENDITURES

REPLACEMENTS TO CAPITAL

SUBTOTAL

TOTAL P.V. LIFE-CYCLE COST

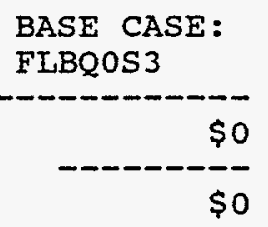

BASE CASE : FLBQOS3

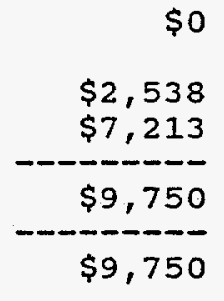

ALTERNATIVE: FLBQ7E3

$\$ 8,111$

$\$ 8,111$

$\$ 1,766$

$\$ 0$

$\$ 1,766$

$\$ 9,876$
SAVINGS

FROM ALT.

$-\$ 8,111$

$-\$ 8,111$

$\$ 772$

$\$ 7,213$

$\$ 7,985$

$-\$ 126$

SAVINGS-TO-INVESTMENT RATIO (SIR)

FOR PROJECT FLBQ7E3 COMPARED TO PROJECT FLBQOS3

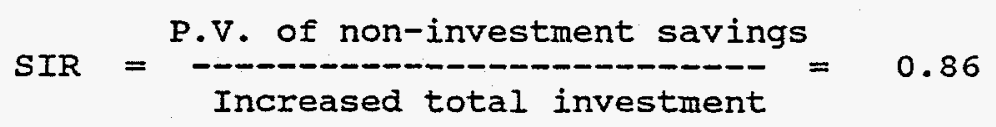


FIGURE B-37.

NIST BLCC: COMPARATIVE ECONOMIC ANALYSIS: FLBP7E3.CMP

BASE CASE: FLBPOS3

ALTERNATIVE: FLBP7E3

PRINCIPAL STUDY PARAMETERS:

ANALYSIS TYPE: Federal Analysis--Energy Conservation Projects STUDY PERIOD: 5 YEARS (1991 THROUGH 1995)

PLAN/CONSTR. PERIOD: 1 YEARS (1991 THROUGH 1991)

OCCUPANCY PERIOD: 4 YEARS (1992 THROUGH 1995)

DISCOUNT RATE: $4.6 \%$ Real (exclusive of general inflation)

BASE CASE LCC FILE: FLBPOS3.LCC

ALTERNATIVE LCC FILE: FLBP7E3.LCC

COMPARISON OF PRESENT-VALUE COSTS

INITIAL INVESTMENT ITEM(S):

CASH REQUIREMENTS AS OF OCCUPANCY

SUBTOTAL

FUTURE COST ITEMS:

ENERGY EXPENDITURES

REPLACEMENTS TO CAPITAL

SUBTOTAL

TOTAI P.V. LIFE-CYCLE COST

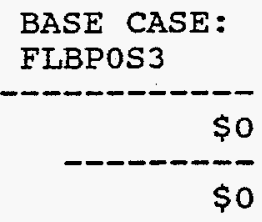

BASE CASE:

$\$ 1,942$

$\$ 3,849$

$\$ 5,792$

$-0----$

$\$ 5,792$
ALTERNATIVE: FLBP7E3

$\$ 8,111$

$\$ 8,111$

$\$ 1,316$

$\$ 0$

$\$ 1,316$

$-------$

$\$ 9,427$
SAVINGS FROM ALT.

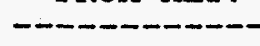

$$
-\$ 8,111
$$$$
-\$ 8,111
$$

$\$ 626$

$\$ 3,849$

$\$ 4,475$

$-\$ 3,635$

NET SAVINGS FROM PROJECT FLBP7E3 COMPARED TO PROJECT FLBPOS3

Net Savings $=$ P.V. of non-investment savings

- Increased total investment

Net Savings:

SAVINGS-TO-INVESTMENT RATIO (SIR)

FOR PROJECT FLBP7E3 COMPARED TO PROJECT FLBPOS3

$$
\mathrm{SIR}=\frac{\mathrm{P} . \mathrm{V} \cdot \text { of non-investment savings }}{\text { Increased total investment }}=0.15
$$


FIGURE B-38.

NIST BLCC: COMPARATIVE ECONOMIC ANALYSIS: FLBL7E4.CMP

BASE CASE: FLBLOS4

ALTERNATIVE: FLBL7E4

PRINCIPAL STUDY PARAMETERS:

ANALYSIS TYPE: Federal Analysis--Energy Conservation Projects STUDY PERIOD: 25 YEARS (1991 THROUGH 2015)

PLAN/CONSTR. PERIOD: 1 YEARS (1991 THROUGH 1991)

OCCUPANCY PERIOD: 24 YEARS (1992 THROUGH 2015)

DISCOUNT RATE: $4.6 \%$ Real (exclusive of general inflation)

BASE CASE LCC FILE: FLBLOS4.LCC

ALTERNATIVE LCC FILE: FLBL7E4.LCC

COMPARISON OF PRESENT-VALUE COSTS

INITIAL INVESTMENT ITEM(S):

CASH REQUIREMENTS AS OF OCCUPANCY SUBTOTAL

FUTURE COST ITEMS:

ANNUAL AND NON-AN. RECURRING COSTS

ENERGY EXPENDITURES

REPLACEMENTS TO CAPITAL

SUBTOTAL

TOTAL P.V. LIFE-CYCLE COST

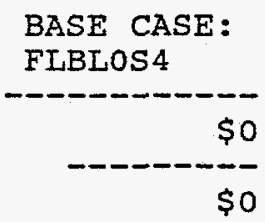

$$
\begin{array}{r}
\$ 2,396 \\
\$ 8,183 \\
\$ 12,720 \\
\hdashline \$ 23,299 \\
\hline \$ 23,299
\end{array}
$$

ALTERNATIVE: FLBL7E4 - -

$\$ 8,111$

$\$ 8,111$

$\$ 3,090$

$\$ 6,340$

$-\frac{\$ 0}{\$ 9,430}$

$\$ 17,541$
SAVINGS

FROM ALT.

$-\cdots-c-1$

$-\$ 8,111$

$-\$ 8,111$

$-\$ 694$

$\$ 1,843$

$\$ 12,720$

$\$ 13,869$

$\$ 5,758$

NET SAVINGS FROM PROJECT FLBL7E4 COMPARED TO PROJECT FLBLOS4

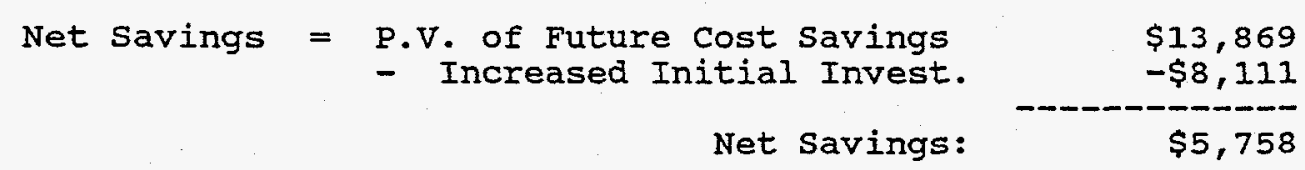

SAVINGS-TO-INVESTMENT RATIO (SIR)

FOR PROJECT FLBL7E4 COMPARED TO PROJECT FLBLOS4

$$
\text { SIR }=\frac{\text { P.V. of Future cost Savings }}{\text { Increased Initial Invest. }}=1.71
$$


FIGURE B-39.

NIST BLCC: COMPARATIVE ECONOMIC ANALYSIS: FLBM7E4.CMP

BASE CASE: FLBMOS4

ALTERNATIVE: FLBM7E4

PRINCIPAL STUDY PARAMETERS:

ANALYSIS TYPE: Federal Analysis--Energy conservation Projects STUDY PERIOD: 20 YEARS (1991 THROUGH 2010)

PLAN/CONSTR. PERIOD: 1 YEARS (1991 THROUGH 1991)

OCCUPANCY PERIOD: 19 YEARS (1992 THROUGH 2010)

DISCOUNT RATE: 4.6\% Real (exclusive of general inflation)

BASE CASE LCC FILE: FLBMOS4.LCC

ALTERNATIVE LCC FILE: FLBM7E4. LCC

COMPARISON OF PRESENT-VALUE COSTS

INITIAL INVESTMENT ITEM(S):

CASH REQUIREMENTS AS OF OCCUPANCY

SUBTOTAL

FUTURE COST ITEMS:

ANNUAL AND NON-AN. RECURRING COSTS

ENERGY EXPENDITURES

REPLACEMENTS TO CAPITAL

SUBTOTAL

TOTAL P.V. IIFE-CYCLE COST

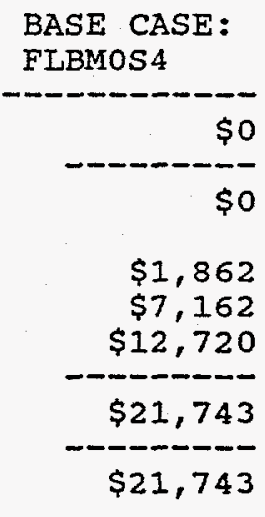

AITERNATIVE: FIBM7E4

$\$ 8,111$

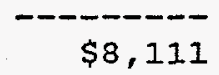

$\$ 2,556$

$\$ 5,449$

$\$ 0$

$\$ 8,005$

$\$ 16,116$
SAVINGS FROM ALT.

- - - - - -

$$
-\$ 8,111
$$$$
-\$ 8,111
$$

$-\$ 694$

$\$ 1,713$

$\$ 12,720$

$\$ 13,739$

$\$ 5,628$

NET SAVINGS FROM PROJECT FLBM7E4 COMPARED TO PROJECT FLBMOS4

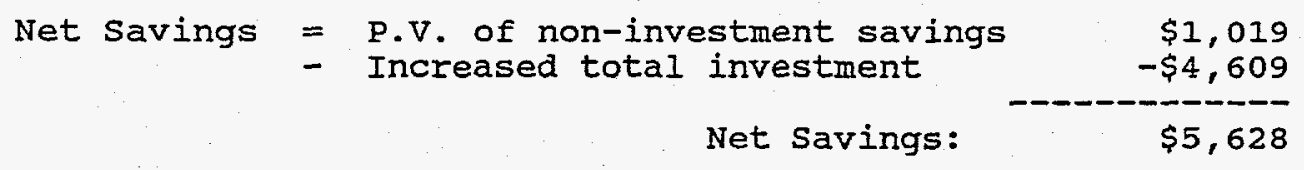

SAVINGS-TO-INVESTMENT RATIO (SIR)

FOR PROJECT FLBM7E4 COMPARED TO PROJECT FLBMOS 4

$$
\mathrm{SIR}=\frac{\mathrm{P} . \mathrm{V} . \text { of non-investment savings }}{\text { Increased total investment }}=-0.22
$$


FIGURE B-40.

NIST BLCC: COMPARATIVE ECONOMIC ANALYSIS: FLBN7E4.CMP

BASE CASE: FLBNOS4

ALTERNATIVE: FLBN7E4

PRINCIPAL STUDY PARAMETERS:

ANALYSIS TYPE: Federal Analysis--Energy Conservation Projects STUDY PERIOD: 15 YEARS (1991 THROUGH 2005)

PLAN/CONSTR. PERIOD: 1 YEARS (1991 THROUGH 1991)

OCCUPANCY PERIOD: 14 YEARS (1992 THROUGH 2005)

DISCOUNT RATE: $4.6 \%$ Real (exclusive of general inflation)

BASE CASE LCC FILE: FLBNOS4.LCC

ALTERNATIVE LCC FILE: FLBN7E4.LCC

COMPARISON OF PRESENT-VALUE COSTS

INITIAL INVESTMENT ITEM(S):

CASH REQUIREMENTS AS OF OCCUPANCY

SUBTOTAL

FUTURE COST ITEMS:

ANNUAL AND NON-AN. RECURRING COSTS

ENERGY EXPENDITURES

REPLACEMENTS TO CAPITAL

SUBTOTAL

TOTAL P.V. LIFE-CYCLE COST

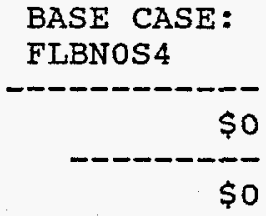

$$
\begin{array}{r}
\$ 1,226 \\
\$ 5,911 \\
\$ 12,720 \\
\hline \$ 19,857 \\
\hline \$ 19,857
\end{array}
$$

ALTERNATIVE: FLBN7E4

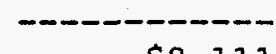

$\$ 8,111$

$\$ 8,111$

$\$ 1,887$

$\$ 4,357$

\$0

$\$ 6,244$

$\$ 14,355$
SAVINGS

FROM ALT.

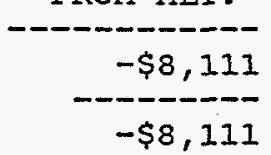

$-\$ 660$

$\$ 1,553$

$\$ 12,720$

$\$ 13,613$

$\$ 5,502$

NET SAVINGS FROM PROJECT FLBN7E4 COMPARED TO PROJECT FLBNOS4

$\begin{array}{rrr}\text { Net savings }=\text { P.V. of non-investment savings } & \$ 893 \\ & - \text { Increased total investment } & -\$ 4,609 \\ & \text { Net Savings: } & \$ 5,502\end{array}$

SAVINGS-TO-INVESTMENT RATIO (SIR)

FOR PROJECT FLBN7E4 COMPARED TO PROJECT FLBNOS4

$$
\mathrm{SIR}=\frac{\mathrm{P} . \mathrm{V} . \text { of non-investment savings }}{\text { Increased total investment }}=-0.19
$$


FIGURE B-41.

NIST BLCC: COMPARATIVE ECONOMIC ANALYSIS: FLBO7E4.CMP

BASE CASE: FLBOOS 4

ALTERNATIVE: FLBO7E4

PRINCIPAL STUDY PARAMETERS:

ANALYSIS TYPE: FederaI Analysis--Energy conservation Projects STUDY PERIOD: 10 YEARS (1991 THROUGH 2000)

PIAN/CONSTR. PERIOD: 1 YEARS (1991 THROUGH 1991)

OCCUPANCY PERIOD: 9 YEARS (1992 THROUGH 2000)

DISCOUNT RATE: 4.6\% Real (exclusive of general inflation)

BASE CASE LCC FILE: FLBOOS4.LCC

ALTERNATIVE ICC FILE: FLBOTE4.LCC

COMPARISON OF PRESENT-VALUE COSTS

\begin{tabular}{|c|c|c|c|}
\hline & $\begin{array}{l}\text { BASE CASE: } \\
\text { FLBOOS } 4\end{array}$ & $\begin{array}{l}\text { ALTERNATIVE: } \\
\text { FLBO7E4 }\end{array}$ & $\begin{array}{l}\text { SAVINGS } \\
\text { FROM ALT. }\end{array}$ \\
\hline $\begin{array}{l}\text { INITIAL INVESTMENT ITEM(S): } \\
\text { CASH REQUIREMENTS AS OF OCCUPANCY }\end{array}$ & $\$ 0$ & $\$ 8,111$ & $-\$ 8,111$ \\
\hline SUBTOTAL & \$o & $\$ 8,111$ & $-\$ 8,111$ \\
\hline $\begin{array}{l}\text { FUTURE COST ITEMS: } \\
\text { ANNUAL AND NON-AN. RECURRING COSTS } \\
\text { ENERGY EXPENDITURES } \\
\text { REPLACEMENTS TO CAPITAL }\end{array}$ & $\begin{array}{r}\$ 682 \\
\$ 4,365 \\
\$ 10,152\end{array}$ & $\begin{array}{r}\$ 1,049 \\
\$ 3,052 \\
\$ 0\end{array}$ & $\begin{array}{r}-\$ 367 \\
\$ 1,314 \\
\$ 10,152\end{array}$ \\
\hline SÜBTOTAL & $\$ 15,199$ & $\$ 4,101$ & $\$ 11,098$ \\
\hline TOTAL P.V. LIFE-CYCLE COST & $\$ 15,199$ & $\$ 12,211$ & $\$ 2,987$ \\
\hline
\end{tabular}

NET SAVINGS FROM PROJECT FLBO7E4 COMPARED TO PROJECT FLBOOS 4

Net Savings $=$ P.V. of non-investment savings $\$ 946$

- Increased total investment $-\$ 2,041$

Net Savings: $\quad \$ 2,987$

SAVINGS-TO-INVESTMENT RATIO (SIR)

FOR PROJECT FLBO7E4 COMPARED TO PROJECT FLBOOS 4

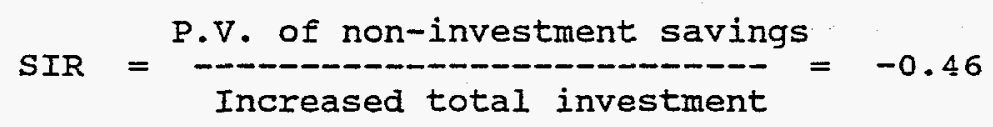


FIGURE B-42.

NIST BLCC: COMPARATIVE ECONOMIC ANALYSIS: FLBQ7E4.CMP

BASE CASE: FLBQOS4

ALTERNATIVE: FLBQ7E4

PRINCIPAL STUDY PARAMETERS:

ANALYSIS TYPE: Federal Analysis--Energy Conservation Projects STUDY PERIOD: 7 YEARS (1991 THROUGH 1997)

PLAN/CONSTR. PERIOD: 1 YEARS (1991 THROUGH 1991)

OCCUPANCY PERIOD: 6 YEARS (1992 THROUGH 1997)

DISCOUNT RATE: $4.6 \%$ Real (exclusive of general inflation)

BASE CASE LCC FILE: FLBQOS4.LCC

ALTERNATIVE LCC FILE: FLBQ7E4.LCC

COMPARISON OF PRESENT-VALUE COSTS

\begin{tabular}{|c|c|c|c|}
\hline & $\begin{array}{l}\text { BASE CASE: } \\
\text { FLBQOS } 4\end{array}$ & $\begin{array}{l}\text { ALTERNATIVE: } \\
\text { FLBQ7E4 }\end{array}$ & $\begin{array}{l}\text { SAVINGS } \\
\text { FROM ALT. }\end{array}$ \\
\hline INITIAL INVESTMENT ITEM(S): & -ーーーーーーーーーーー & 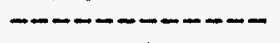 & 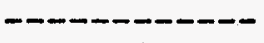 \\
\hline CASH REQUIREMENTS AS OF OCCUPANCY & $\$ 0$ & $\$ 8,111$ & $-\$ 8,111$ \\
\hline SUBTOTAL & $\$ 0$ & $\$ 8,111$ & $-\$ 8,111$ \\
\hline FUTURE COST ITEMS: & & & \\
\hline ANNUAI AND NON-AN. RECURRING COSTS & $\$ 682$ & $\$ 1,049$ & $-\$ 367$ \\
\hline ENERGY EXPENDITURES & $\$ 3,467$ & $\$ 2,326$ & $\$ 1,141$ \\
\hline REPLACEMENTS TO CAPITAL & $\$ 7,213$ & \$o & $\$ 7,213$ \\
\hline SUBTOTAL & $\$ 11,362$ & $\$ 3,375$ & $\$ 7,987$ \\
\hline TOTAL P.V. LIFE-CYCLE COST & $\$ 11,362$ & $\$ 11,486$ & $-\$ 124$ \\
\hline
\end{tabular}

NET SAVINGS FROM PROJECT FLBQ7E4 COMPARED TO PROJECT FLBQOS4

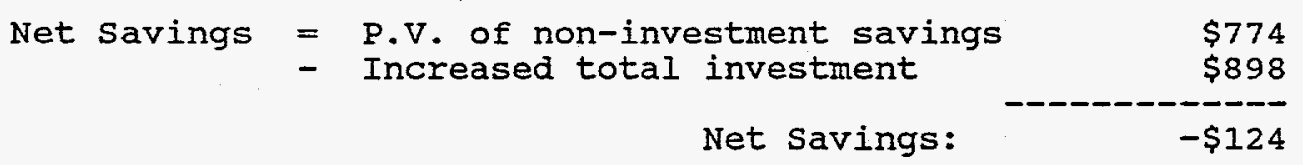

SAVINGS-TO-INVESTMENT RATIO (SIR)

FOR PROJECT FLBQ7E4 COMPARED TO PROJECT FLBQOS4

$$
\text { SIR }=\frac{\text { P.V. of non-investment savings }}{\text { Increased total investment }}=0.86
$$


FIGURE B-43.

NIST BLCC: COMPARATIVE ECONOMIC ANALYSIS: FLBP7E4.CMP

BASE CASE: FLBPOS4

ALTERNATIVE: FLBP7E4

PRINCIPAL STUDY PARAMETERS:

ANALYSIS TYPE: Federal Analysis--Energy Conservation Projects STUDY PERIOD: 5 YEARS (1991 THROUGH 1995)

PLAN/CONSTR. PERIOD: I YEARS (1991 THROUGH 1991)

OCCUPANCY PERIOD: 4 YEARS (1992 THROUGH 1995)

DISCOUNT RATE: $4.6 \%$ Real (exclusive of general inflation)

BASE CASE LCC FILE: FLBPOS4.LCC

ALTERNATIVE LCC FIIE: FLBP7E4.ICC

COMPARISON OF PRESENT-VALUE COSTS

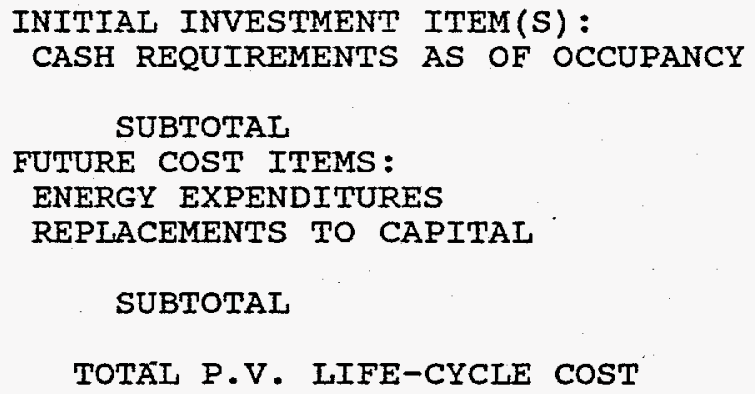

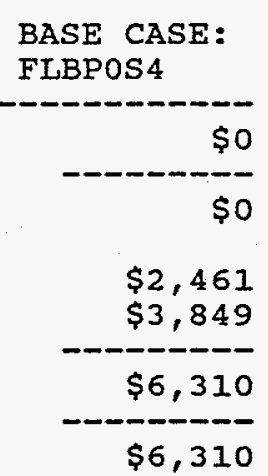

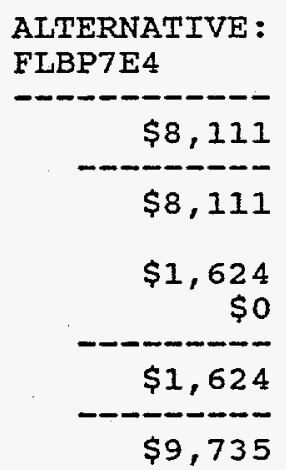

SAVINGS FROM AIT.

$---10-1$

$-\$ \$ 8,111$

$-\$ 8,111$

$\$ 837$

$\$ 3,849$

$\$ 4,686$

$-\$ 3,425$

\begin{abstract}
NET SAVINGS FROM PROJECT FLBP7E4 COMPARED TO PROJECT FLBPOS4
\end{abstract}
SAVINGS-TO-INVESTMENT RATIO (SIR)

FOR PROJECT FLBP7E4 COMPARED TO PROJECT FLBPOS4

$$
\text { SIR }=\frac{\text { P.V. of non-investment savings }}{\text { Increased total investment }}=0.20
$$


FIGURE B-44.

NIST BLCC: COMPARATIVE ECONOMIC ANALYSIS: FLBL7E6.CMP

BASE CASE: FLBLOS6

ALTERNATIVE: FLBL7E6

PRINCIPAL STUDY PARAMETERS:

ANALYSIS TYPE: Federal Analysis--Energy Conservation Projects STUDY PERIOD: 25 YEARS (1991 THROUGH 2015)

PLAN/CONSTR. PERIOD: 1 YEARS (1991 THROUGH 1991)

OCCUPANCY PERIOD: 24 YEARS (1992 THROUGH 2015)

DISCOUNT RATE: 4.6\% Real (exclusive of general inflation)

BASE CASE ICC FIIE: FLBLOS6.LCC

ALTERNATIVE LCC FILE: FLBL7E6.LCC

COMPARISON OF PRESENT-VALUE COSTS

\begin{tabular}{|c|c|c|c|}
\hline & $\begin{array}{l}\text { BASE CASE: } \\
\text { FLBLOS6 }\end{array}$ & $\begin{array}{l}\text { ALTERNATIVE: } \\
\text { FLBL7E6 }\end{array}$ & $\begin{array}{l}\text { SAVINGS } \\
\text { FROM ALT. }\end{array}$ \\
\hline $\begin{array}{l}\text { INITIAL INVESTMENT ITEM(S): } \\
\text { CASH REQUIREMENTS AS OF OCCUPANCY }\end{array}$ & $\$ 0$ & $\$ 8,111$ & $-\$ 8,111$ \\
\hline $\begin{array}{l}\text { SUBTOTAI, } \\
\text { FUTURE COST ITEMS: }\end{array}$ & \$0 & $\$ 8,111$ & $-\$ 8,111$ \\
\hline $\begin{array}{l}\text { ANNUAL AND NON-AN. RECURRING COSTS } \\
\text { ENERGY EXPENDITURES } \\
\text { REPLACEMENTS TO CAPITAL }\end{array}$ & $\begin{array}{r}\$ 5,842 \\
\$ 11,578 \\
\$ 12,720\end{array}$ & $\begin{array}{l}\$ 4,892 \\
\$ 8,686 \\
\$ 3,776\end{array}$ & $\begin{array}{r}\$ 950 \\
\$ 2,892 \\
\$ 8,944\end{array}$ \\
\hline SÜBTOTAL & $\$ 30,139$ & $\$ 17,354$ & $\$ 12,785$ \\
\hline TOTAL P.V. LIFE-CYCIE COST & $\$ 30,139$ & $\$ 25,465$ & $\$ 4,674$ \\
\hline
\end{tabular}

NET SAVINGS FROM PROJECT FLBI7E6 COMPARED TO PROJECT FLBLOS6

$\begin{array}{rrrr}\text { Net Savings } & =\text { P.V. of non-investment savings } & \$ 3,842 \\ & - & \text { Increased total investment } & -\$ 833 \\ & & \text { Net Savings: } & \$ 4,674\end{array}$

SAVINGS-TO-INVESTMENT RATIO (SIR)

FOR PROJECT FLBL7E6 COMPARED TO PROJECT FLBLOS6

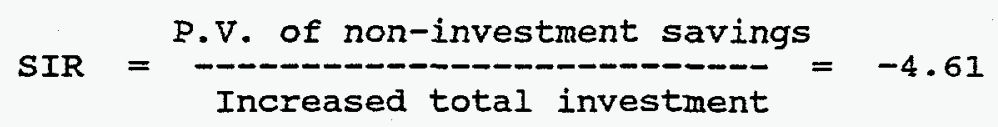


FIGURE B-45.

NIST BLCC: COMPARATIVE ECONOMIC ANALYSIS: FLBM7E6.CMP

BASE CASE: FLBMOS6

AITERNATIVE: FIBM7E6

PRINCIPAI STUDY PARAMETERS:

ANALYSIS TYPE: Federal Analysis--Energy conservation Projects STUDY PERIOD: 20 YEARS (1991 THROUGH 2010)

PLAN/CONSTR. PERIOD: 1 YEARS (1991 THROUGH 1991)

OCCUPANCY PERIOD: 19 YEARS (1992 THROUGH 2010)

DISCOUNT RATE: $4.6 \%$ Real (exclusive of general inflation)

BASE CASE LCC FILE: FLBMOS6.LCC

ALTERNATIVE LCC FILE: FLBM7E6. LCC

COMPARISON OF PRESENT-VALUE COSTS

INITIAL INVESTMENT ITEM(S):

CASH REQUIREMENTS AS OF OCCUPANCY

SUBTOTAL

FUTURE COST ITEMS:

ANNUAL AND NON-AN. RECURRING COSTS

ENERGY EXPENDITURES

REPIACEMENTS TO CAPITAL

SUBTOTAL

TOTAL P.V. IIFE-CYCLE COST

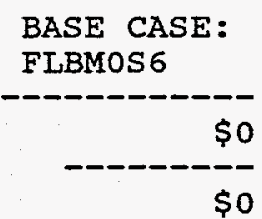

$\begin{array}{r}\$ 4,749 \\ \$ 10,133 \\ \$ 12,720 \\ \hline \$ 27,601 \\ \hline \$ 27,601\end{array}$

$\$ 10,133$

$\$ 27,601$

ALTERNATIVE : FLBM7E6

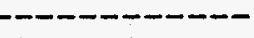

$\$ 8,111$

$\$ 8,111$

$\$ 3,845$

$\$ 7,465$

$\$ 3,776$

$\$ 15,086$

$\$ 23,197$

SAVINGS

FROM ALT.

$-\$ 8,111$

$-\$ 8,111$

$\$ 904$

$\$ 2,668$

$\$ 8,944$

$\$ 12,515$

$\$ 4,404$

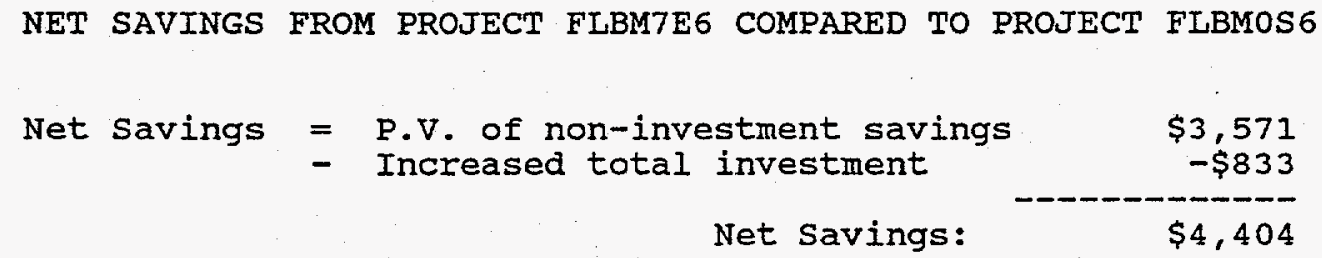

SAVINGS-TO-INVESTMENT RATIO (SIR)

FOR PROJECT FIBM7E6 COMPARED TO PROJECT FLBMOS6

$$
S I R=\frac{\text { P.V. of non-investment savings }}{\text { Increased total investment }}=-4.29
$$


FIGURE B-46.

NIST BLCC: COMPARATIVE ECONOMIC ANALYSIS: FLBN7E6.CMP

BASE CASE: FLBNOS6

ALTERNATIVE: FLBN7E6

PRINCIPAL STUDY PARAMETERS:

ANALYSIS TYPE: Federal Analysis--Energy Conservation Projects STUDY PERIOD: 15 YEARS (1991 THROUGH 2005)

PLAN/CONSTR. PERIOD: 1 YEARS (1991 THROUGH 1991)

OCCUPANCY PERIOD: 14 YEARS (1992 THROUGH 2005)

DISCOUNT RATE: $4.6 \%$ Real (exclusive of general inflation)

BASE CASE LCC FILE: FLBNOS6. LCC

ALTERNATIVE LCC FILE: FLBN7E6. LCC

COMPARISON OF PRESENT-VALUE COSTS

INITIAL INVESTMENT ITEM(S):

CASH REQUIREMENTS AS OF OCCUPANCY

SUBTOTAL

FUTURE COST ITEMS:

ANNUAL AND NON-AN. RECURRING COSTS

ENERGY EXPENDITURES

REPLACEMENTS TO CAPITAL

SUBTOTAL

TOTAL P.V. LIFE-CYCLE COST

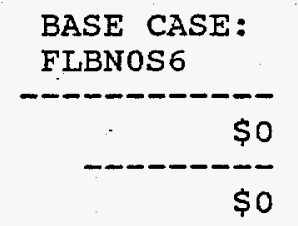

BASE CASE:

$\begin{array}{r}\$ 2,976 \\ \$ 8,362 \\ \$ 12,720 \\ \hline \$ 24,058 \\ \hline \$ 24,058\end{array}$

ALTERNATIVE: FLBN7E6

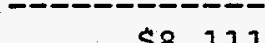

$$
\begin{array}{r}
\$ 8,111 \\
\$ 3,845 \\
\$ 5,969 \\
\$ 0 \\
\hline \$ 9,814 \\
\hline \$ 17,925
\end{array}
$$

SAVINGS FROM ALT.

-

$$
-\$ 8,111
$$$$
-\$ 8,111
$$

$-\$ 869$

$\$ 2,393$

$\$ 12,720$

$\$ 14,244$

$\$ 6,133$

NET SAVINGS FROM PROJECT FLBN7E6 COMPARED TO PROJECT FLBNOS6

$\begin{array}{rlr}\text { Net Savings }= & \text { P.V. of non-investment savings } & \$ 1,524 \\ & - \text { Increased total investment } & -\$ 4,609 \\ & \text { Net Savings: } & \$ 6,133\end{array}$

SAVINGS-TO-INVESTMENT RATIO (SIR)

FOR PROJECT FLBN7E6 COMPARED TO PROJECT FLBNOS6

$$
S I R=\frac{P . V . \text { of non-investment savings }}{\text { Increased total investment }}=-0.33
$$


FIGURE B-47.

NIST BLCC: COMPARATIVE ECONOMIC ANALYSIS: FLBO7E3.CMP

BASE CASE: FLBOOS3

ALTERNATIVE: FLBO7E3

PRINCIPAL STUDY PARAMETERS:

ANALYSIS TYPE: Federal Analysis--Energy Conservation Projects STUDY PERIOD: 10 YEARS (1991 THROUGH 2000)

PLAN/CONSTR. PERIOD: 1 YEARS (1991 THROUGH 1991)

OCCUPANCY PERIOD: 9 YEARS (1992 THROUGH 2000)

DISCOUNT RATE: $4.6 \%$ Real (exclusive of general inflation)

BASE CASE LCC FILE: FLBO0S3. ICC

ALTERNATIVE LCC FILE: FLBO7E3. ICC

COMPARISON OF PRESENT-VALUE COSTS

\begin{tabular}{|c|c|c|c|}
\hline 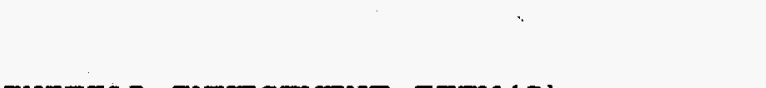 & $\begin{array}{l}\text { BASE CASE: } \\
\text { FLBOOS3 }\end{array}$ & $\begin{array}{l}\text { ALTERNATIVE: } \\
\text { FLBO7E3 }\end{array}$ & $\begin{array}{l}\text { SAVINGS } \\
\text { FROM ALT. }\end{array}$ \\
\hline $\begin{array}{l}\text { INITIAL INVESTMENT ITEM(S): } \\
\text { CASH REQUIREMENTS AS OF OCCUPANCY }\end{array}$ & \$0 & $\$ 8,111$ & $-\$ 8,111$ \\
\hline $\begin{array}{l}\text { SUBTOTAL } \\
\text { FUTURE COST ITEMS: }\end{array}$ & \$0 & $\$ 8,111$ & $-\$ 8,1$ \\
\hline $\begin{array}{l}\text { ANNUAL AND NON-AN. RECURRING COSTS } \\
\text { ENERGY EXPENDITURES } \\
\text { REPLACEMENTS TO CAPITAL }\end{array}$ & $\begin{array}{r}\$ 502 \\
\$ 3,695 \\
\$ 10,152\end{array}$ & $\begin{array}{r}\$ 1,003 \\
\$ 2,487 \\
\$ 0\end{array}$ & $\begin{array}{r}-\$ 501 \\
\$ 1,208 \\
\$ 10,152\end{array}$ \\
\hline SUBTOTAL & $\$ 14,349$ & $\$ 3,490$ & $\$ 10,859$ \\
\hline TOTAL P.V. LIFE & $\$ 14,349$ & $\$ 11,601$ & $\$ 2,748$ \\
\hline
\end{tabular}

NET SAVINGS FROM PROJECT FLBO7E3 COMPARED TO PROJECT FLBOOS3

Net Savings $=$ P.V. of non-investment savings $\$ 707$

- Increased total investment $\quad-\$ 2,041$

Net Savings: $\quad \$ 2,748$

SAVINGS-TO-INVESTMENT RATIO (SIR)

FOR PROJECT FLBOTE3 COMPARED TO PROJECT FLBOOS 3

$$
\text { SIR }=\frac{\text { P.V. of non-investment savings }}{\text { Increased total investment }}=-0.35
$$


FIGURE B-48.

NIST BLCC: COMPARATIVE ECONOMIC ANALYSIS: FLBQ7E6.CMP

BASE CASE: FLBQOS6

ALTERNATIVE: FLBQ7E6

PRINCIPAL STUDY PARAMETERS:

ANALYSIS TYPE: Federal Analysis--Energy Conservation Projects STUDY PERIOD: 7 YEARS (1991 THROUGH 1997)

PLAN/CONSTR. PERIOD: 1 YEARS (1991 THROUGH 1991)

OCCUPANCY PERIOD: 6 YEARS ( 1992 THROUGH 1997)

DISCOUNT RATE: 4.6\% Real (exclusive of general inflation)

BASE CASE LCC FIIE: FLBQOS6.LCC

ALTERNATIVE LCC FILE: FLBQ7E6.LCC

COMPARISON OF PRESENT-VALUE COSTS

INITIAL INVESTMENT ITEM(S):

CASH REQUIREMENTS AS OF OCCUPANCY

SUBTOTAL

FUTURE COST ITEMS :

ANNUAI AND NON-AN. RECURRING COSTS

ENERGY EXPENDITURES

REPLACEMENTS TO CAPITAL

SUBTOTAL

TOTAL P.V. LIFE-CYCLE COST
BASE CASE:

FLBQOS6
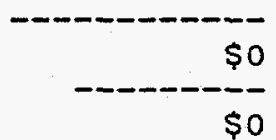

$\$ 1,687$

$\$ 4,682$

$\$ 7,213$

$--\cdots----1$

$\$ 13,583$

$\$ 13,583$
AITERNATIVE : FLBQ7E6

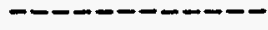
$\$ 8,111$
$\$ 8,111$

$\$ 1,200$

$\$ 2,912$

$\$ 0$

$\$ 4,113$

$\$ 12,224$
SAVINGS FROM ALT.

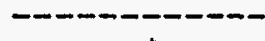

$-\$ 8,111$

$-\$ 8,111$

$\$ 487$

$\$ 1,770$

$\$ 7,213$

$\$ 9,470$

$\$ 1,359$

NET SAVINGS FROM PROJECT FLBQ7E6 COMPARED TO PROJECT FLBQOS6

$\begin{array}{rrr}\text { Net Savings }=\text { P.v. of non-investment savings } & \$ 2,257 \\ & - \text { Increased total investment } & \$ 898 \\ & \text { Net Savings: } & \$ 1,359\end{array}$

SAVINGS-TO-INVESTMENT RATIO (SIR)

FOR PROJECT FLBQ7E6 COMPARED TO PROJECT FLBQOS6

P.V. of non-investment savings

$\mathrm{SIR}=\frac{\mathrm{Increased} \text { total investment }}{\text { Incis }}=2.51$ 
FIGURE B-49.

NIST BLCC: COMPARATIVE ECONOMIC ANALYSIS: FLBP7E6.CMP

BASE CASE: FLBPOS6

ALTERNATIVE: FLBP7E6

PRINCIPAI STUDY PARAMETERS:

ANALYSIS TYPE: Federal Analysis--Energy Conservation Projects STUDY PERIOD: 5 YEARS (1991 THROUGH 1995)

PIAN/CONSTR. PERIOD: 1 YEARS (1991 THROUGH 1991)

OCCUPANCY PERIOD: 4 YEARS (1992 THROUGH 1995)

DISCOUNT RATE: $4.6 \%$ Real (exclusive of general inflation)

BASE CASE I,CC FILE: FLBPOS6.LCC

ALTERNATIVE LCC FILE: FLBP7E6.LCC

COMPARISON OF PRESENT-VALUE COSTS

INITIAL INVESTMENT ITEM(S):

CASH REQUIREMENTS AS OF OCCUPANCY

SUBTOTAL

FUTURE COST ITEMS :

ANNUAI AND NON-AN. RECURRING COSTS

ENERGY EXPENDITURES

REPLACEMENTS TO CAPITAL

SUBTOTAL

TOTAL P.V. IIFE-CYCIE COST

\section{BASE CASE: FLBP0S6}

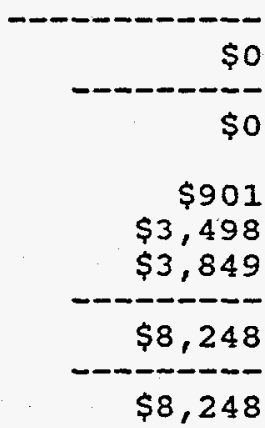

$\$ 0$

$\$ 0$
ALTERNATIVE: FLBP7E6

$-\cdots------$

$\$ 8,111$

$\$ 8,111$

$\$ 1,200$

$\$ 2,239$

$\$ 0$

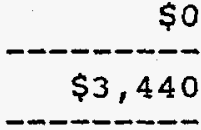

$\$ 11,551$
SAVINGS

FROM ALT.

- - - - - -

$-\$ 8,111$

$-\$ 8,111$

$-\$ 300$

$\$ 1,258$

$\$ 3,849$

$\$ 4,808$

$-\$ 3,303$

NET SAVINGS FROM PROJECT FLBP7E6 COMPARED TO PROJECT FLBPOS6

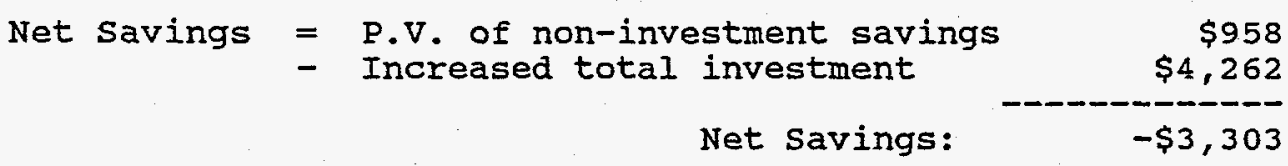

SAVINGS-TO-INVESTMENT RATIO (SIR)

FOR PROJECT FLBP7E6 COMPARED TO PROJECT FLBPOS6

$$
\text { SIR }=\frac{\text { P.V. of non-investment savings }}{\text { Increased total investment }}=0.22
$$


FIGURE B-50.

NIST BLCC: COMPARATIVE ECONOMIC ANALYSIS: FLFLTE4.CMP

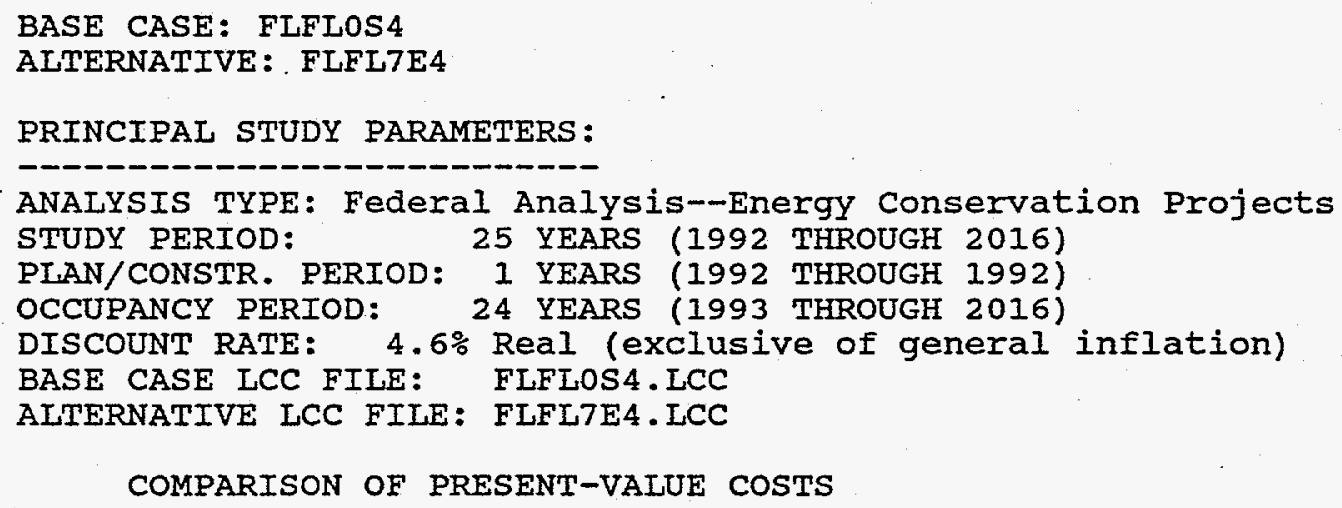

INITIAL INVESTMENT ITEM(S):

CASH REQUIREMENTS AS OF OCCUPANCY

SUBTOTAL

FUTURE COST ITEMS:

ANNUAL AND NON-AN. RECURRING COSTS

ENERGY EXPENDITURES

REPLACEMENTS TO CAPITAL

SUBTOTAL

TOTAL P.V. LIFE-CYCLE COST

\section{BASE CASE:} FLFLOS4

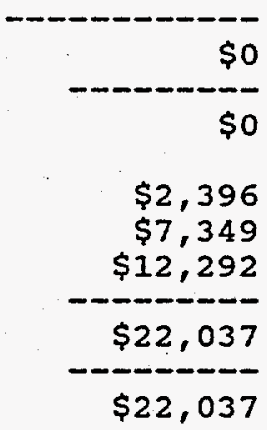

ALTERNATIVE: FLFL7E4

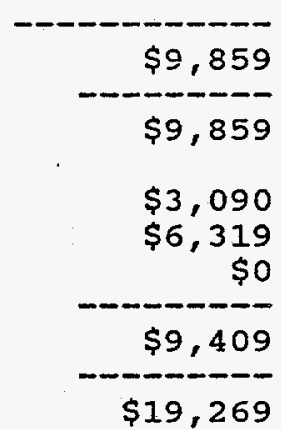

SAVINGS FROM ALT.

$$
-\$ 9,859
$$$$
-\$ 9,859
$$

$-\$ 694$

$\$ 1,029$

$\$ 12,292$

$\$ 12,627$

$\$ 2,768$

NET SAVINGS FROM PROJECT FLFL7E4 COMPARED TO PROJECT FLFLOS4

Net Savings $=$ P.V. of non-investment savings

- Increased total investment

Net Savings:

SAVINGS-TO-INVESTMENT RATIO (SIR)

FOR PROJECT FLFL7E4 COMPARED TO PROJECT FLFLOS4

$$
\mathrm{SIR}=\frac{\mathrm{P} . \mathrm{V} \cdot \text { of non-investment savings }}{\text { Increased total investment }}=-0.14
$$


FIGURE B-51.

NIST BLCC: COMPARATIVE ECONOMIC ANALYSIS: FLFM7E4.CMP

BASE CASE: FLFMOS4

ALTERNATIVE: FLFM7E4

PRINCIPAL STUDY PARAMETERS:

ANALYSIS TYPE: Federal Analysis--Energy Conservation Projects STUDY PERIOD: 20 YEARS (1992 THROUGH 2011)

PLAN/CONSTR. PERIOD: 1 YEARS (1992 THROUGH 1992)

OCCUPANCY PERIOD: 19 YEARS (1993 THROUGH 2011)

DISCOUNT RATE: $4.6 \%$ Real (exclusive of general inflation)

BASE CASE LCC FIIE: FLFMOS4.LCC

ALTERNATIVE LCC FILE: FLFM7E4.LCC

COMPARISON OF PRESENT-VALUE COSTS

INITIAL INVESTMENT ITEM(S):

CASH REQUIREMENTS AS OF OCCUPANCY

$$
\text { SUBTOTAL }
$$

FUTURE COST ITEMS:

ANNUAL AND NON-AN. RECURRING COSTS

ENERGY EXPENDITURES

REPLACEMENTS TO CAPITAL

SUBTOTAL

TOTAL P.V. LIFE-CYCLE COST

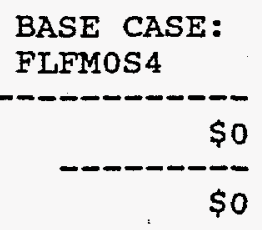

$\$ 1,862$

$\$ 6,537$

$\$ 12,292$

$\$ 20,690$

$\$ 20,690$
ALTERNATIVE : FLFM7E4

$-$

$\$ 9,859$

$\$ 9,859$

$\$ 2,556$

$\$ 5,426$

$\$ 0$

$\$ 7,981$

$\$ 17,841$
SAVINGS FROM ALT.
$-\$ 9,859$
$-\$ 9,859$

$-\$ 694$

$\$ 1,111$

$\$ 12,292$

$\$ 12,709$

$\$ 2,849$

NET SAVINGS FROM PROJECT FLFM7E4 COMPARED TO PROJECT FLFMOS4

Net Savings $=$ P.V. of non-investment savings

- Increased total investment

Net Savings:

SAVINGS-TO-INVESTMENT RATIO (SIR)

FOR PROJECT FLFM7E4 COMPARED TO PROJECT FLFMOS4

P.V. of non-investment savings

$$
S I R=\frac{P . V . \text { of non-investment savings }}{\text { Increased total investment }}=-0.17
$$


FIGURE B-52.

NIST BLCC: COMPARATIVE ECONOMIC ANALYSIS: FLFN7E4.CMP

BASE CASE: FLFNOS4

ALTERNATIVE: FLFN7E4

PRINCIPAL STUUDY PARAMETERS:

ANALYSIS TYPE: Federal Analysis--Energy conservation Projects STUDY PERIOD: 15 YEARS (1992 THROUGH 2006)

PLAN/CONSTR. PERIOD: I YEARS (1992 THROUGH 1992)

OCCUPANCY PERIOD: 14 YEARS (1993 THROUGH 2006)

DISCOUNT RATE: 4.6\% Real (exclusive of general inflation)

BASE CASE LCC FILE: FLFNOS4.LCC

ALTERNATIVE LCC FILE: FLFN7E4.LCC

COMPARISON OF PRESENT-VALUE COSTS

INITIAL INVESTMENT ITEM(S):

CASH REQUIREMENTS AS OF OCCUPANCY

SUBTOTAT

FUTURE COST ITEMS:

ANNUAL AND NON-AN. RECURRING COSTS

ENERGY EXPENDITURES

REPLACEMENTS TO CAPITAL

SUBTOTAL

TOTAL P.V. IIFE-CYCLE COST

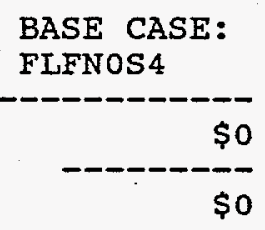

BASE CASE: FLFNOS4

$$
\begin{array}{r}
\$ 1,226 \\
\$ 5,540 \\
\$ 12,292 \\
\hline \$ 19,058 \\
\hline \$ 19,058
\end{array}
$$
ALTERNATIVE:
FLFN7E4

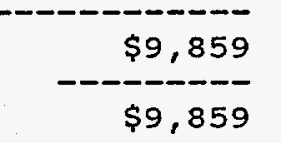

SAVINGS FROM ALT.

$$
\begin{array}{r}
-\$ 9,859 \\
-\$ 9,859 \\
-\$ 660 \\
\$ 1,194 \\
\$ 12,292 \\
\hline \$ 12,825 \\
\hline \$ 2,966
\end{array}
$$$$
\$ 1,887
$$$$
\$ 4,346
$$$$
\$ 0
$$

NET SAVINGS FROM PROJECT FLFN7E4 COMPARED TO PROJECT FLFNOS4

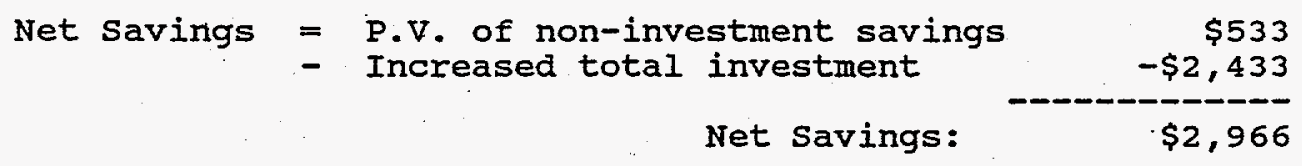

$$
\mathrm{SIR}=\frac{\mathrm{P} \cdot \mathrm{V} . \text { of non-investment savings }}{\text { Increased total investment }}=-0.22
$$


FIGURE B-53.

NIST BLCC: COMPARATIVE ECONOMIC ANALYSIS: FLFOTE4.CMP

BASE CASE: FLFOOS4

ALTERNATIVE: FLFO7E4

PRINCIPAL STUDY PARAMETERS:

ANALYSIS TYPE: Federal Analysis--Energy Conservation Projects STUDY PERIOD: 10 YEARS (1992 THROUGH 2001)

PLAN/CONSTR. PERIOD: I YEARS (1992 THROUGH 1992) OCCUPANCY PERIOD: 9 YEARS (1993 THROUGH 2001)

DISCOUNT RATE: $\quad 4.6 \%$ Real (exclusive of general inflation)

BASE CASE LCC FILE: FLFOOS4.ICC

ALTERNATIVE LCC FILE: FLFO7E4.LCC

COMPARISON OF PRESENT-VALUE COSTS

INITIAL INVESTMENT ITEM(S): CASH REQUIREMENTS AS OF OCCUPANCY

\section{SUBTOTAL}

FUTURE COST ITEMS:

ANNUAI AND NON-AN. RECURRING COSTS

ENERGY EXPENDITURES

REPLACEMENTS TO CAPITAL

SUBTOTAL

TOTAL P.V. IIFE-CYCLE COST

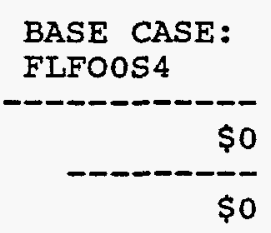

ALTERNATIVE:

FLFO7E4

$\$ 0$

$\$ 0$

$\$ 682$

$\$ 4,214$

$\$ 9,810$

$\$ 14,706$

$\$ 14,706$
$\$ 9,859$

$\$ 9,859$

$\$ 1,049$

$\$ 3,035$

$\$ 0$

$\$ 4,084$

$\$ 13,944$
SAVINGS FROM AIT.

$-\$ 9,859$

$-\$ 9,859$

$-\$ 367$

$\$ 1,179$

$\$ 9,810$

$\$ 10,622$

$\$ 763$

NET SAVINGS FROM PROJECT FLFO7E4 COMPARED TO PROJECT FLFOOS4

Net Savings $=$ P.V. of non-investment savings $\quad \$ 812$

- Increased total investment

Net Savings:

$\$ 763$

SAVINGS-TO-INVESTMENT RATIO (SIR)

FOR PROJECT FLFO7E4 COMPARED TO PROJECT FLFOOS4

$$
\mathrm{SIR}=\frac{\text { P.V. of non-investment savings }}{\text { Increased total investment }}=16.52
$$

B-59 
FIGURE B-54.

NIST BLCC: COMPARATIVE ECONOMIC ANALYSIS: FLFQ7E4.CMP

BASE CASE: FLFQOS4
ALTERNATIVE: FLFQ7E4

PRINCIPAL STUDY PARAMETERS:

ANALYSIS TYPE: Federal Analysis--Energy Conservation Projects

7 YEARS (1992 THROUGH 1998)

PLAN/CONSTR. PERIOD: 1 YEARS (1992 THROUGH 1992)

OCCUPANCY PERIOD: 6 YEARS (1993 THROUGH 1998)

DISCOUNT RATE: $4.6 \%$ Real (exclusive of general inflation)

BASE CASE LCC FILE: FLFQOS4.LCC

ALTERNATIVE LCC FILE: FLFQ7E4.LCC

COMPARISON OF PRESENT-VALUE COSTS

INITIAL INVESTMENT ITEM(S): CASH REQUIREMENTS AS OF OCCUPANCY

SUBTOTAL

FUTURE COST ITEMS:

ANNUAL AND NON-AN. RECURRING COSTS

ENERGY EXPENDITURES

REPLACEMENTS TO CAPITAL

SUBTOTAL

TOTAL P.V. LIFE-CYCLE COST

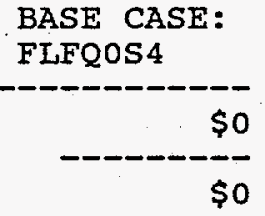

$\$ 682$

$\$ 3,129$

$\$ 6,970$

$-210,781$

$\$ 10,781$

$\$ 10,781$
ALTERNATIVE : FLFQ7E4

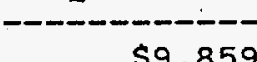

$-$

$\$ 9,859$

$\$ 1,049$

$\$ 2,147$

\$0

$\$ 3,196$

$\$ 13,055$
SAVINGS FROM ALT.

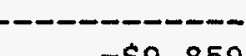

$-\$ 9,859$

$-\$ 9,859$

$-\$ 367$

$\$ 981$

$\$ 6,970$

$\$ 7,584$

$-\$ 2,275$

NET SAVINGS FROM PROJECT FLFQ7E4 COMPARED TO PROJECT FLFQOS4

Net Savings $=$ P.V. of non-investment savings

- Increased total investment

$\$ 2,889$

Net Savings:

$-\$ 2,275$

SAVINGS-TO-INVESTMENT RATIO (SIR)

FOR PROJECT FLFQTE4 COMPARED TO PROJECT FLFQOS 4

$$
\mathrm{SIR}=\frac{\mathrm{P} \cdot \mathrm{V} \cdot \text { of non-investment savings }}{\text { Increased total investment }}=0.21
$$


FIGURE B-55.

NIST BLCC: COMPARATIVE ECONOMIC ANALYSIS: FLFP7E4.CMP

BASE CASE: FLFPOS4

ALTERNATIVE: FLFP7E4

PRINCIPAL STUDY PARAMETERS:

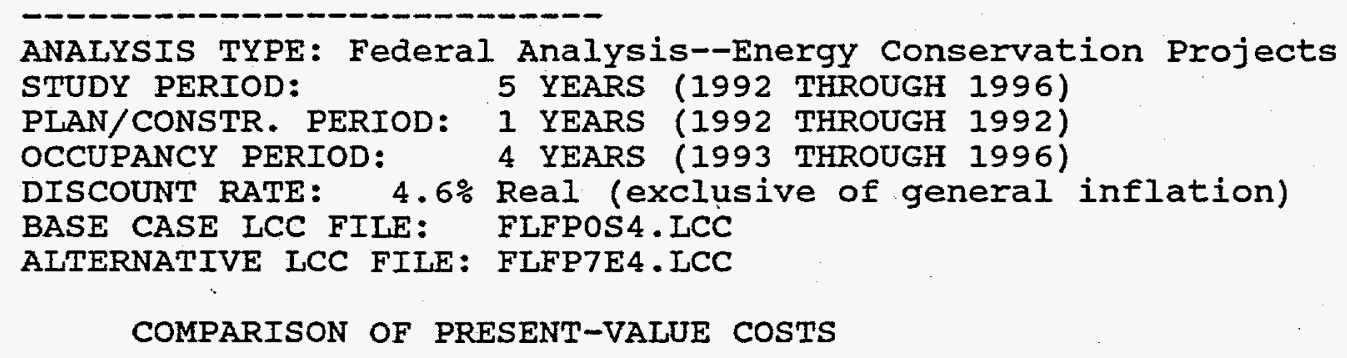

\begin{tabular}{|c|c|c|c|}
\hline & $\begin{array}{l}\text { BASE CASE: } \\
\text { FLFPOS } 4\end{array}$ & $\begin{array}{l}\text { ALTERNATIVE: } \\
\text { FLFP7E4 }\end{array}$ & $\begin{array}{l}\text { SAVINGS } \\
\text { FROM ALT. }\end{array}$ \\
\hline $\begin{array}{l}\text { INITIAL INVESTMENT ITEM(S): } \\
\text { CASH REQUIREMENTS AS OF OCCUPANCY }\end{array}$ & \$o & $\$ 9,859$ & $-\$ 9,859$ \\
\hline $\begin{array}{l}\text { SUBTOTAL } \\
\text { FUTURE COST ITEMS: }\end{array}$ & $\$ 0$ & $\$ 9,859$ & $-\$ 9,859$ \\
\hline $\begin{array}{l}\text { ENERGY EXPENDITURES } \\
\text { REPILACEMENTS TO CAPITAL }\end{array}$ & $\begin{array}{l}\$ 2,239 \\
\$ 3,720\end{array}$ & $\begin{array}{r}\$ 1,500 \\
\$ 0\end{array}$ & $\begin{array}{r}\$ 739 \\
\$ 3,720\end{array}$ \\
\hline SUBTOTAL & $\$ 5,959$ & $\$ 1,500$ & $\$ 4,459$ \\
\hline TOTAL P.V. IIFE-CYCLE COST & $\$ 5,959$ & $\$ 11,359$ & $-\$ 5,401$ \\
\hline
\end{tabular}

NET SAVINGS FROM PROJECT FLFP7E4 COMPARED TO PROJECT FLFPOS4

Net Savings $=$ P.V. of non-investment savings

$\$ 739$

- Increased total investment

$\$ 6,140$

Net Savings:

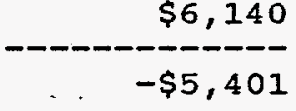

SAVINGS-TO-INVESTMENT RATIO (SIR)

FOR PROJECT FLFPTE4 COMPARED TO PROJECT FLFPOS4

$$
\text { SIR }=\frac{\text { P.V. of non-investment savings }}{\text { Increased total investment }}=0.12
$$


FIGURE B-56.

LIFE CYCLE COST COMPARISON: FLFL7E4.LOW

COMPARATIVE PRESENT-VALUE COSTS OF ALTERNATIVE PROJECTS (Shown in ascending order of initial cost, * = lowest LCC)

\begin{tabular}{|c|c|}
\hline PROJECT & LCC \\
\hline NAME & FIIENAME \\
\hline LFLOS & FIFLOS4 \\
\hline LFL7E & FIFI7E4 \\
\hline
\end{tabular}

INITIAL
COST (PV)
$\$ 9,859$

\begin{tabular}{c} 
LIFE CYCLE \\
COST (PV) \\
\hline$\$ 22,037$ \\
$\$ 19,269 *$
\end{tabular}


FIGURE B-57.

LIFE CYCLE COST COMPARISON: FLFM7EA.LOW

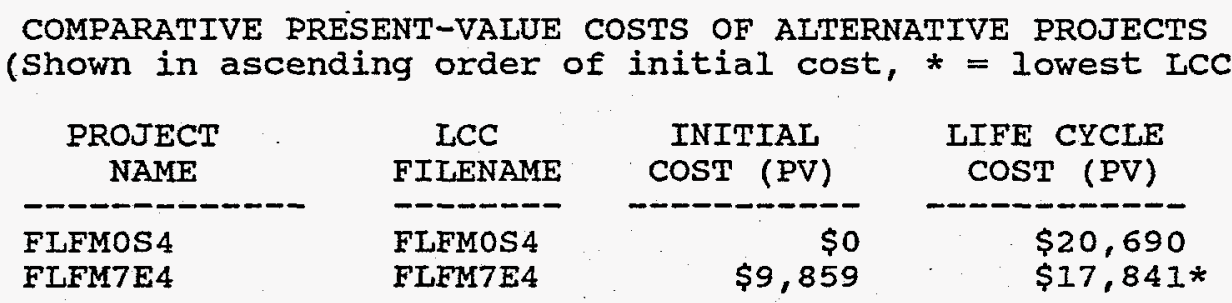


FIGURE B-58.

LIFE CYCLE COST COMPARISON: FLFN7E4.LOW

COMPARATIVE PRESENT-VAIUE COSTS OF ALTERNATIVE PROJECTS
(ShOWn in ascending order of initial cost, $*=$ lowest LCC)
\begin{tabular}{ccrc} 
PROJECT & LCC & INITIAL & LIFE CYCLE \\
NAME & FILENAME & COST (PV) & COST (PV) \\
\hline FLFNOS4 & FLFNOS4 & $\$ 0$ & $\$ 19,058$ \\
FLFN7E4 & FLFN7E4 & $\$ 9,859$ & $\$ 16,092 *$
\end{tabular}


FIGURE B-59.

LIFE CYCLE COST COMPARISON:“FLFOTE4.LOW

COMPARATIVE PRESENT-VALUE COSTS OF ALTERNATIVE PROJECTS (Shown in ascending order of initial cost, * = lowest LCC)

\begin{tabular}{|c|c|}
\hline $\begin{array}{c}\text { PROJECT } \\
\text { NAME }\end{array}$ & $\begin{array}{c}\text { LCC } \\
\text { FILENAMF }\end{array}$ \\
\hline $\begin{array}{l}\text { LFOOS } 4 \\
\text { IFOTE } 4\end{array}$ & $\begin{array}{l}\text { FLFO0S4 } \\
\text { FLFO7E4 }\end{array}$ \\
\hline
\end{tabular}

$\operatorname{INITIAL}$
COST (PV)
$\$ 90,859$

\begin{tabular}{c} 
LIFE CYCLE \\
COST (PV) \\
\hline$\$ 14,706$ \\
$\$ 13,944 *$
\end{tabular}


FIGURE B-60.

LIFE CYCLE COST COMPARISON: FLFP7E4.LOW

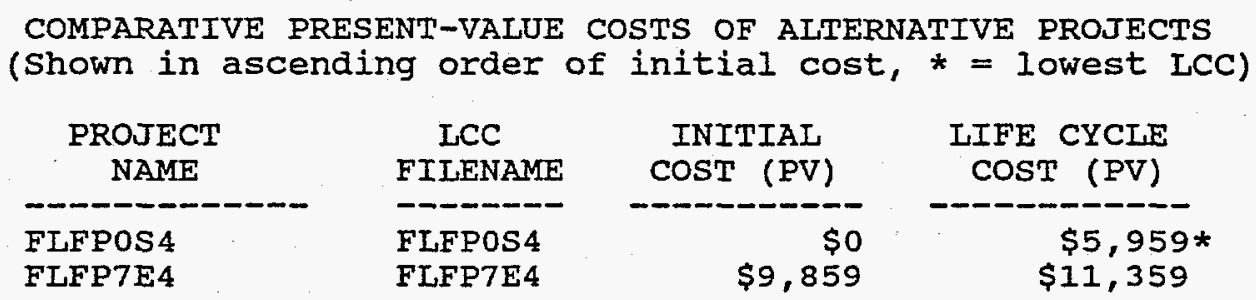


FIGURE B-61.

LIFE CYCLE COST COMPARISON: FLFQ7E4.LOW

COMPARATIVE PRESENT-VALUE COSTS OF ALTERNATIVE PROJECTS (Shown in ascending order of initial cost, * = lowest ICC)

\begin{tabular}{ll}
\multicolumn{1}{c}{ PROJECT } & \multicolumn{1}{c}{ LCC } \\
NAME & FIIENAME \\
\hline FLFQOS4 & FIFOOS4 \\
FLFQ7E4 & FLFQ7E4
\end{tabular}

$\operatorname{INITIAI}$
$\operatorname{COST}(\mathrm{PV})$
$\$ 9,859$

LIFE CYCLE $\operatorname{cosT}(\mathrm{PV})$ $\$ 10,781 *$ $\$ 13,055$ 


\section{APPENDIX C \\ COSTING OF TOTAL FIXTURE CHANGE-OUT}

\section{RADIATION AREA}

\section{CONTAMINATED FIXTURES}

1B2B

Material: $\quad$ (1B2B) Fixtures \& Bulbs

$\$ 36.74$

Protective Equipment (4 sets)

60.00

Labor: $\quad$ Electrical (2 manhours)

118.74

Spill Cleanup (1.5 manhours)

89.06

Radiation Monitor (1 manhour)

72.25

Total

$\$ 376.79 \simeq \$ 377$

2B4B

Material: $\quad$ (2B4B) Fixtures \& Bulbs

$\$ 50.58$

Protective Equipment (4 sets)

Labor: Electrical (2 manhours)

60.00

Spill Cleanup ( 2 manhours)

118.74

Radiation Monitor (2 manhours)

118.74

$\underline{144.50}$

Total -

$\$ 492.56 \simeq \$ 493$

\section{NON-CONTAMINATED FIXTURES}

1B2B

Material: $\quad$ (1B2B) Fixtures \& Bulbs

$\$ 36.74$

Protective Equipment ( 3 sets)

45.00

Labor: $\quad$ Electrical (2 manhours)

118.74

Radiation Monitor (1 manhour)

$\underline{72.25}$

Total

$\$ 272.73 \simeq \$ 273$ 
RADIATION AREA

NON-CONTAMINATED FIXTURES

2B4B

Material: $\quad$ (2B4B) Fixtures \& Bulbs

$\$ 50.58$

Protective Equipment ( 3 sets)

45.00

Labor: $\quad$ Electrical (2 manhours)

118.74

Radiation Monitor (2 manhours)

$\underline{144.50}$

Total

$\$ 358.82 \simeq \$ 359$

NON-RADIATION AREA

\section{CONTAMINATED FIXTURES}

1B2B

Material: $\quad$ (1B2B) Fixtures \& Bulbs

$\$ 36.74$

Protective Equipment (3 sets)

Labor: $\quad$ Electrical (2 manhours)

45.00

Spill Cleanup (1.5 manhours)

118.74

$\underline{89.06}$

Total

$\$ 289.54 \simeq \$ 290$

2B4B

Material: $\quad$ (2B4B) Fixtures \& Bulbs Protective Equipment ( 3 sets)

Labor: $\quad$ Electrical (2 manhours)

Spill Cleanup (2 manhours)

$\$ 50.58$

45.00

118.74

$\underline{118.74}$

Total

$\$ 333.06 \simeq \$ 333$ 
NON-RADIATION AREA

\section{NON-CONTAMINATED FIXTURES}

1B2B

Material: $\quad$ (1B2B) Fixture \& Bulbs

$\$ 36.74^{*}$

Labor: $\quad$ Electrical (2 manhours)

118.74

Total

$\$ 155.50 \simeq \$ 156$

2B4B

Material: $\quad$ (2B4B) Fixture \& Bulbs

$\$ 50.58^{*}$

Labor: $\quad$ Electrical (2 manhours)

$\underline{118.74}$

Total

$\$ 169.32 \simeq \$ 169$

* Keen-Stonco Fixtures with Magnetek Uniform Plus Ballasts

\section{RADIATION AREA}

\begin{tabular}{|c|c|c|c|}
\hline \multicolumn{4}{|c|}{ DISTRIBUTION OF FIUTES. } \\
\hline \multicolumn{2}{|c|}{ RAD AREA } & LEAK & NON-LEAK \\
\hline $1 \mathrm{~B} 2 \mathrm{~B}$ & 2843 & 256 & 2587 \\
\hline 2B4B & 6104 & 549 & 5555 \\
\hline \multicolumn{4}{|l|}{ NON RAO } \\
\hline $1 \mathrm{~B} 2 \mathrm{~B}$ & 6041 & 544 & 5497 \\
\hline $2 \mathrm{~B} 4 \mathrm{~B}$ & 12,972 & 1167 & 11,805 \\
\hline
\end{tabular}


Off-site Disposal of 125 Barrels

(Ballasts \& scrap fixtures that are contaminated 125 @ 1594)

K-1435 TSCA Incinerator 59 Barrels

From Fixtures 20 fix/hour (1400 hrs @ \$59.37/hr)

$\$ 199,250$

531,000

$\underline{83,118}$

Total

$\$ 813,368$

\section{PRICE SUMMARY}

\section{RADIATION AREA}

1B2B

Contaminated: $\quad 286 \times \$ 377=$ $\$ 96,512$

Non-Contaminated: $2587 \times 273=$

2B4B

Contaminated: $\quad 549 \times \$ 493=$ $\$ 270,657$

Non-Contaminated: $5555 \times \$ 359=$

NON-RADIOACTIVE

1B2B

Contaminated: $\quad 544 \times \$ 290=$

Non-Contaminated: $5497 \times 156=$

$\$ 157,760$

857,532

2B4B

Contaminated: $\quad 1167 \times 333=$ $\$ 388,611$

Non-Contaminated: $11,805 \times 169=$ $\underline{1,995,045}$

Total

$\$ 6,466,613$ 
Materials \& Labor

Technical Support (Section 1.6.1.2 of Remediation Plan)

$\$ 6,466,613$

$3,032,908$

Disposal

$\underline{813.368}$

Total

$\$ 10.312 .889$

\section{FIXTURES AS A BASE CASE WITH MAGNETEK UNIT AND BALLAST}

The base case material and labor costs for changing all fixtures as they fail are estimated as follows:

Contaminated Fixtures (1B2B)*

Non-Radiological Area

5117 Fixtures @ \$290/unit

$\$ 1,483,930$

Radiological Area

2409 Fixtures @ \$377/unit

908,193

Contaminated Fixture (2B4B)*

Non-Radiological Area

13,822 Fixtures@ @ $\$ 333$

$4,188,066$

Radiological Area

6552 Fixtures@ @ $\$ 493$

$\underline{\underline{3,230,136}}$

* Keen-Stonco Fixtures with Magnetek Universal Plus Ballasts

Materials \& Labor

$\$ 9,810,325$

Technical Support (Section 1.6.3.3 of Remediation Plan)

$6,903,233$

Disposal (Section 1.6.3.2 of Remediation Plan)

$\underline{1,098.252}$

Total

$\$ 17,811,810$ 
* Magnetek University Plus Ballast

2 Lights (1B2B) $\$ 32.90+2$ lamps @ 3.84

$\$ 36.74$

4 Lights (2B4B) $\quad \$ 42.90+4$ lamps @ 7.68

50.58 